\title{
Cultivo e caracterização de membros do domínio Archaea a partir de sedimentos límnicos do Cerrado.
}

\author{
Deborah Vasconcellos Ambrósio
}

\begin{abstract}
Dissertação apresentada ao Programa de Pós-Graduação em Biologia Molecular do Departamento de Biologia Celular, Instituto de Biologia, Universidade de Brasília para a obtenção do título de Mestre em Biologia Molecular

Orientadora: Dra. Cynthia Maria Kyaw
\end{abstract}




\title{
Cultivo e caracterização de membros do domínio Archaea a partir de sedimentos límnicos do Cerrado.
}

\author{
Deborah Vasconcellos Ambrósio
}

Dissertação aprovada pela banca:

Dra. Cynthia Maria Kyaw (orientadora) (Universidade de Brasília)

Dr. Vicente de Paulo Martins (Universidade de Brasília)

Dra. Lorena da Silveira Derengowski

Brasília, 2016 
Dedico esta dissertação ao meu avô Aércio, cujo carinho e amor eu levo sempre comigo. 


\section{Agradecimentos.}

Em primeiro lugar, preciso agradecer a minha orientadora, Cynthia Kyaw, pois sem ela, eu não teria conhecido o mundo das archaeas e sem a sua dedicação e orientação, este trabalho não teria acontecido. Muito Obrigada por estar sempre presente e pela "mão de mãe" nos momentos em que tudo parecia dar errado!

Quero agradecer os meus pais, Janine e Ivomberg, meus exemplos de vida, que sempre me apoiaram e me incentivaram a seguir a biologia desde pequena. Muito obrigada por não me pedirem para fazer Direito.

Agradeço ao meu amor, Bruno Dourado, meu melhor amigo, pelo apoio e carinho constante durante todas as etapas deste processo. Obrigada por estar sempre do meu lado.

Quero agradecer ao "team Archaea", meus colegas de laboratório, Thiago Rodrigues, Aline Belmok, Isabella Bardela, Letícia Velasco, Letícia Mallman, Ana Luisa e Gabriel por tornar o meu dia-a-dia mais divertido e por todas as contribuições intelectuais, tenho o melhor ambiente de trabalho! Em especial gostaria de agradecer o Thiago Rodrigues por todo o apoio durante a elaboração deste trabalho, principalmente nas análises de bioinformática e a minha companheira de cultivo, Aline Belmok, por compartilhar as dificuldades de cultivar nossas archaeas e por todas as conversas diárias.

Agradeço a professora Heloísa Miranda, pela ajuda na coleta do material para este trabalho e ao professor Ricardo Kruger, pela colaboração com esta pesquisa.

À professora Sônia Báo por disponibilizar os microscópios utilizados neste trabalho e a Ingrid e a Brígida pela ajuda no preparo das amostras para a microscopia

Quero agradecer as minhas queridas pablitas: Laura Berbigier, Kamilla Teixeira, Maria Fernanda e Talita Lima, amigas desde os tempos do colégio que sempre estiveram presentes, mesmo que em pensamento, durante todos os momentos.

Não posso deixar de agradecer as minhas amigas Nathalia Diniz e Bárbara Albuquerque por sempre me ouvirem e me ajudarem nos momentos mais difíceis. Amo vocês!

Por último, gostaria de agradecer o programa de pós-graduação de Biologia MolecularUnB e o CNPq pela oportunidade. 


\section{Lista de Figuras e tabelas.}

Figura 1. Árvore filogenética universal baseada nas comparações entre sequências de rRNA de diversos organismos, na qual é possível observar os três domínios da vida e suas respectivas posições filogenéticas

Figura 2. Árvore filogenética construída a partir de genes de rRNA 16S, demonstrando as relações filogenéticas dos vários filos (aceitos e propostos) de Archaea.

Figura 3. Mapa do Brasil, esquematizando os biomas brasileiros. 17

Figura 4. Foto do córrego Roncador na reserva ecológica do IBGE, local onde foram realizadas as coletas de sedimento. 30

Figura 5. Precipitação total na reserva ecológica do IBGE, no período de julho de 2013 a junho de 2014. 32

Figura 6. Tipos coloniais obtidos em meios sólidos. 35

Figura 7. Novos tipos coloniais obtidos após a adição de $\mathrm{NH}_{4} \mathrm{Cl}$ aos meios. 37

Figura 8. Preparações das colônias selecionadas, coradas pelo método de Gram. a) Placa S 01; b) Placa S 02; c-d) Placa S 5P; e-f) Placa S 06. 40

Figura 9. Preparações coradas pelo método de Gram das colônias da placa S 07........ 41

Figura 10. Preparações coradas pelo método de Gram, de colônias da placa S 09....... 42

Figura 11. Microscopia eletrônica de Varredura de células coletadas das amostras S 01 (a) e S 02 (b).

Figura 12. Microscopia eletrônica de Varredura das amostras S 5P (a e b) e S 06 (c e d). 44

Figura 13. Microscopia eletrônica de Varredura de células coletadas da amostra S 07.45

Figura 14. Microscopia eletrônica de Varredura da amostra S 09. 46

Figura 15. Perfil eletroforético em agarose $1 \%$ corado com brometo de etídio da extração do DNA total do sedimento coletado.

Figura 16. Perfil eletroforético em gel de agarose $1 \%$ corado com brometo de etídio dos produtos de PCR obtidos com os iniciadores relativos ao gene de rRNA 16S de Archaea (a) e amoA (b).

Figura 17. Perfil eletroforético em gel de agarose $1 \%$ corado com brometo de etídio da extração de DNA plasmidial de clones recombinantes contendo segmentos dos genes de (a) rRNA $16 \mathrm{~S}$ e (b) amoA de Archaea. 50

Figura 18. Curvas de rarefação obtidas para a amostra do sedimento do córrego Roncador. 55 
Figura 19. Perfil eletroforético em agarose $1 \%$ corado com Brometo de etídio da extração por fenol/clorofórmio do DNA total das colônias em meio sólido 56

Figura 20. Perfil eletroforético em agarose $1 \%$ corado com Brometo de etídio da extração por fenol/clorofórmio do DNA total das colônias em meio líquido.

Figura 21. Perfil eletroforético em gel agarose $1 \%$ corado com brometo de etídio dos produtos de PCR para o gene 16S de Archaea, a partir do DNA extraído das diferentes colônias. 58

Figura 22. Perfil eletroforético em gel de agarose $1 \%$ corado com brometo de etídio da PCR para o gene $a m o A$, a partir do DNA das colônias. 58

Figura 23. Perfil eletroforético em gel de agarose $1 \%$ corado com brometo de etídio da PCR para o gene de rRNA 16 S de Bacteria. 59

Figura 24. Perfil eletroforético em gel de agarose $1 \%$ corado com brometo de etídio da PCR empregando o DNA extraído das culturas em meio líquido para (a) o gene de rRNA 16S de Archaea, (b) amoA e (c) gene de rRNA 16S de Bacteria. 60

Figura 25. Perfil eletroforético em gel de agarose $1 \%$ corado com brometo de etídio da extração de DNA plasmidial de clones recombinantes aleatórios, contendo parte do gene de rRNA $16 \mathrm{~S}$ de Archaea.

Figura 26. Diagrama de Venn representando as OTUs compartilhadas entre as sequências do gene rRNA $16 \mathrm{~S}$ de Archaea obtidas a partir do cultivo e o sedimento do córrego Roncador. 68

Figura 27. Diagrama de Venn representando as OTUs compartilhadas entre as amostras do gene amoA de Archaea do cultivo em meio sólido e o sedimento do córrego Roncador 71

Figura 28. Árvore filogenética construída pelo método Maximum-likelihood, modelo Tamura-Nei e teste de bootsrap 1000x a partir do fragmento do gene de rRNA 16S das OTUs (97\%) representativas do cultivo e do sedimento alinhadas com archaeas isoladas e não cultivadas dos filos Crenarchaeota, Thaumarchaeota, Bathyarchaeota e Euryarchaeota. 74

Figura 29. Árvore filogenética construída pelo método Maximum-likelihood, modelo Tamura-Nei e teste de bootsrap 1000x a partir do fragmento do gene amoA de Archaea das OTUs (97\%) representativas do cultivo e do sedimento alinhadas com archaeas isoladas do filo Thaumarchaeota e archaeas ainda não cultivadas. 78 
Tabela 1. Pares de iniciadores específicos para os genes 16S de Archaea e Bacteria e

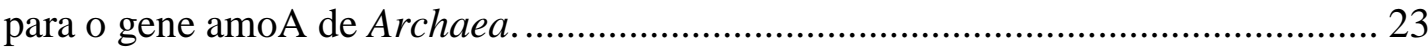

Tabela 2. Programa utilizado com os iniciadores 21f/958r ......................................... 24

Tabela 3. Programa utilizado com os iniciadores 27f/1492r ...................................... 24

Tabela 4. Programa utilizado com os iniciadores arch amoAf/arch amoAr................. 24

Tabela 5. Análise físico-química do sedimento....................................................... 31

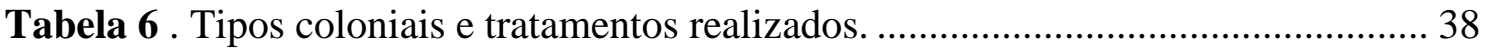

Tabela 7. Classificação taxonômica das sequências do gene de rRNA $16 \mathrm{~S}$ do sedimento, gerada pelo banco de dados Greengenes .................................................. 51

Tabela 8. Número de OTUs observadas (sobs), índices de riqueza (Chao e ACE) e cobertura estimada para a amostra do DNA total do sedimento do córrego roncador em cada um dos índices de dissimilaridade.

Tabela 9. Número de sequências utilizadas nas análises de bioinformática para cada amostra das colônias em meio sólido. 62

Tabela 10. Famílias e Gêneros de bactérias encontradas nas placas do cultivo. 63

Tabela 11. Número de sequências de rRNA $16 \mathrm{~S}$ afiliadas aos diferentes grupos de Archaea para cada placa do cultivo gerada pelo Greengenes

Tabela 12. Diferentes OTUs encontradas com o índice de $97 \%$ de similaridade, alinhadas com o banco de dados Greengenes, para cada amostra do cultivo em meio sólido. 66

Tabela 13. Sequências das OTUs representativas para o gene amoA de Archaea das placas de cultivo e as placas que elas representam. 70 


\section{Sumário}

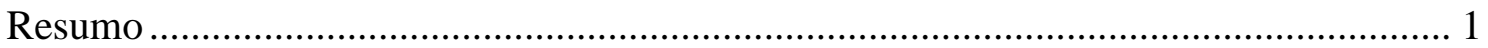

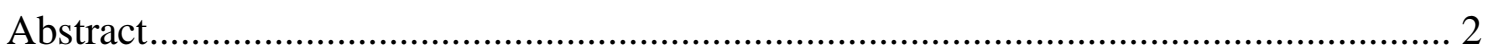

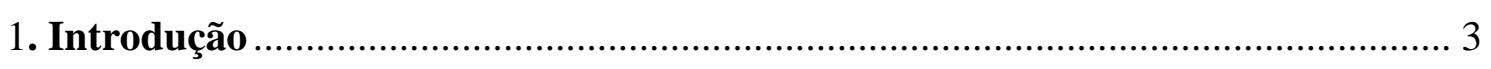

1.1. Filogenia e Taxonomia de procariotos.............................................................. 3

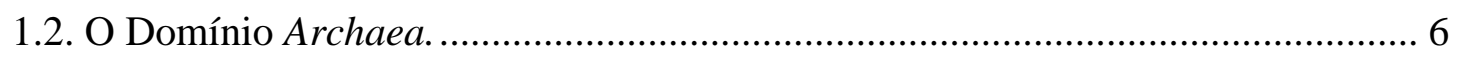

1.3. Distribuição de Archaea. .................................................................................. 7

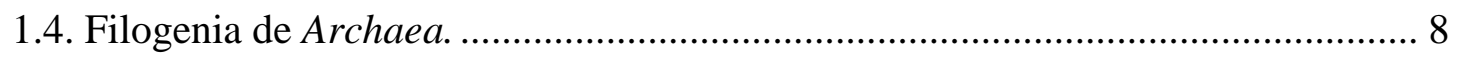

1.5. Archaeas oxidantes de amônia (AOA) ........................................................ 13

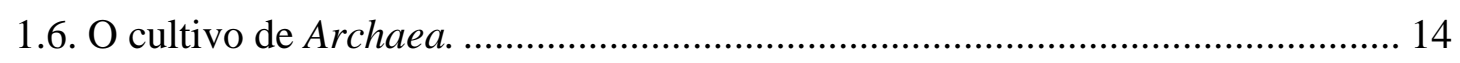

1.7.O Cerrado e as comunidades de Archaea ........................................................... 16

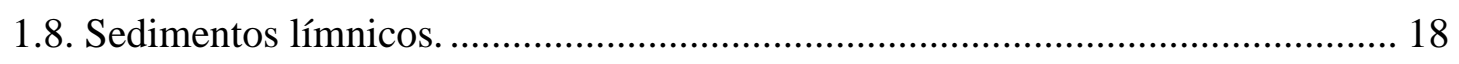

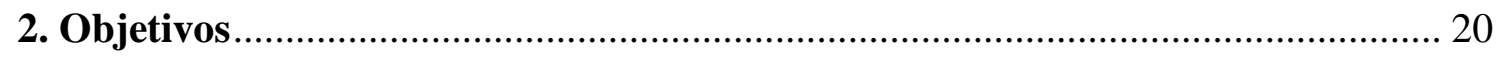

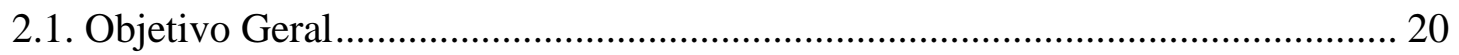

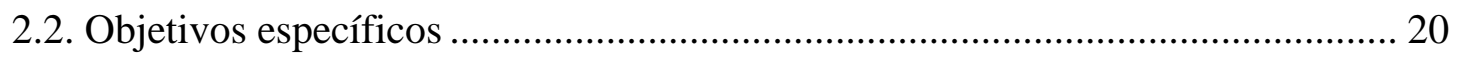

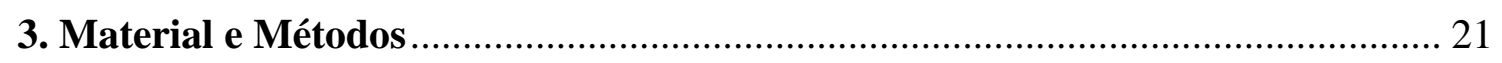

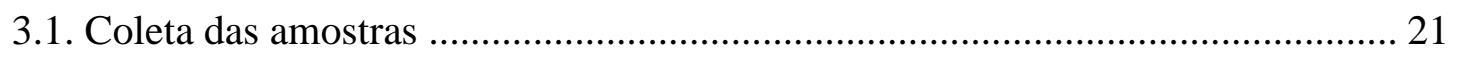

3.2. Preparo do meio e estabelecimento das culturas. ................................................ 21

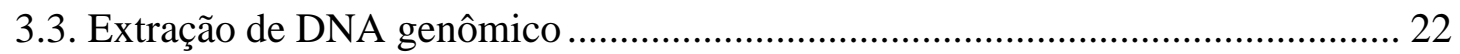

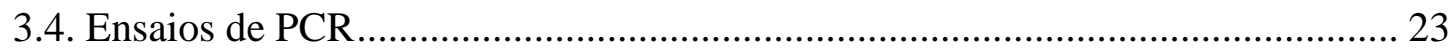

3.5. Purificação dos fragmentos amplificados e confecção dos sistemas de ligação.. 25

3.6. Preparo de Células competentes Escherichia coli DH5a .................................. 25

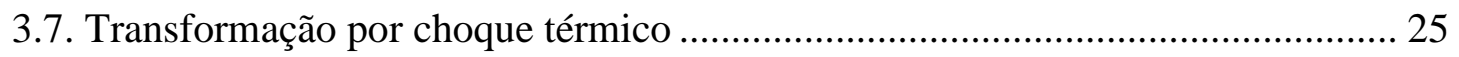

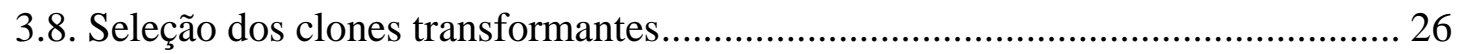

3.9. Extração de DNA plasmidial por lise alcalina .................................................... 26

3.10. Análises de sequenciamento e bioinformática................................................ 27

3.11. Análises morfológicas das células em cultura ............................................... 28

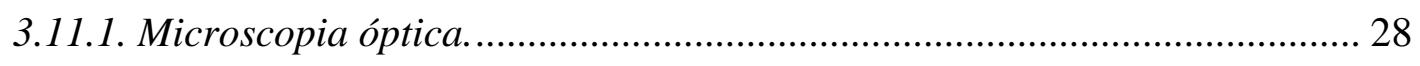

3.11.2. Microscopia eletrônica de Varredura (MEV).......................................... 29

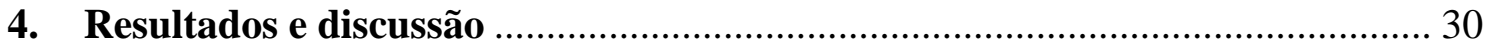

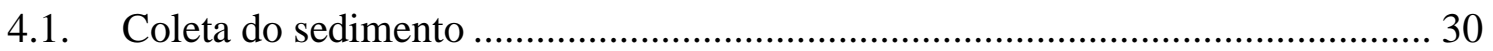

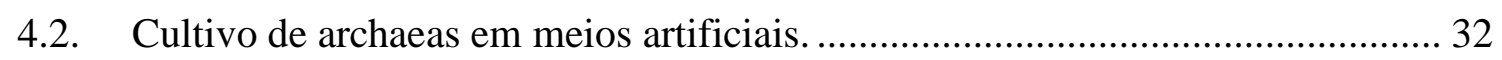

4.2.1. Caracterização morfológica das culturas obtidas....................................... 34 
4.2.2. Coloração de Gram das amostras selecionadas........................................... 38

4.2.3. Microscopia Eletrônica de Varredura (MEV) das colônias selecionadas.... 42

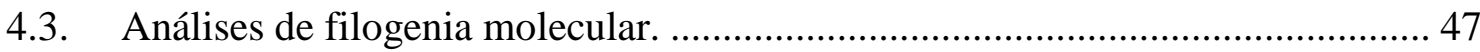

4.3.1. Filogenia molecular do sedimento do córrego Roncador. .............................. 47

4.3.1.1. Extração do DNA genômico total ............................................................ 47

4.3.1.2. Amplificação de fragmentos de DNA dos genes do rRNA $16 \mathrm{~S}$ e da enzima amônia monoxigenase A $(a m o A)$ de Archaea .............................................. 48

4.3.1.3. Transformação células de Escherichia coli DH5 $\alpha$ e seleção de clones

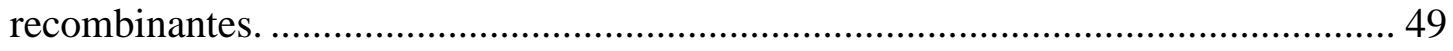

4.3.1.4. Extração de DNA plasmidial.................................................................... 49

4.3.1.5. Sequenciamento automático de DNA..................................................... 50

4.3.1.6. Análises filogenéticas do gene de rRNA 16S do domínio Archaea......... 51

4.3.1.6.1. Classificação taxonômica pelo banco de dados Greengenes................ 51

4.3.1.6.2. Análise de alfa-diversidade ............................................................... 53

4.3.1.7. Análises filogenéticas do gene amoA. ................................................... 55

4.3.2. Filogenia molecular das culturas obtidas........................................................ 56

4.3.2.1. Extração de DNA genômico total............................................................ 56

4.3.2.2. Ensaios de PCR dirigidos aos genes de rRNA $16 \mathrm{~S}$ e da enzima amônia monoxigenase A (amoA) de Archaea. ..................................................................... 57

4.3.2.3. Transformação células de E. coli DH5 $\alpha$ e seleção de clones

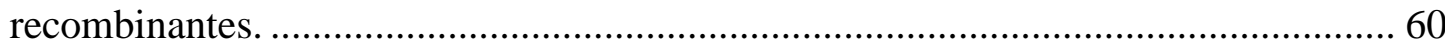

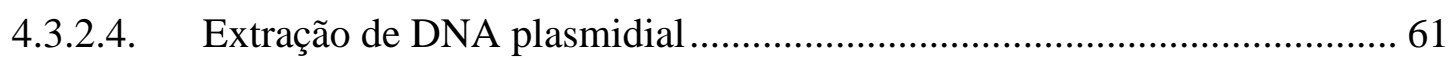

4.3.2.5. Sequenciamento automático de DNA..................................................... 61

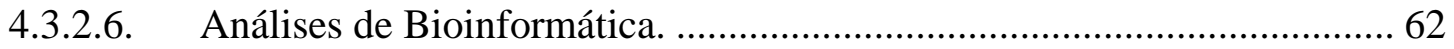

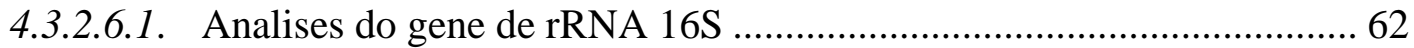

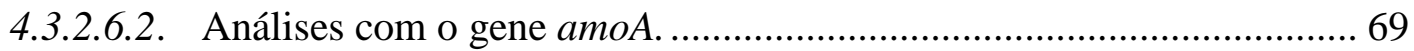

4.3.2.7. Árvores filogenéticas ........................................................................ 71

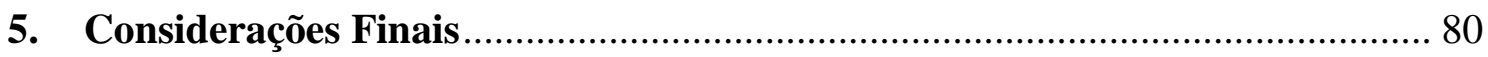

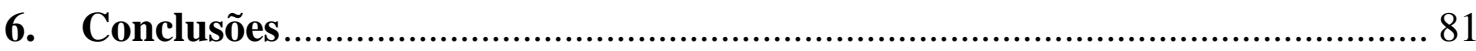

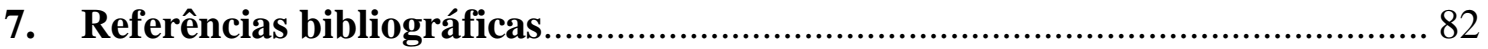




\section{Resumo}

A classificação dos organismos em três domínios, proposta por Woese e colaboradores em 1990, revelou a importância do domínio Archaea e desde então, vários trabalhos têm sido realizados a fim de melhor entender este grupo que se encontra amplamente distribuído no nosso planeta, sendo importante para vários processos ecológicos incluindo os ciclos do Carbono e Nitrogênio. A maior parte do conhecimento deste domínio, incluindo a sua diversidade no bioma Cerrado, está descrita principalmente por métodos independentes de cultivo devido à grande dificuldade de obtenção de culturas em laboratório. Este trabalho propõe a obtenção de culturas laboratoriais de archaeas mesófilas do Cerrado, a partir de sedimentos de um córrego da reserva ecológica do IBGE, localizada em Brasília-DF. Os micro-organismos foram cultivados em meios sólido e líquido, confeccionados a partir da mistura de água e sedimentos deste córrego. O meio de cultura foi adicionado de cloreto de amônio, para favorecer o crescimento de oxidantes de amônia, bem como diferentes agentes antimicrobianos. As amostras foram incubadas em estufa a $28^{\circ} \mathrm{C}$ e analisadas semanalmente quanto ao crescimento, sendo realizados repiques quando necessário. As análises de microscopia revelaram colônias compostas por células diminutas, de diferentes formatos e tamanhos que variam de 0,5 a $3 \mu \mathrm{m}$. Porém, não foi possível relacionar os aspectos morfológicos às archaeas presentes no cultivo. O DNA das colônias obtidas foi submetido a ensaios de PCR com iniciadores específicos para os genes que codificam o rRNA 16S de Archaea e Bacteria e o gene amoA de Archaea, seguido de análises de bioinformática. $\mathrm{O}$ resultado das análises revelou um co-cultivo entre diferentes archaeas dos filos Euryarchaeota, Thaumarchaeota e Bathyarchaeota (Miscelaneous Crenachaeotic Group-MCG) com bactérias de quatro gêneros distintos, pertencentes às famílias Brucellaceae e Burkholderiaceae, sendo a maioria das sequências de Archaea afiliadas ao grupo MCG. As sequências de DNA referentes ao gene amoA, obtidas a partir das

culturas laboratoriais, se afiliaram a um grupo relacionado ao grupo I.1b do filo Thaumarchaeota, não se associando a qualquer representante previamente cultivado. $\mathrm{O}$ sequenciamento dos fragmentos de DNA relativos aos genes de rRNA $16 \mathrm{~S}$ e amoA de Archaea obtidos a partir das amostras do sedimento revelaram a presença de organismos dos mesmos filos encontrados no cultivo. As análises de $\alpha$-diversidade das sequências do gene rRNA $16 \mathrm{~S}$ indicam que a comunidade do córrego Roncador pode ser considerada rica, com uma cobertura estimada de 58,33\% para o nível de espécie. 


\begin{abstract}
The classification of living organisms in three domains, proposed by Woese and collaborators in 1990, revealed the importance of Archaea and since then, a number of studies were developed in order to better understand this widely distributed group, with important roles in many ecological processes including the nitrogen and carbon cycles. The knowledge of this domain, including its diversity in the Cerrado biome, is mostly described by culture independent methods due to the difficulty of obtaining cultures in artificial media. This work describes the cultivation and characterization of Cerrado's mesophilic archaea, from a stream sediment of the IBGE ecological reserve located in Brasília-DF. The microorganisms were cultivated in solid and liquid media prepared with a mixture of stream's sediment and water. In order to improve the growth of ammonia oxidizers, ammonium chloride was added to the media. Antimicrobial agents were also added to prevent bacterial and fungal growth. The samples were incubated at $28^{\circ} \mathrm{C}$ and analyzed weekly for growth. Microscopy analyses showed small cells with different shapes and sizes, from 0,5 to $3 \mu \mathrm{m}$, which were submitted to DNA extraction procedures and subjected to PCR assays with primers directed to the 16S rRNA gene of Archaea and Bacteria, as well as the archaeal amoA gene. The amplicons were submitted to automatic DNA sequencing procedures, and the results revealed that all colonies consisted in co-cultures of different types of archaea from the Euryarchaeota, Thaumarchaeota and Bathyarchaeota (Miscelaneous Crenachaeotic Group-MCG) phyla and Bacteria from four distinct genres of the Brucellaceae and Burkholderiaceae families. The majority of the archaeal 16S rRNA sequences were affiliated to the MGG group. The sequences of the archaeal $a m o A$ gene from the cultures were affiliated to a group associated to the I.1b Thaumarchaeal group, and showed no affiliation to any previously cultured members. Archaeal rRNA $16 \mathrm{~S}$ and amoA gene sequences from the stream sediment were analyzed and the results showed the presence of organisms from the same phyla found in the cultures. $\alpha$-diversity analysess of the rRNA $16 \mathrm{~S}$ sequences showed that the archaeal community of the stream can be considered rich with an estimated coverage of $58,33 \%$ for the species level.
\end{abstract}




\section{Introdução}

\subsection{Filogenia e Taxonomia de procariotos.}

A identificação e classificação dos organismos em grupos distintos sempre foi uma preocupação dos cientistas. Durante muito tempo, características morfológicas foram usadas para agrupar os organismos, desde a dicotomia animal-planta dos antigos naturalistas até a classificação dos cinco reinos proposta por Whittaker, em 1969. Entretanto, a classificação fenotípica encontrava grandes problemas quando o alvo de estudo eram os organismos microscópicos. A falta de registros fosseis, a dificuldade de se identificar características específicas e a sua simplicidade relativa, levava à instabilidade do sistema de classificação dos procariotos. (Rosselló-Mora \& Amann, 2001).

No começo do século $\mathrm{XX}$, o desenvolvimento de técnicas de cultivo permitiu que dados fisiológicos e bioquímicos auxiliassem na classificação dos microrganismos (Schleifer, 2009). Porém, a adição dessas informações não possuía qualquer implicação evolutiva além do produto final da evolução observado nos organismos que vivem atualmente (Owen, 2004). A partir da década de 1960, o uso de técnicas moleculares trouxe uma nova luz para a taxonomia de procariotos. Em 1965, Zuckerkandl e Pauling mostraram que, pelo fato de diferentes códons serem traduzidos em um mesmo resíduo de aminoácido, existiriam diferenças nas sequências dos códons que não apareceriam nas proteínas, tornando o material genético a ferramenta mais apropriada para os estudos evolutivos entre os organismos.

Inicialmente, tal abordagem era realizada por meio da análise do conteúdo de $\mathrm{G}+\mathrm{C}$ do DNA de diferentes organismos. No entanto, essa técnica permitia apenas análises superficiais, pois não levava em consideração a sequência nucleotídica das moléculas de DNA (Rosselló-Mora \& Amann, 2001). Assim, era necessária uma abordagem mais precisa, quando então passou-se a utilizar o método de hibridização DNA-DNA, uma técnica onde duas fitas de DNA de organismos diferentes pareiam-se em regiões onde as sequências nucleotídicas se assemelham, permitindo assim a verificação da similaridade entre estas (Hartford \& Sneath, 1990).

Uma outra abordagem se baseia na comparação de sequências nucleotídicas de diferentes DNAs com aquelas depositadas em banco de dados, onde sequências de DNA previamente descritas são depositadas (Olsen et al., 1986). Alguns genes com alto grau 
de conservação entre os organismos podem ser utilizados como marcadores filogenéticos, tais como genes codificadores de proteínas de ligação ao DNA, de proteínas ribossomais e de amino-acil sintetases, por exemplo (Torvisk \& Ovreas, 2006). Entretanto, o uso de sequencias de RNAs ribossomais (rRNA) ou dos genes que codificam os rRNA, consiste na metodologia mais empregada, existindo atualmente, um grande número de sequências disponíveis em bancos de dados (Rappé \& Giovanonni, 2003).

Os genes do rRNA da subunidade ribossomal menor (16S em procariotos e $18 \mathrm{~S}$ em eucariotos), são considerados ótimos marcadores moleculares, uma vez que são universalmente distribuídos, codificam um produto de função constante entre os organismos e apresentam discretas variações temporais em sua sequência nucleotídica (Fox, 1980). Além disso, tais genes possuem regiões altamente conservadas alternadas com regiões hipervariáveis, possibilitando um bom alinhamento entre as sequências com uma melhor comparação entre elas. Desta forma, tais genes permitem a realização de análises filogenéticas tanto próximas quanto distantes, além de possuirem tamanho mais adequado para esse tipo de análise em relação as outras moléculas de rRNA. (Fox et al., 1977; Olsen, 1986).

Em 1977, George Fox e Carl Woese realizaram trabalhos utilizando uma nova técnica baseada na análise comparativa de fragmentos de rRNA 16S digeridos por endonucleases para estudar as relações filogenéticas entre os microrganismos. Os resultados obtidos em um dos primeiros trabalhos revelaram o potencial desta abordagem na sistemática procariótica ao analisar sequências de seis linhagens de Bacillus spp. e uma linhagem de Sporosarcina spp. (Fox, Pechman \& Woese, 1977). Em seguida, esta técnica foi utilizada para comparar sequências de 10 tipos de microrganismos chamados, à época, de bactérias metanogênicas. Tais análises demonstraram que estes organismos constituíam um grupo filogenético coerente entre si, além de serem diferentes das demais bactérias utilizadas no estudo (Fox et al., 1977). Em um trabalho subsequente, foi realizada a comparação de fragmentos do rRNA de diferentes gêneros de bactérias consideradas comuns, bactérias metanogênicas (16S) e de eucariotos (18S). A partir dos resultados dessas análises, foi observado que as metanogênicas formavam um grupo separado, que não se encontrava afiliado às outras bactérias, ou com os eucariotos e, a partir disso, foi proposto que os organismos procariotos fossem classificados em dois grupos distintos: eubactérias e 
arqueobactérias, sendo o segundo grupo composto pelas bactérias produtoras de metano e o primeiro pelo restante das bactérias até então conhecidas. O termo "arqueobactéria" foi proposto devido ao fato dos organismos metanogênicos apresentarem características consideradas ancestrais (Woese \& Fox, 1977).

Trabalhos posteriores revelaram que o grupo das arqueobactérias consistia não somente das bactérias metanogênicas, mas de organismos com fenótipos diversos que habitavam ambientes extremos (Woese et al., 1978), como halófilas extremas (Magrum et al., 1978), oxidantes de enxofre, termoacidófilas e hipertermófilas (Langworthy et al., 1972; DeRosa et al., 1975). Em 1990, Woese e colaboradores propuseram que os seres vivos fossem divididos filogeneticamente em três domínios, um táxon hierarquicamente superior a reino, denominados: Eukarya, onde se encontrariam todos os organismos eucariotos; Bacteria, as chamadas eubactérias e Archaea, contendo as "arqueobactérias".

Esta divisão dos seres vivos em domínios foi inicialmente discutida, porém, com o aumento do uso de técnicas de análise molecular, esta classificação passou a ter maior aceitação, trazendo uma nova luz aos estudos evolutivos (Wheelis et al., 1992) e um melhor entendimento deste grupo, até então pouco conhecido. O termo "arqueobacteria" foi substituído por Archaea, uma vez que os membros deste domínio representavam organismos distintos das bactérias, e possuíam origem filogenética diferente, provavelmente mais relacionada aos organismos eucariotos (Figura 1). 


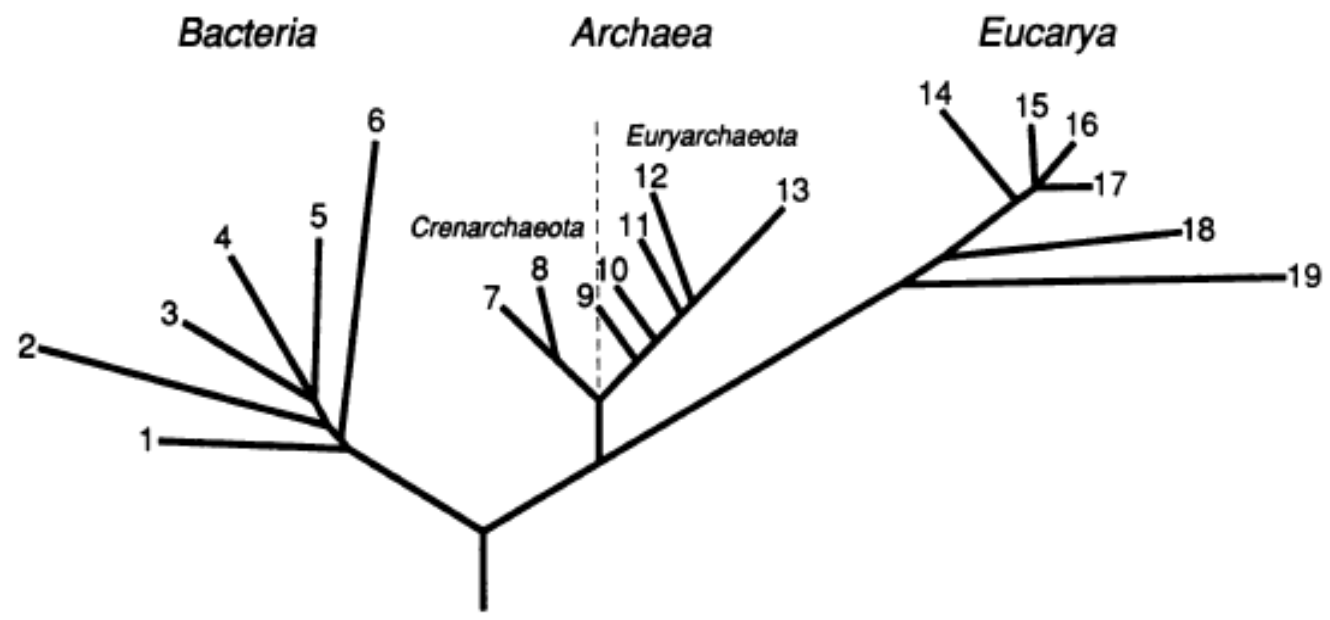

Figura 1. Árvore filogenética universal baseada nas comparações entre sequências de rRNA de diversos organismos, (adaptada de Woese et al., 1990), na qual é possível observar os três domínios da vida e suas respectivas posições filogenéticas. Os números nos ramos correspondem aos grupos dos domínios Bacteria (1- Thermotogales, 2Flavobactérias e organismos relacionados, 3-Cianobactérias, 4- Bactérias púrpuras, 5Gram-positivas e 6- Bactérias verdes e não sulfurosas) Archaea (7- Pyrodictium, 8Thermoproteus, 9- Thermococcales, 10- Methanococcales,11- Methanobacteriales, 12Methanomicrobiales e 13- Halófilos extremos) e Eukarya (14- Animais, 15- Ciliados, 16- Plantas verdes, 17- Fungos, 18- Flagelados, 19- Microsporídeos).

\subsection{O Domínio Archaea.}

Desde a sua proposta em 1977, estudos revelam que as archaeas possuem características semelhantes tanto a procariotos como eucariotos, mas também possuem características próprias. Dentre suas características distintivas, temos a composição de sua membrana citoplasmática, que é formada por cadeias de isopreno ligadas às moléculas de glicerol-1-fosfato por meio de ligações do tipo éter, enquanto bactérias e eucariotos possuem cadeias de ácidos graxos que se ligam ao glicerol-3-fosfato por uma ligação do tipo éster (Kates et al., 1993). Algumas membranas de Archaea organizamse como monocamadas lipídicas, ao invés da tradicional bicamada encontrada nos outros dois domínios (Bullock, 2000). Este tipo de organização é geralmente encontrado em archaeas hipertermófilas, conferindo maior fluidez à membrana desses organismos (DeRosa et al., 1991).

Outra característica peculiar deste domínio consiste na ausência de peptideoglicano em suas paredes celulares, propriedade comum a todas as bactérias. Ao invés disso, as archaeas possuem uma grande variedade de envoltórios celulares, como pseudopeptideoglicano, metanocondroitina, heteropolissacarídeos sulfatados, 
glutaminilglicano e membrana externa (Kandler \& König, 1998; Albers \& Meyer, 2011). Pode existir ainda, associada a outros envoltórios celulares ou como único envoltório, uma camada de proteínas ou glicoproteínas que formam arranjos cristalinos simétricos e com capacidade de auto-organização, denominadas camada S (Konig et al, 2007). Estruturas de superfície de archaeas, como fímbrias e flagelos também apresentam composições diferentes das estruturas de bactérias ( $\mathrm{Ng}$ et al., 2008).

Em relação aos processos celulares, a maquinaria de processamento de informação, como divisão celular, estrutura do DNA, citoesqueleto, transcrição e tradução de archaeas se assemelham mais à maquinaria de células eucarióticas, podendo ser considerada uma versão simplificada desta (Ishino \& Ishino, 2012). A RNA polimerase de Archaea possui estrutura e função semelhantes à RNA polimerase II de eucariotos (Zillig et al., 1979; Stetter et al., 1980), sendo observada nelas, uma resistência a antibióticos que afetam as RNA polimerases de bactérias (Sturm et al., 1980). Porém, esta depende de um menor número de fatores de transcrição (Grohmann \& Werner, 2011). Os ribossomos de Archaea apresentam coeficiente de sedimentação $70 \mathrm{~S}$, como as bactérias, porém com uma composição proteica diferente. O número de fatores traducionais em Archaea é muito maior do que o observado em Bacteria e apresentam um alto grau de homologia com os fatores eucarióticos (Dennis, 1997). Por outro lado, os genes operacionais, envolvidos no metabolismo energético e vias biossintéticas se assemelham mais aos genes bacterianos (Spang et al., 2013).

Em relação ao processo de divisão celular, até o momento foram descritos três mecanismos diferentes: um sistema baseado em proteínas de actina; um sistema do tipo FtsZ, similar ao de bactérias, e um terceiro, homólogo ao sistema ESCRT-III encontrado em eucariotos (Makarova et al., 2010).

\subsection{Distribuição de Archaea.}

Um dos primeiros grupos de archaeas descritas foram as metanogênicas, encontradas em ambientes anaeróbios tais como regiões pantanosas e sedimentos (Barker, 1936). Nesta época, relatos já apontavam para o potencial uso destes organismos no tratamento de esgotos e produção de combustível (Bushwell \& Neave, 1930; Bushwell \& Hatfield, 1930). Posteriormente, outras archaeas passaram e ser detectadas e caracterizadas a partir de ambientes com características extremas como: altas temperaturas (Fiala \& Stetter, 1986; Blöchl et al., 1997); extremos de pH (Darland etal., 1970, Mathrani et al., 1988); ambientes anóxicos (Zeikus, 1977; Balch et al., 
1979) e com alta salinidade (Brisou et al., 1974), o que reforçou a idéia de que tais organismos seriam os possíveis ancestrais das bactérias, por serem encontrados apenas em locais inóspitos, que mimetizavam as possíveis condições ambientais da Terra, quando do surgimento da vida.

Assim, por mais uma década as archaeas foram consideradas organismos procarióticos exclusivamente encontrados em ambientes extremos. No entanto, os trabalhos de DeLong (1992) e Fuhrman (1992) revelaram, por meio de sondas e ensaios de PCR específicos para o domínio Archaea, a presença de sequências de DNA afiliadas ao domínio Archaea em comunidades planctônicas marinhas de ambientes com temperaturas medianas, refutando a ideia de que archaeas eram organismos restritos a ambientes extremos.

Estes dois trabalhos de 1992 abriram as portas para o descobrimento de inúmeras archaeas mesófilas. Em 1994, DeLong e colaboradores identificaram a presença de archaeas nas águas costeiras da Antártida e desde então, muitas pesquisas vêm sendo realizadas, demonstrando a presença de archaeas em uma grande variedade de ambientes como solo, materiais vegetais em decomposição, sedimentos, ecossistemas de agua doce e marinho, plantações e em associação com eucariotos (Bintrim et al., 1997; Leininger et al., 2006; Wucher et al., 2006; Schleper, 2007; Vissers et al, 2009; Manerkar et al., 2008). As archaeas também foram encontradas em várias regiões do corpo humano, tais como pele, cavidade oral e trato digestório ( Belay et al., 1990; Eckburg et al., 2003; Dirdi et al., 2011; Probst et al., 2013).

Hoje em dia, sabe-se que archaeas são organismos ubíquos, com uma ampla distribuição em ambientes considerados normais e extremos (DeLong, 1998; Chaban et al., 2006) e acredita-se que a sua distribuição nestes ambientes se equipare à distribuição bacteriana.

\subsection{Filogenia de Archaea.}

A filogenia de Archaea tem sofrido constantes mudanças, à medida que técnicas independentes de cultivo e sequenciamento vêm revelando sua ampla diversidade e distribuição geográfica. Originalmente, o domínio Archaea foi dividido em dois filos formalmente aceitos até hoje: Euryarchaeota e Crenarchaeota. Euryarchaeota é um filo fenotipicamente heterogêneo, composto por organismos com fisiologias bastante 
distintas, tais como archaeas metanogênicas, termoacidófilas, halófilas, além de algumas hipertermófilas (Forterre et al., 2002). O filo Crenarchaeota continha apenas organismos termófilos e foi considerado inicialmente como um filo mais ancestral e homogêneo (Madigan et al, 2010). Com a disponibilização de novas sequências de genes de rRNA 16S e outros genes marcadores, surgiram propostas de novos filos, alterações dos filos já propostos e também da criação de superfilos. Estes novos grupos vêm sendo amplamente discutidos pela literatura, destacando-se os filos Korarchaeota, Nanoarchaeota, Thaumarchaeota, Aigarchaeota, Bathyarchaeota e Lokiarchaeota, assim como os superfilos TACK e DPANN (Barns et al., 1996; Huber et al., 2002; BrochierArmanet et al., 2008; Nunoura et al., 2011; Guy \& Etema, 2011; Rinke et al., 2013; Meng et al., 2014; Spang et al., 2015).

O Filo Korarchaeota foi proposto em 1996 por Barns e colaboradores a partir do sequenciamento de DNA de amostras de fontes termais do Parque Nacional de Yellowstone, nos Estados Unidos. As análises filogenéticas mostravam que estas sequências de DNA não se relacionavam com os filos Euryarchaeaota e Crenarchaeota, formando um grupo mais basal na árvore filogenética (Auchtung et al., 2006), sendo, por esta razão, incluídas em um novo filo proposto: Korarchaeota. Até o momento não foi descrito o cultivo de qualquer membro deste filo em meios artificiais, porém, recentemente um genoma completo foi obtido de um membro deste grupo, sendo denominado “Candidatus Korarchaeum cryptofilum” (Elkins et al., 2008).

O Filo Nanoarchaeota foi proposto em 2003 por Huber e colaboradores, a partir da caracterização de organismos isolados de uma fenda hidrotermal na Islândia. Estes organismos possuíam um tamanho celular muito pequeno $(400 \mathrm{~nm})$ e encontravam-se sempre associados a uma outra archaea, posteriormente classificada como Ignicoccus hospitalis (Huber et al., 2003). Uma vez que os genes de rRNA 16S deste organismos não eram amplificados por nenhum iniciador considerado universal para Archaea, sugerindo ser um organismo bastante distinto das demais archaeas. Tal organismo foi então denominado de Nanoarchaeum equitans, e passou a ser o membro representante de um novo filo proposto, denominado Nanoarchaeota. Estudos posteriores sugeriram que este grupo não seria um filo, mas sim um grupo de evolução rápida pertencente ao filo Euryarchaeota (Brochier-Armanet et al., 2005).

Como mencionado anteriormente, o descobrimento de archaeas em ambientes não extremos modificou a forma como enxergamos estes organismos, bem como a sua 
classificação. As archaeas mesófilas foram inicialmente classificadas em 3 grupos e afiliadas aos filos Euryarchaota e Crenarchaeota, sendo este último composto pelo grupo I e o primeiro pelos grupos II e III (DeLong, 1998). Entretanto, análises filogenéticas de exemplares do Grupo I, empregando outros genes marcadores, revelaram que este consistia em um grupo irmão, não monofilético, das crenarchaeotas termófilas (Robertson et al., 2005). Assim, foi proposto que estas archaeas de ambientes mesófilos, anteriormente classificadas como Crenarchaeota formariam um novo filo, denominado Thaumarchaeota (Brochier-Armanet et al., 2008). A primeira archaea descrita pertencente a este filo foi um organismo que vivia em simbiose com uma esponja marinha, Cenarchaeum symbiosium (Preston et al., 1996). Com a descoberta de novas espécies em vários ambientes, as thaumarchaeotas passaram a ser classificadas em grupos de isolados de águas, solos, sedimentos e fontes termais (Pester et al., 2011). Uma das características de alguns organismos deste filo consiste na capacidade de oxidar amônia em nitrito, etapa fundamental do ciclo do nitrogênio. A descoberta de archaeas oxidantes de amônia (AOA) revelou a importância destes organismos na ciclagem do nitrogênio do nosso planeta (Spang et al., 2010).

Em 2011, foi descrito o genoma completo de uma archaea isolada a partir de uma mina de ouro que, até então, estava associada ao filo Crenarchaeota (Nunoura et $a l ., 2005)$. Porém, a análise deste genoma revelou que tal archaea apresentava genes que codificavam proteínas associadas ao sistema ubiquitina, de degradação de proteínas, similar ao encontrado em eucariotos. Por esta razão, esta archaea denominada Candidatus Caldiarchaeum subterraneum, foi considerada como membro de um novo filo: Aigarchaeota (Nunoura et al., 2011). Análises recentes sugerem que este organismo pertença ao filo Thaumarchaeota, devido a características deste filo presentes em seu genoma e sua posição em árvores filogenéticas construídas a partir da concatenação de sequências de proteínas ribossomais (Brochier-Armanet et al., 2011).

Trabalhos recentes sugeriram a proposta de classificação de alguns representantes de Archaea em um táxon acima de filo, denominado superfilo. Assim, foram propostos dois superfilos: o primeiro, superfilo TACK, englobaria os filos Thaumarchaeota, Aigarchaeota, Crenarchaeota e Korarchaeota devido a semelhanças filogenéticas (Guy \& Ettema, 2011). O segundo, superfilo DPANN, foi proposto a partir de análises de amostras obtidas com a técnica single cell genomics, sequenciamento de genoma de células únicas, e sequências de genes de rRNA (Rinke et al., 2013). A partir 
desta análise foram propostos quatro novos filos para o domínio Archaea: Diapherotrites, Parvarchaeota, Aenigmarchaeota e Nanohaloarchaeota, que estariam inclusos no superfilo DPANN, juntamente com o filo Nanoarchaeota que, apesar da sua existência ter sido questionada anteriormente, foi mantido neste superfilo.

O filo Crenarchaeota tem sofrido constantes mudanças desde a descoberta de archaeas mesófilas. Além das sequências afiliadas ao grupo I, que posteriormente foram classificadas como o novo filo Thaumarchaeota, outras sequências coletadas de uma grande variedade de ambientes foram agrupadas em um novo grupo deste filo, denominado Miscelaneous Crenarchaeotic Group (MCG) (Inagaki et al., 2003). Este grupo é descrito até o momento apenas por análises do gene de rRNA $16 \mathrm{~S}$ e é considerado amplamente diverso (Kubo et al., 2012). Sequências afiliadas a MCG foram recuperadas a partir de uma diversidade de ambientes tais como fontes termais (Barns et al., 1996), sedimentos marinhos de subsuperfície (Parkes et al., 2005) intestino de cupins (Friedrich et al., 2001), lagos salobros (Hersberger et al., 1996), solos (Huang et al., 2003; Kasai et al., 2005), entre outros. Seu metabolismo ainda não é descrito, mas acredita-se que as archaeas do grupo MCG sejam anaeróbias e heterotróficas (Biddle et al., 2006). Em 2014, Meng e colaboradores realizaram análises filogenéticas de rRNA, proteínas ribossomais e do gene da Topoisomerase IB e, a partir destas análises, foi sugerido que este grupo não pertenceria ao filo Crenarchaeota, sendo, na realidade, uma linhagem irmã de Thaumarchaeota e Aigarchaeota com ramificação profunda na árvore filogenética e provavelmente originada a partir de um ancestral comum. Com isso, foi proposto que MCG seria um novo filo, chamado Bathyarchaeota, posicionado dentro do supoerfilo TACK.

Em maio de 2015, Spang e colaboradores realizaram análises das sequências de DNA obtidas de sedimentos marinhos profundos da crista Gakkel (fenda tectônica também chamada de crista média Ártica) que estariam associadas ao grupo Deep Sea Archaeal Group (DSAG) (Vetriani et al., 1999), um clado abundantemente encontrado em fendas marinhas, associado ao superfilo TACK, com ramificação profunda (Figura 2) e que, até então, não possuia qualquer representante cultivado ou sequenciado. Foram realizadas análises de rRNA $16 \mathrm{~S}$, metagenômica e proteômica com as sequências encontradas e, a partir destas foi montado um genoma de um representante deste grupo, denominado Lokiarchaeum. Com a identificação deste genoma, foi proposto que o 
grupo DSAG passasse a ser considerado um novo filo, Lokiarchaeota (Spang et al., 2015).

Os resultados das análises realizadas com Lokiarchaeum também demonstraram que esta linhagem descoberta possuía uma maior quantidade de características eucarióticas, tais como proteínas de assinatura eucariótica (ESPs), quando comparadas aos achados de outros procariotos até então descritos. Quando sequências de DNA de eucariotos foram incluídas na construção de árvores filogenéticas, estas se posicionavam dentro do filo proposto Lokiarchaeota, sugerindo a possibilidade de o ancestral dos eucariotos ser originário das archaeas (Spang et al., 2015).

As relações filogenéticas de Archaea tem sido alvo de constantes mudanças, à medida que novas sequências são adicionadas aos bancos de dados. Podemos observar esta mudança ao comparar a Figura 1, árvore proposta em 1990, onde só existiam dois filos de Archaea (Woese et al., 1990) com a Figura 2, onde são apresentados novos grupos e filos recentemente propostos (Spang et al., 2015).

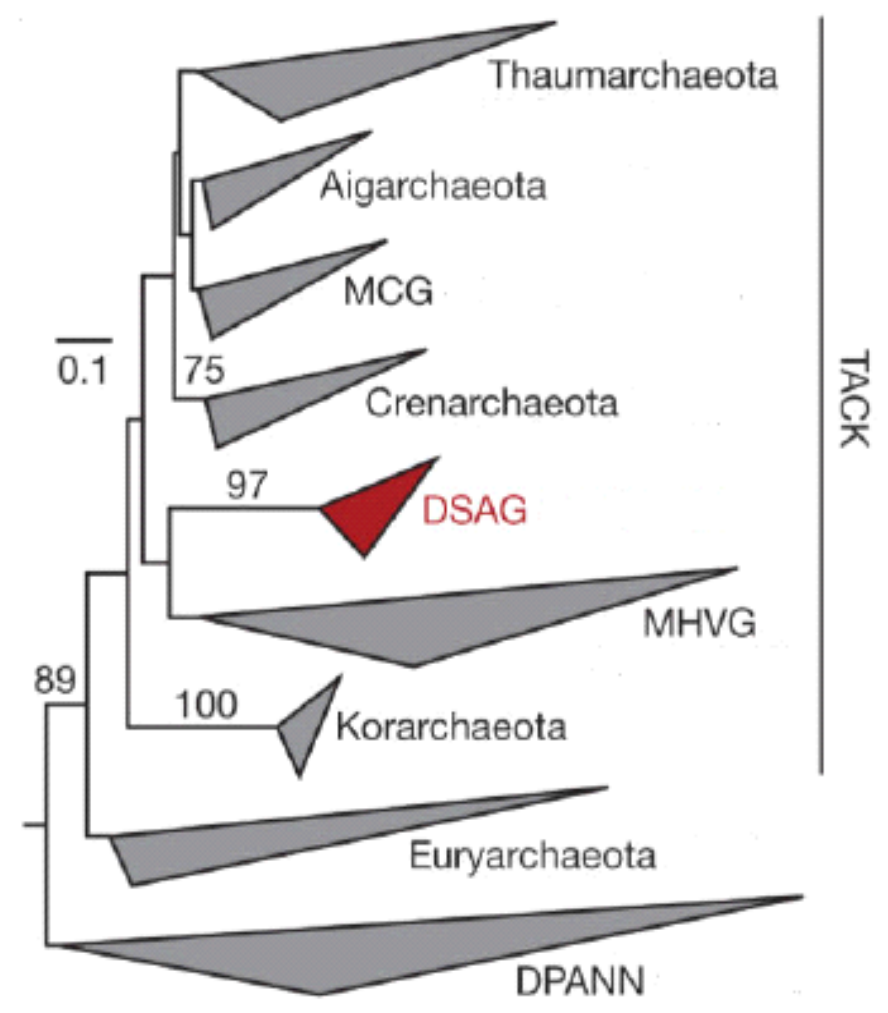

Figura 2. Árvore filogenética construída a partir de genes de rRNA 16S, demonstrando as relações filogenéticas dos vários filos (aceitos e propostos) de Archaea. DSAG: Deep Sea Archaeal Group, filo proposto Lokiarchaeota ; MHVG: Marine Hidrotermal Vent Group (Adaptado de Spang et al., 2015). 


\subsection{Archaeas oxidantes de amônia (AOA).}

O ciclo do nitrogênio é fundamental para a vida no nosso planeta, já que este elemento é necessário a todos os seres vivos. A maioria dos organismos assimila o nitrogênio a partir de moléculas inorgânicas, como a amônia e o nitrato, ou de compostos orgânicos nitrogenados (Cabelló et al., 2004). Estes compostos são escassos no ambiente e dependem de vários processos para serem produzidos a partir da reserva de nitrogênio na atmosfera (Offre et al., 2013). Uma das etapas para a transformação do nitrogênio inorgânico atmosférico em moléculas acessíveis aos organismos é chamada de nitrificação, que consiste na conversão da amônia em nitrato.

A nitrificação ocorre em duas etapas, a oxidação da amônia a nitrito, seguida da oxidação do nitrito a nitrato, realizadas por diferentes tipos de microrganismos: oxidantes de amônia e oxidantes de nitrito (Offre et al., 2013). A oxidação de amônia é considerada o passo limitante da nitrificação, sendo uma reação fundamental no ciclo do nitrogênio (You et al., 2009). Esta reação é mediada pela enzima amônia monoxigenase (Canfield et al., 2010) e até recentemente acreditava-se ser realizada exclusivamente por bactérias. Porém, em 2005 foi descoberto o potencial de oxidação de amônia das archaeas, após o isolamento e sequenciamento do genoma da thaumarchaeota Nitrosopumilus maritimus (Könneke et al., 2005). Desde a sua descoberta, a presença de archaeas oxidantes de amônia (AOAs) vem sendo estudada nos mais diversos ambientes como águas e sedimentos marinhos (Wucher et al., 2006; Beman \& Francis, 2006), ambientes de água doce (Sauder et al., 2011), solos (Ying et al., 2010; Stempfhuber et al., 2014), fontes termais (Weidler et al., 2007) e estações de tratamento de esgoto (Park et al., 2006). Da mesma forma, vários estudos têm analisado sua predominância em relação às bactérias oxidantes de amônia (AOBs) em vários ambientes (Herrmann et al., 2012; Hong et al., 2013), sugerindo que as AOAs sejam organismos com papel relevante no ciclo do nitrogênio.

A oxidação da amônia por AOAs e AOBs apresenta algumas diferenças, tais como a afinidade pelo substrato, onde as archaeas geralmente prevalecem em relação às bactérias quando ambientes oligotróficos são avaliados (Zhalnina et al., 2012). A enzima amônia monooxigenase das AOAs e AOBs são homólogas (Pester et al., 2012) e o gene que codifica a subunidade alfa da enzima para as archaeas e bactérias é considerado um bom marcador filogenético para estudos de diversidade destes 
organismos (Francis et al., 2005; Calvó et al., 2005). O número de estudos que utilizam esse gene para análises fisiológicas e ecológicas de archaeas com o potencial de oxidação de amônia vem aumentando nos últimos anos.

Devido à dificuldade de se obter culturas laboratoriais de membros do filo Thaumarchaeota em laboratório, culturas puras de AOAs ainda são muito raras. Até hoje, foram obtidas apenas três culturas puras de AOAs (Koneke et al., 2005; Tourna et al., 2011; Lehtorvita-Morley et al., 2014), além de algumas culturas de enriquecimento (Lebedeva et al., 2013; Hatzenpocher et al., 2008; Blainey et al., 2011; Jung et al., 2011), o que limita o conhecimento a respeito da ecologia e fisiologia desses organismos. Um maior conhecimento acerca das necessidades nutricionais e físicas destas archaeas certamente contribuirão para a obtenção de culturas de outros membros de Thaumarchaeota no futuro (Stieglmeier et al., 2014).

\subsection{O cultivo de Archaea.}

O uso de técnicas independentes de cultivo trouxe um grande impulso nas áreas de ecologia e filogenia microbianas e também para a biotecnologia, revelando uma grande diversidade de organismos na natureza não cultivados em laboratórios. Arman e colaboradores sugeriram, em 1995, que apenas 0,3\% dos microrganismos de solo e até $0,1 \%$ dos marinhos que eram quantificados por contagem direta eram cultiváveis em meios artificiais. Em 2002, Torsvik e colaboradores sugeriram que apenas $1 \%$ da diversidade microbiana conhecida é representada por organismos cultiváveis.

Devido à dificuldade do cultivo de microrganismos em laboratório, vários estudos de diversidade e filogenia microbianas passaram a utilizar uma abordagem molecular (Pace et al., 1997; Streit \& Shimitz, 2004; Sogin et al., 2006; Delmont et al., 2011), trazendo um grande número de dados inéditos sobre a riqueza de organismos do ambiente. Tais estudos reforçaram a ideia de que os organismos cultivados representam uma parcela ínfima da diversidade de espécies encontradas na natureza (Wintzingerode et al 1997; Handelsman, 2004). Apesar destes estudos revelarem a existência de uma infinidade de funções metabólicas nos microrganismos, os microbiologistas deparam-se com o grande desafio de estabelecer o metabolismo celular, fisiologia e relações ambientais intra- e interespecíficas, devido ao pequeno número de culturas desses organismos em meios artificiais (Kaeberlein et al,. 2002). 
A dificuldade de se obter o cultivo de microrganismos em meios artificiais vem sendo abordada há muito tempo pela comunidade científica. Em 1985, Staley e Konopka revisaram o já conhecido fenômeno chamado "a grande anomalia da contagem em placa", onde se pôde perceber que o número de organismos cultivados em meios sólidos, era muito menor daquele observado em amostras naturais observadas ao microscópio. Este fenômeno pode ser atribuído à dificuldade de se reproduzir as condições naturais do ambiente em meios de cultura artificiais, como diferentes concentrações ou a falta de algum nutriente essencial neste meio (Zengler et al., 2002). Em 2000, Watve e colaboradores relataram que organismos provenientes de ambientes terrestres e aquáticos, são essencialmente oligotróficos e sua transferência para meios de cultura muito ricos em nutrientes, poderia causar um grande impacto metabólico, dificultando seu crescimento. Estudos mostraram que é possível cultivar organismos previamente não cultivados em métodos tradicionais pelo uso de meios de cultura relativamente simples, ou pela modificação na formulação de alguns meios, visando oferecer os componentes químicos do ambiente de onde o organismo foi retirado (Connon \& Giovannoni, 2002).

Um exemplo deste tipo de abordagem consiste na utilização de câmaras de difusão para o cultivo de organismos aquáticos. Esse método, descrito por Kaeberlein e colaboradores em 2002, consiste no inóculo de uma amostra ambiental embebida em ágar, posicionado em uma câmara delimitada por duas membranas de poros com diâmetros específicos, que permitem a passagem de nutrientes mas impedem a passagem de microrganismos. As câmaras são colocadas em um aquário com água e sedimentos do ambiente de onde foi retirada a amostra. Essa técnica permitiu o cultivo de organismos ainda não cultivados e mostrou a importância de se preservar as condições naturais do ambiente para favorecer o cultivo em meios artificiais.

Em relação ao cultivo de archaeas, a maioria dos exemplares cultivados consiste em organismos de natureza extremófila (Balch et al., 1979; Tsao et al., 1994; Pikuta et al., 2007; Luque et al., 2012), por possuírem condições de cultivo mais específicas, com um menor número de organismos que vivem nestes tipos de ambiente, dificultando a contaminação da cultura. Já o cultivo de archaeas mesófilas é mais difícil devido à grande complexidade das comunidades encontradas e a falta de conhecimento sobre seu metabolismo, havendo poucos relatos de sucesso na literatura até hoje (Konneke et al., 2005; Tourna et al., 2011; Kim et al., 2012; Simon et al., 2014; Lehtorvita-Morley et 
al., 2014), sendo grande parte deles de culturas de enriquecimento e co-cultivos entre archaeas e bactérias.

O cultivo de archaeas e suas limitações têm sido amplamente relatados na literatura (Schleper et al., 2005; Auguet et al., 2010; Leigh et al., 2011). Offre e colaboradores citaram que, até novembro de 2012, havia 116 gêneros de Archaea, com 450 espécies validamente descritas e cultivadas, sendo a maioria da diversidade descrita somente por métodos independentes de cultivo que, quando comparadas às amostras cultivadas mais próximas em termos de similaridade, ainda se encontram distantemente relacionadas (Offre et al., 2013). Esse número de organismos cultivados é muito pequeno se comparado às mais de 250.000 sequências de DNA do gene do rRNA 16S de Archaea depositadas nos bancos de dados.

\subsubsection{Cerrado e as comunidades de Archaea.}

O Cerrado é o segundo maior bioma do Brasil (Figura 3), menor apenas que a Floresta Amazônica (Oliveira \& Marquis, 2002), possuindo uma área de cerca de 2 milhões de quilômetros quadrados ( $24 \%$ do território brasileiro), que abrange 11 estados da região central do País (Oliveira-Filho \& Ratter, 2002; Walter et al., 2008). O cerrado possui duas estações bem definidas: a seca, que ocorre de maio a setembro e a chuvosa, no período de outubro a abril e apresenta uma precipitação média anual de $1500 \mathrm{~mm}$ (Klink \& Machado, 2005). Este bioma é do tipo savana e é considerado um hotspot de biodiversidade e de esforços para conservação, devido ao grande número de espécies endêmicas e a sua crescente degradação (Myers et al., 2000). 


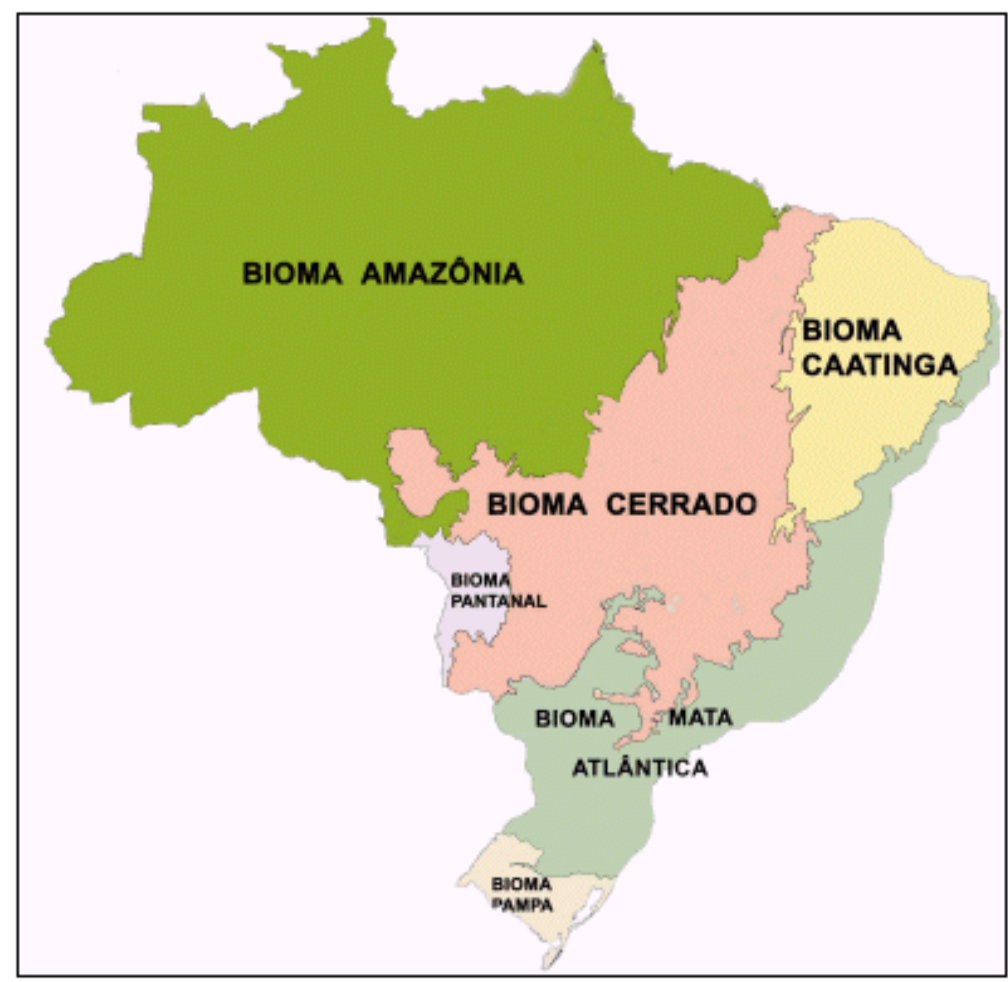

Figura 3. Mapa do Brasil esquematizando os biomas brasileiros. Fonte:(http://www.sobiologia.com.br/conteudos/bio_ecologia/ecologia13.php).

Em relação à ecologia microbiana do Cerrado, são ainda escassos os trabalhos que a descrevem, sendo vários realizados na reserva ecológica do IBGE (Recor), tendo o solo como principal alvo de estudo. Nestes trabalhos foram analisadas as comunidades fúngicas (Castro et al., 2008), bacterianas (Quirino et al., 2009; Araújo et al., 2012; Silva et al., 2012 ) e um conjunto das duas (Bresolin et al., 2010) presentes em solos do Cerrado.

Os estudos sobre a riqueza e diversidade do domínio Archaea no Cerrado, assim como a obtenção de culturas laboratoriais de archaeas mesófilas, consistem em temas centrais desenvolvidos por nosso grupo de pesquisa. Neste sentido, Catão e colaboradores (2013) realizaram a descrição da comunidade de archaeas em solos de Mata de Galeria e Cerrado Denso. Em um estudo mais recente, comunidades de archaeas em solos de Cerrado Sensu scritu submetidos ou não a queimadas periódicas foram descritas, bem como a obtenção de co-culturas de archaeas e bactérias a partir de solos de áreas não submetidas a queimadas (Dias, 2015). Em relação às archaeas de sedimentos lacustres do Cerrado, foi realizado um estudo que descreve a comunidade de archaeas em sedimentos de lagoas durante os períodos de seca e de transição 
seca/chuva, a partir de amostras de sedimento coletadas no parque Sempre Vivas, em Minas Gerais (Rodrigues et al., 2014), onde foi possível visualizar uma maior riqueza e diversidade nos sedimentos coletados na estação de transição seca/chuva, quando comparadas com a estação seca. Além de uma grande quantidade de organismos metanogênicos, seguidos de membros do filo Thaumarchaeota.

Tendo em vista que sedimentos límnicos do Cerrado correspondem a ambientes ainda pouco estudados quanto à riqueza e diversidade de archaeas, estes consistem em um modelo de estudo bastante interessante.

\subsection{Sedimentos límnicos.}

Os sedimentos límnicos geralmente são divididos em duas camadas: a camada recente ou biológica, onde o sedimento está em contato direto com a coluna d'agua e a camada permanente, localizada logo abaixo da recente. A camada recente geralmente apresenta maior quantidade de matéria orgânica, densidade de organismos bentônicos e atividade microbiana (Thomaz, 2011). Por outro lado, a camada permanente é caracterizada por uma condição de completa anaerobiose, baixo teor de matéria orgânica e uma comunidade composta basicamente de microrganismos (Esteves, 2011).

As duas camadas são compostas por duas frações: a primeira, denomimada sólida ou particulada, compreende a principal fonte de energia para os microrganismos e a segunda, fração líquida ou dissolvida, é composta pela água intersticial e apresenta grande importância para o ecossistema aquático devido à grande quantidade de nutrientes que se difundem para os sedimentos (Esteves, 2011). Os sedimentos desempenham importante função na acumulação e reciclagem de nutrientes nos ambientes aquáticos (Straskraba \& Tundisi, 2000). Furtado e colaboradores (2002), observaram que a concentração de nutrientes na fração dissolvida dos sedimentos pode ser maior que aquela encontrada na coluna d'agua, devido à ressuspensão e redeposição ocorridas tanto por perturbações na superfície da água, como por fatores do próprio ambiente aquático (Gloor et al., 1994). As causas destas perturbações podem ser biológicas, como a presença de organismos na região, ou abióticas, como a ocorrência de chuvas, onde o fluxo de nutrientes decorrentes dessas perturbações favorece o crescimento e a atividade metabólica dos microrganismos (Wetzel, 2001). 
Membros de Archaea são comumente encontrados em sedimentos de água doce, especialmente organismos metanogênicos, devido à baixa disponibilidade de oxigênio nas porções mais profundas destes (Lovley et al., 1983; Conrad et al., 1985; Vetriani et al., 1999; Antony et al., 2011; Zhu et al., 2012) Porém, foram também detectados nos sedimentos de água doce, membros do recém proposto filo Bathyarchaeota, o antigo grupo MCG e outros grupos regularmente relacionados a ambientes marinhos, como os Marine Benthic group $B$ e A e Deep Hydrotermal Vent Euryarchaeota Group (DHVEG) (Jiang et al., 2008; Bhattarai et al., 2012; Borrel et al., 2012; Gies et al., 2014), além de membros do filo Thaumarchaeota oxidantes de amônia (Pouliot et al., 2009; Auguet et al., 2011; Auguet et al., 2012; French et al., 2012; Lu et al., 2016). Apesar da função ecológica das AOAs ser bem estabelecida, o entendimento das funções dos outros grupos encontrados em sedimentos límnicos não é bem conhecido, devido à falta de representantes cultivados, dificultando as inferências sobre suas necessidades metabólicas e papel ecológico (Fillol et al., 2015).

Conforme mencionado anteirormente, existem poucos estudos sobre sedimentos límnicos do cerrado. Em 2011, Zardo e colaboradores caracterizaram a composição físico-quimica de sedimentos da micro-bacia do córrego Samambaia no Mato Grosso. Estes autores observaram uma alta acidez nos sedimentos, condição semelhante àquela encontrada em solos do Cerrado. Também foi observado valores de $\mathrm{pH}$ ácidos em um trabalho realizado com sedimentos coletados de lagoas do Parque Nacional Sempre Vivas em Minas Gerais (Rodrigues et al., 2014). Alguns trabalhos ecológicos avaliaram a microfauna eucariótica com papel de bioindicadores de sedimentos do Cerrado (Lorenz-Silva et al., 2005; Guimarães, 2008). Entretanto, o estudo de comunidades procarióticas neste tipo de ambiente ainda se encontra em um estágio bastante inicial.

Tendo em vista que nosso grupo vem desenvolvendo trabalhos visando caracterizar comunidades de Archaea em diferentes ambientes do Cerrado, bem como na obtenção de culturas de Archaea em meios artificiais, este trabalho consiste no estabelecimento de culturas de membros do domínio Archaea presentes em sedimentos límnicos do Cerrado, pelo uso de meio de culturas seletivos que mimetizam as condições naturais do ambiente em que estes organismos se encontram. 


\section{Objetivos}

\subsection{Objetivo Geral}

Obtenção de culturas e caracterização de membros de Archaea de sedimentos límnicos do Cerrado.

\subsection{Objetivos específicos}

- Desenvolvimento de meios de cultura seletivos para o cultivo de Archaeas de sedimentos de água doce.

- Caracterização filogenética das archaeas obtidas em culturas laboratoriais.

- Análises de filogenia molecular da comunidade de archaeas presente no sedimento utilizado para a obtenção das culturas laboratoriais. 


\section{Material e Métodos}

\subsection{Coleta das amostras}

As amostras de sedimentos e água utilizados para a confecção dos meios de cultura e como fonte do inóculo inicial foram coletadas em dois momentos: no dia 02 de setembro de 2013 e 29 de janeiro de 2014, do córrego Roncador na reserva ecológica do Instituto Brasileiro de Geografia e estatística (RECOR-IBGE), localizada na BR-251, a $35 \mathrm{Km}$ ao sul do centro de Brasília. Esta reserva do IBGE está incluída na Área de Proteção Ambiental (APA) Distrital Gama-Cabeça de Veado.

As amostras de água e sedimento foram coletadas próximas à da margem do córrego que, no ponto de coleta, apresenta cerca de 3 metros de largura e aproximadamente $60 \mathrm{~cm}$ de profundidade, em sua área mais central. Para a coleta dos sedimentos foram utilizados tubos de PVC com $10 \mathrm{~cm}$ de comprimento que foram introduzidos na zona superficial (de $1 \mathrm{a} 10 \mathrm{~cm}$ ) do fundo do córrego para a coleta do material e em seguida acondicionados em sacos plásticos e mantidos a $4^{\circ} \mathrm{C}$, até a chegada ao laboratório. Parte da amostra foi estocada a $-20^{\circ} \mathrm{C}$ para a posterior extração de DNA total e parte foi entregue a empresa SOLOQUÍMICA analise de solos LTDA para avaliação de parâmetros físico-químicos. As amostras de água do córrego foram coletadas em garrafas plásticas e estocadas a $4^{\circ} \mathrm{C}$ até o uso.

\subsection{Preparo do meio e estabelecimento das culturas.}

Para o preparo dos meios sólidos, uma alíquota de sedimento (5\%) foi misturada à água do córrego e, em seguida deixada em repouso por alguns minutos para permitir a deposição das partículas maiores. Em seguida, a mistura foi coada em coadores de papel, adicionada de ágar na concentração de $2 \%$ e esterilizada em autoclave. Para a confecção dos meios líquidos foi utilizado o mesmo coado, autoclavado ou não, seguido de um processo de filtração em membranas com poros de 0,22 $\mu \mathrm{m}$ de diâmetro, com o auxílio de uma bomba de vácuo. A fim de tornar o meio seletivo foram utilizados os seguintes agentes antimicrobianos: Ampicilina (150 $\mu \mathrm{g} / \mathrm{ml})$, Estreptomicina $(50 \mu \mathrm{g} / \mathrm{ml})$, Cloranfenicol $(20 \mu \mathrm{g} / \mathrm{ml})$ e Itraconazol $(0.25 \mathrm{mg} / \mathrm{ml})$.

O inóculo inicial consistiu na mistura de sedimento e água do córrego, na concentração de $20 \%$. Para o cultivo em meio sólido, foram inoculados quatro volumes 
diferentes do inóculo $(20 \mu \mathrm{L}, 50 \mu \mathrm{L}, 75 \mu \mathrm{L}$ e $100 \mu \mathrm{L})$ em placas de Petri contendo o meio e agentes antimicrobianos. As placas foram mantidas em estufa com temperatura constante de $28^{\circ} \mathrm{C}$, e repicadas conforme a necessidade. $\mathrm{O}$ cultivo em meios líquidos foi realizado a partir da semeadura do inóculo original (uma alçada de inóculo em $5 \mathrm{~mL}$ de meio) e também a partir das colônias desenvolvidas nos meios sólidos, inoculadas em tubos de vidro e mantidas em estufa a $28^{\circ}$. Além dos agentes antimicrobianos, as culturas líquidas foram suplementadas com $\mathrm{NH}_{4} \mathrm{Cl}$ nas concentrações de $0,1 \mathrm{mM}$ e 0,5 $\mathrm{mM}$, enquanto os meios sólidos foram inicialmente suplementados com $\mathrm{NH}_{4} \mathrm{Cl}$ na concentração de 0,1 mM, aumentando gradualmente até $0,3 \mathrm{mM}$, na tentativa de favorecer o crescimento de organismos oxidantes de amônia. Na tentativa de separar as bactérias presentes na cultura, algumas culturas do meio sólido foram submetidas a um processo de filtração com membranas $0,45 \mu \mathrm{m}$ e transferidas para placas de petri contendo o meio sólido ou tubos de vidro contendo o meio líquido, ambos suplementados com agentes antimicrobianos.

\subsection{Extração de DNA genômico}

O DNA total do sedimento coletado foi extraído com o kit PowerSoil DNA Isolation (MO Bio Laboratories Inc.), de acordo com as instruções do fabricante, com apenas uma modificação: a quantidade de sedimento usado para extração foi $0,5 \mathrm{~g}$ e não 0,25 g como indicado, visto que em outros trabalhos do nosso grupo esta quantidade foi ideal para otimizar a extração.

O DNA total das colônias em cultura sólida e líquida foi extraído pelo método de extração por fenol-clorofórmio. As colônias foram retiradas das placas com alça níquel-cromo e ressuspendidas em tubos tipo eppendorf de $1,5 \mathrm{~mL}$ contendo $472 \mu \mathrm{L}$ de tampão TE (TRIS-HCl 10 mM, EDTA 1 mM, pH 8,0), $8 \mu \mathrm{L}$ de RnaseA 4 mg/mL e 3 $\mu \mathrm{L}$ de Proteinase K $20 \mathrm{mg} / \mathrm{mL}$. Em seguida, foi adicionado $15 \mu \mathrm{L}$ de SDS $20 \%$ e os tubos foram mantidos na estufa por 1 hora a $37^{\circ} \mathrm{C}$. O próximo passo consistiu na adição e homogeneização vigorosa de $500 \mu \mathrm{L}$ de clorofane ( 25 fenol:24 clorofórmio:1 álcool iso-amílico), seguido de centrifugação por 3 minutos a 7000 x $g$, a transferência cuidadosa do sobrenadante para outro tubo e adição e homogeneização de $500 \mu \mathrm{L}$ de clorofil (24 clorofórmio:1 álcool iso-amílico), seguida de nova centrifugação nas mesmas condições, transferência do sobrenadante para tubos novos e a adição de $\mathrm{NaCl}$ $3 \mathrm{M}$ para a concentração final de $0.3 \mathrm{M}$. Os tubos então foram homogeneizados por 
inversão suave, adicionados de 2,5 volumes de etanol $100 \%$ gelado e armazenados por uma noite a $-20^{\circ} \mathrm{C}$. Após este período, os tubos foram centrifugados a $7000 \mathrm{~g}$ por 10 minutos a $4^{\circ} \mathrm{C}$, o sobrenadante descartado e o sedimento ressuspendido em $300 \mu \mathrm{L}$ de etanol 70\%, seguida de uma nova centrifugação nas mesmas condições e descarte do etanol $70 \%$. Os tubos então foram invertidos e mantidos a temperatura ambiente até secar. Para estocar o DNA extraído, o sedimento foi ressuspendido em $90 \mu \mathrm{L} \mathrm{de} \mathrm{H}_{2} \mathrm{O}$ miliQ e mantido a $-20^{\circ} \mathrm{C}$.

O DNA extraído de todas as amostras foi quantificado por meio de eletroforese em gel de agarose a $1 \%$, corado com brometo de etídio $10 \mathrm{mg} / \mathrm{mL}$, empregando-se como referência o marcador de massa molecular High Mass Ladder (Promega).

\subsection{Ensaios de PCR}

O DNA Total obtido pela extração dos sedimentos foi submetido a ensaios de PCR utilizando os iniciadores 21f/958r, específicos para o gene do rRNA 16S de Archaea (DeLong, 1992) e Arch amoaF/Arch amoaR, específico para o gene da subunidade A da enzima amônia monooxigenase de Archaea, amoA (Fancis et. al. 2005).

Para o DNA obtido das colônias, além dos dois iniciadores já mencionados, foi utilizado também o par 27f/1492r (Lane, 1991), específico para o gene rRNA 16S de Bacteria, a fim de analisar a ocorrência de um co-cultivo nas colônias obtidas. As sequências dos iniciadores e o tamanho de fragmento esperados estão apresentados na tabela 1 .

Tabela 1. Pares de iniciadores específicos para os genes 16S de Archaea e Bacteria e para o gene amoA de Archaea.

\begin{tabular}{ccc}
\hline Iniciadores & Sequências & Fragmento esperado \\
\hline Archaea & 5' TTC CGG TTG ATC CYG CCG GA 3' & \\
$(16 \mathrm{~S}) 21 \mathrm{~F}$ & 5' YCC GGC GTT GAM TCC AAT T3' & 937pb \\
$958 \mathrm{R}$ & 5' STAATGGTCTGGCTTAGACG 3' & $635 \mathrm{pb}$ \\
$($ amoA) amoAF & 5' GCGGCCATCCATCTGTATGT 3' & \\
amoAR & 5' AGA GTT TGA TCC TGG CTC AG 3' & $1465 \mathrm{pb}$ \\
Bacteria & 5' GGT TAC CTT GTT ACG ACT T 3' & \\
\hline$(16 \mathrm{~S}) 27 \mathrm{~F}$ & 1492R &
\end{tabular}


As reações foram realizadas em sistemas com volume final de $30 \mu \mathrm{L}$, contendo 5 $\mu \mathrm{L}$ de DNA, em concentrações que variaram de 1 a $50 \mathrm{ng}$. Os demais reagentes foram utilizados nas concentrações a seguir: $1 \mathrm{X}$ de tampão de reação (Invitrogen), 1,5 mM de $\mathrm{MgCl}_{2}, 400 \mathrm{ng} / \mu \mathrm{L}$ de Soroalbumina bovina (BSA), 0,5 $\mu \mathrm{M}$ de cada iniciador (foward e reverse), $200 \mu \mathrm{M}$ de dNTPs e 1,25 U de Taq DNA polimerase (Invitrogen). As concentrações acima citadas foram utilizadas para as reações com todos os pares de iniciadores. Os ensaios de PCR foram realizados em um termociclador (MJ) e as condições utilizadas para cada par de iniciadores são apresentadas nas tabelas 2,3 e 4 .

Tabela 2. Programa utilizado com os iniciadores 21f/958r

1 Desnaturação inicial a $94^{\circ} \mathrm{C} / 1 \mathrm{~min}$.

2 Desnaturação a $94^{\circ} \mathrm{C} / 1 \mathrm{~min}$.

3 Anelamento a $55^{\circ} \mathrm{C} / 1 \mathrm{~min}$

4 Extensão a $72^{\circ} \mathrm{C} / 1 \mathrm{~min}$

5 Repetir passos 2 a $4-29$ vezes

6 Extensão final a $72^{\circ} \mathrm{C} / 5 \mathrm{~min}$

$7 \quad$ Manutenção a $4^{\circ} \mathrm{C}$
Tabela 3. Programa utilizado com os iniciadores $27 \mathrm{f} / 1492 \mathrm{r}$

1 Desnaturação inicial a $94^{\circ} \mathrm{C} / 5 \mathrm{~min}$.

2 Desnaturação a $94^{\circ} \mathrm{C} / 1 \mathrm{~min}$.

3 Anelamento a $55^{\circ} \mathrm{C} / 1 \mathrm{~min}$

4 Extensão a $72^{\circ} \mathrm{C} / 2 \mathrm{~min}$

5 Repetir passos 2 a $4-29$ vezes

6 Extensão final a $72^{\circ} \mathrm{C} / 10 \mathrm{~min}$

7 Manutenção a $4^{\circ} \mathrm{C}$

Tabela 4. Programa utilizado com os iniciadores arch amoAf/arch amoAr

\begin{tabular}{lc}
1 & Desnaturação inicial a $94^{\circ} \mathrm{C} / 5 \mathrm{~min}$. \\
2 & Desnaturação a $95^{\circ} \mathrm{C} / 1 \mathrm{~min}$. \\
3 & Anelamento a $53^{\circ} \mathrm{C} / 1 \mathrm{~min}$ \\
4 & Extensão a $72^{\circ} \mathrm{C} / 1 \mathrm{~min} 30 \mathrm{seg}$ \\
5 & Repetir passos 2 a $4-29$ vezes \\
6 & Extensão final a $72^{\circ} \mathrm{C} / 10 \mathrm{~min}$ \\
7 & Manutenção a $4^{\circ} \mathrm{C}$ \\
\hline
\end{tabular}

Em todos os ensaios foi utilizado um controle negativo, que consistia na substituição do DNA por $\mathrm{H}_{2} \mathrm{O}$ MilliQ. Nos ensaios realizados com o DNA das colônias, foi usado um controle positivo (DNA de Haloferax volcanii para o par de iniciadores 21f/958r, Salmonella sp. para o par 27f/1492r e DNA total dos sedimentos para amoAf/amoAr). Os resultados dos ensaios foram analisados por meio de eletroforese 
em gel de agarose $1 \%$, corado com brometo de etídio $10 \mathrm{mg} / \mathrm{ml}$, usando como referência o marcador de massa molecular $1 \mathrm{~Kb}$ Plus DNA Ladder (Invitrogen).

\subsection{Purificação dos fragmentos amplificados e confecção dos sistemas de ligação}

Os produtos de todas as reações de PCR foram purificados com o kit GeneJET PCR Purification (Thermo Scientific), conforme instruções do fabricante, e analisados por eletroforese em gel de agarose $1 \%$. Os fragmentos obtidos nas reações de PCR com o DNA extraído das colônias para os genes amoA e 16S de Bacteria foram submetidos ao sequenciamento logo após a purificação, sem qualquer etapa de clonagem.

Os fragmentos obtidos com os iniciadores para o gene $a m o A$ a partir do DNA total do sedimento e para o gene 16S de Archaea, tanto do DNA total do sedimento quanto das colônias, foram ligados ao vetor pGEM-T Easy® (Promega), na proporção 3:1 de inserto:vetor, segundo instruções do fabricante, mantidos por $1 \mathrm{~h}$ em temperatura ambiente e armazenados a $4^{\circ} \mathrm{C}$ por uma noite.

\subsection{Preparo de Células competentes Escherichia coli DH5a.}

As células de $E$. coli DH5a foram inoculadas em $5 \mathrm{~mL}$ de meio Luria Bertani (LB) e incubadas a $37^{\circ} \mathrm{C}$, sem agitação, por 16-24 horas. Em seguida, $300 \mu \mathrm{L}$ desta cultura foram inoculados em $30 \mathrm{~mL}$ de meio LB e incubados sob agitação de 200rpm a $37^{\circ} \mathrm{C}$, até a cultura atingir a densidade óptica $\left(\mathrm{OD}_{600)}\right.$ de 0,2 a 0,3 . A cultura foi transferida para tubos de plástico e centrifugada a $4000 \mathrm{~g}$ por 10 minutos a $4^{\circ} \mathrm{C}$. $\mathrm{O}$ sobrenadante foi descartado e o sedimento ressuspendido em $15 \mathrm{~mL}$ de solução de cloreto de cálcio $100 \mathrm{mM}$ fria. Os tubos foram incubados no gelo por 20-30 minutos e as então centrifugados a $2000 \mathrm{x}$ g por 10 minutos a $4^{\circ} \mathrm{C}$, sendo o sobrenadante descartado, as células ressuspendidas em $1 \mathrm{~mL}$ de cloreto de cálcio e mantidas no gelo por 30 minutos.

\subsection{Transformação por choque térmico.}

Alíquotas de $100 \mu \mathrm{L}$ das células competentes foram transferidas para tubos de hemólise, aos quais foram adicionados $5 \mu \mathrm{L}$ de cada sistema de ligação. Os tubos foram incubados em gelo por 30 minutos, seguido de choque térmico em banho-Maria a $37^{\circ} \mathrm{C}$ 
por 5 minutos. Em seguida, foi adicionado $1 \mathrm{~mL}$ de meio LB a cada tubo e os sistemas incubados em estufa a $37^{\circ} \mathrm{C}$ por 1 hora. Após esse período, alíquotas variáveis das células foram semeadas em placas de Petri de plástico contendo ágar LB adicionado de Xgal 0,00625\%, IPTG 0,5 mM e ampicilina $150 \mu \mathrm{g} / \mathrm{mL}$, com auxílio de perolas de vidro. As placas foram mantidas por uma noite na estufa a $37^{\circ} \mathrm{C}$.

\subsection{Seleção dos clones transformantes.}

As colônias brancas das placas da transformação foram selecionadas com o uso de palitos de madeira estéreis e inoculadas individualmente em tubos de vidro contendo $5 \mathrm{~mL}$ de meio LB líquido adicionado de $5 \mu \mathrm{L}$ de ampicilina $150 \mu \mathrm{g} / \mathrm{mL}$. Os tubos foram mantidos em estufa a $37^{\circ} \mathrm{C}$ por $16-24$ horas, quando parte da cultura foi transferida para tubos tipo eppendorf contendo glicerol $70 \%$, a fim de se obter um estoque de células em glicerol com concentração final de $35 \%$. O estoque foi mantido a $-20^{\circ} \mathrm{C}$.

\subsection{Extração de DNA plasmidial por lise alcalina.}

Para fazer a extração do DNA plasmidial dos clones recombinantes, $50 \mu \mathrm{L}$ das células estocadas em glicerol foram inoculadas em tubos de vidro contendo $5 \mathrm{~mL}$ de meio LB adicionado de ampicilina $150 \mu \mathrm{g} / \mathrm{mL}$, e mantidos por uma noite a $37^{\circ} \mathrm{C} \mathrm{sem}$ agitação. Após este período, as culturas foram transferidas para tubos tipo eppendorf de $1,5 \mathrm{~mL}$ e centrifugadas a $6000 \mathrm{x}$ g por 5 minutos e o sobrenadante descartado. Este último passo foi repetido para aumentar a quantidade de células. Após as duas centrifugações, o sedimento foi ressuspendido em $100 \mu \mathrm{L}$ de solução I (glicose $50 \mathrm{mM}$, Tris-HCl $25 \mathrm{mM}$ e EDTA $10 \mathrm{mM}, \mathrm{pH} \mathrm{8,0)} \mathrm{e} \mathrm{mantido} \mathrm{a} \mathrm{temperatura} \mathrm{ambiente} \mathrm{por} 5$ minutos. Em seguida, foram adicionados $200 \mu \mathrm{L}$ de solução II (SDS 1\% e NaOH 0,2 M), preparada pouco antes do uso, os tubos foram homogeneizados gentilmente e incubados em gelo por 5 minutos. Foram adicionados então $150 \mu \mathrm{L}$ de solução III (Ácido acético glacial $2 \mathrm{M}$ e acetato de potássio $3 \mathrm{M}$ ), homogeneizado vigorosamente, sendo os sistemas novamente incubados em gelo por 5 minutos. Os tubos foram centrifugados a $12000 \mathrm{x} g$ durante 5 minutos a $4^{\circ} \mathrm{C}$ e o sobrenadante transferido para um tubo novo, adicionado de $5 \mu \mathrm{L}$ de RnaseA $10 \mathrm{mg} / \mathrm{mL}$ e mantidos a $37^{\circ} \mathrm{C}$ na estufa por 1 hora. 
A partir desta etapa os procedimentos subsequentes foram semelhantes àqueles adotados na extração de DNA total das colônias. Cada sistema foi adicionado de 1 volume de clorofane, homogeneizado vigorosamente e centrifugado a $7000 \mathrm{~g}$ por 3 minutos. O sobrenadante foi transferido para um novo tubo e adicionou-se clorofil, seguido de homogeneização e centrifugação nas mesmas condições descritas na etapa anterior. O sobrenadante foi transferido para um novo tubo, adicionado de 2,5 volumes de etanol $100 \%$ gelado e armazenados por uma noite a $-20^{\circ} \mathrm{C}$. Após este tempo, os tubos foram centrifugados a $12000 \mathrm{~g}$ por 10 minutos a $4^{\circ} \mathrm{C}$ e o sobrenadante descartado. $\mathrm{O}$ sedimento foi lavado com $300 \mu \mathrm{L}$ de etanol $70 \%$, sendo em seguida centrifugado nas mesmas condições. Novamente o sobrenadante foi descartado e os tubos invertidos e mantidos à temperatura ambiente, até a secagem completa do sedimento, que foi posteriormente ressuspenso em $50 \mu \mathrm{L}$ de $\mathrm{H}_{2} \mathrm{O}$ MilliQ e estocado a $-20^{\circ} \mathrm{C}$.

A qualidade da extração e a concentração do DNA plasmidial obtido foram analisadas por eletroforese em gel de agarose $1 \%$, utilizando-se como referência o marcador de massa molecular High Mass (Invitrogen).

\subsection{Análises de sequenciamento e bioinformática}

Os amplicons de PCR para o gene rRNA 16S das colônias obtidos em 2014 foram sequenciados por colaboradores na Universidade Católica de Brasília. O restante dos amplicons e o DNA plasmidial recombinante contendo os fragmentos de interesse foram sequenciados parte pelo Laboratório de Biologia Molecular da Universidade de Brasília, no sequenciador automático ABI3730 da Applied Biosystems, e parte pela empresa Macrogen. Foram utilizados no sequenciamento os iniciadores 21F, 27F ou ArchamoAF de acordo com o iniciador utilizado na reação de PCR. As sequências de DNA obtidas foram analisadas quanto à qualidade pelo algoritmo PHRED (Ewing et al., 1998), através da ferramenta Electropherogram quality analysis disponível na página da EMBRAPA: http://asparagin.cenargen.embrapa.br/phph/. Foram selecionadas as sequências que apresentaram o valor de PHRED superior a 20 para mais de 250 nucleotídeos. Sequências com valores inferiores foram descartadas.

As sequências correspondentes aos genes de rRNA16S e de amoA obtidas tanto do cultivo quanto da amostra do sedimento foram submetidas a alinhamentos múltiplos, utilizando-se o programa ClustalX (Larkin et al., 2007) e o resultado do alinhamento foi editado manualmente com o auxílio do programa BioEdit 
(http://www.mbio.ncsu.edu/bioedit/bioedit.html). Sequências de difícil edição ou muito curtas foram eliminadas. As sequências do gene de rRNA $16 \mathrm{~S}$ obtidas foram submetidas a análises comparativas no banco de dados taxonômico do Greengenes (DeSantis et al., 2006), através do programa Mothur (Schloss et al., 2009). O programa Mothur também foi utilizado para: Análises de obtenção das OTUs representativas; obtenção dos índices de riquieza Chao e ACE; cobertura estimada da amostragem; confecção de curvas de rarefação e diagramas de Venn. Foram empregados os coeficientes de similaridade $80 \%$ para o nível taxonômico de filo, 90\% para classe, 95\% para gênero e 97\% para espécie para as sequências relativas ao gene rRNA $16 \mathrm{~S}$ e para o gene amoA, foram realizadas analises de obtenção do número de OTUs representativas, cobertura da amostragem e diagramas de Venn com coeficiente de similaridade de $97 \%$.

As árvores filogenéticas com as sequências do gene rRNA $16 \mathrm{~S}$ e amoA foram construídas com o programa MEGA5 (Tamura et al., 2011), pelo método de Maximum likelihood, com o modelo Tamura-Nei e teste de bootstrap de 1000 repetições (Felsenstein, 1985). Sequências representativas a nível de espécie (3\%), obtidas com o auxílio do programa Mothur, foram comparadas a sequências disponíveis no banco de dados do NCBI (US National Center of Biotechnology Informantion) por meio da ferramenta BLAST (Altschul et al., 1990) e aquelas que apresentaram os mais altos valores de similaridade foram incluídas nas árvores.

\subsection{Análises morfológicas das células em cultura}

\subsubsection{Microscopia óptica.}

Após o estabelecimento da cultura, foram preparados esfregaços das colônias em lâminas histológicas de vidro, com auxílio de uma alça niquel-cromo e fixados ao fogo. Esses esfregaços foram corados pelo o método de Gram, conforme protocolo padrão: aplicação de cristal violeta por 1 minuto, lavagem com água destilada, aplicação de lugol por 1 minuto, nova lavagem com água destilada; aplicação de etanol absoluto por 10-15 segundos, lavagem em água destilada e finalmente, aplicação de fucsina por 1-2 minutos e lavagem final com água destilada. Todas as lâminas foram observadas em microscópio óptico, em aumento de 1000 x. 


\subsubsection{Microscopia eletrônica de Varredura (MEV).}

As análises das amostras, bem como seu preparo, foram realizadas no Laboratório de Microscopia da Universidade de Brasília, coordenado pela professora Sônia Nair Báo. As culturas foram raspadas das placas, ressuspendidas em tampão PBS 1X e fixadas com o fixador Karnovsky 0,1 M (paraformaildeído 2\%, Glutaraldeído 2\%, sacarose $1 \%$, cloreto de cálcio $0,005 \mathrm{M}$ em meio tamponado por cacodilato de sódio 0,1 M) por 4 horas em temperatura ambiente. As amostras fixadas foram lavadas com tampão cacodilato de sódio $0,1 \mathrm{M}$ e depositadas em lamínulas contendo poli-L-lisina. Foi realizada a pós-fixação com tetróxido de ósmio $1 \%$ por 30 minutos. Após a lavagem das lamínulas com água destilada foi feita a desidratação gradual com acetona 50, 70, 90 e 100\%, ficando 5 minutos em cada concentração. Foi feita a secagem ao ponto crítico de $\mathrm{CO}_{2}$ no equipamento Balzers CPD030 (Balzers Union AG) e a metalização com vapores de ouro no metalizador Balzers SCD050. Após o preparo, as amostras foram analisadas no microscópio eletrônico de varredura JEOL Ltd. a 15,0 kV. 


\section{Resultados e discussão}

\subsection{Coleta do sedimento}

Os sedimentos e água do córrego utilizados para as análises moleculares, inóculo inicial e confecção dos meios de cultura foram coletadas em dois momentos: primeiramente no dia 02 de setembro de 2013, um período de transição entre as estações seca e chuvosa e no dia 29 de janeiro de 2014, estação chuvosa (Figura 4). Todos os sedimentos foram coletados em uma profundidade de até $10 \mathrm{~cm}$, sendo então considerados sedimentos da camada recente de deposição (Thomaz, 2001).

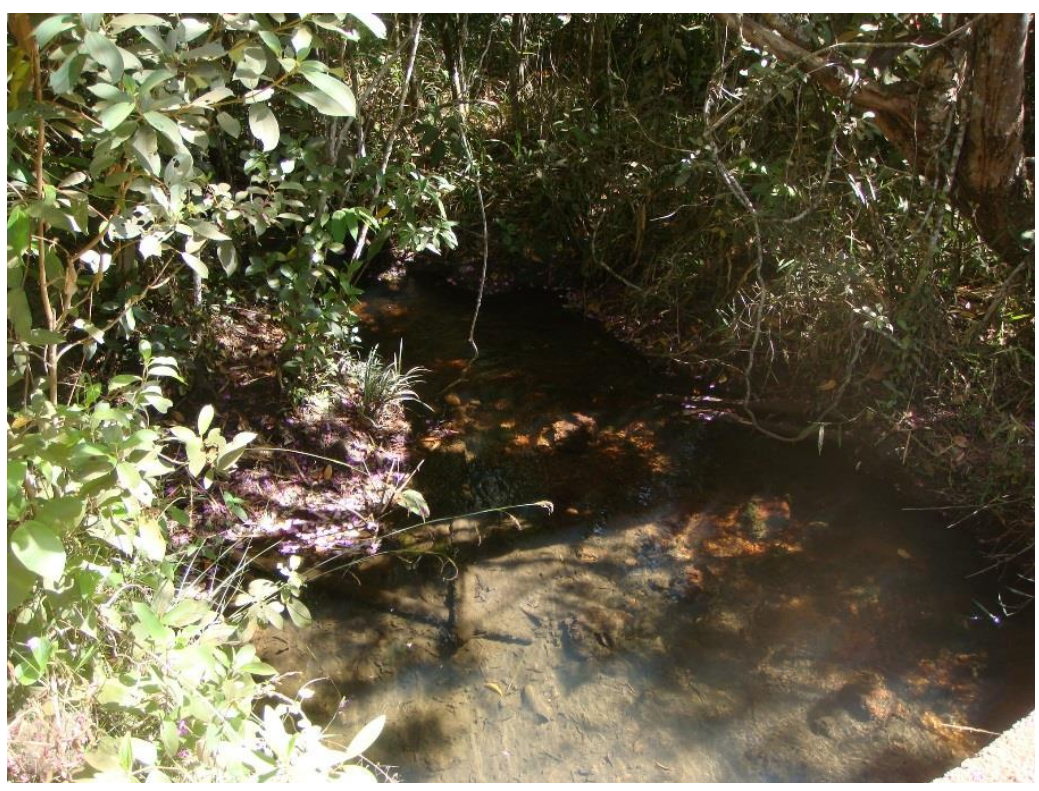

Figura 4. Foto do córrego Roncador na reserva ecológica do IBGE, local onde foram realizadas as coletas de sedimento.

O sedimento utilizado para a extração de DNA total foi coletado em setembro e seus parâmetros físico-químicos foram realizados pela empresa SOLOQUIMICA Análises de Solo Ltda (tabela 5). O valor de $\mathrm{pH}$ ácido é consistente com o encontrado na literatura para solos e sedimentos de lagoa do Cerrado (Zardo et al., 2011; Catão et al.,2013; Rodrigues et al., 2014; Dias, 2015), provavelmente devido à liberação de íons de hidrogênio oriundos das atividades metabólicas dos microrganismos (Esteves, 2011). 
Tabela 5. Análise físico-química do sedimento coletado no dia 02 de Setembro de 2013.

\begin{tabular}{|c|c|}
\hline Parâmetros Analisados & Valores \\
\hline \multicolumn{2}{|l|}{ COMPOSIÇÃO GRANULOMÉTRICA } \\
\hline Argila, $g / \mathrm{kg}$ & 250 \\
\hline Areia, $g / k g$ & 625 \\
\hline Silte, $\mathrm{g} / \mathrm{kg}$ & 125 \\
\hline \multicolumn{2}{|l|}{ COMPLEXO SORTIVO } \\
\hline pH em H2O & 5,6 \\
\hline Fósforo $(\mathrm{P}), \mathrm{ppm}$ & 2,9 \\
\hline Cálcio (Ca), cmolc/dm³ & 0,8 \\
\hline Magnásio $(\mathrm{Mg}), \mathrm{cmolc} / \mathrm{dm}^{3}$ & 0,2 \\
\hline Potássio (k), cmolc/dm³ & 0,06 \\
\hline Sódio (Na), cmolc/dm³ & 0,03 \\
\hline Alumínio (Al), cmolc/dm³ & 1,2 \\
\hline Acidez $(\mathrm{H}+\mathrm{Al}), \mathrm{cmolc} / \mathrm{dm}^{3}$ & 5 \\
\hline Carbono orgânico, g/kg & 26,3 \\
\hline Nitrogênio total , $\mathrm{g} / \mathrm{Kg}$ & 0,79 \\
\hline Nitrato $\left(\mathrm{NO}_{3}\right)$ & 0,25 \\
\hline Nitrito $\left(\mathrm{NO}_{2}\right)$ & 0,15 \\
\hline Nitrogênio amoniacal $\left(\mathrm{NH}_{3}\right)$ & 0,05 \\
\hline Matéria orgânica, g/kg & 45,2 \\
\hline \multicolumn{2}{|l|}{ MICRONUTRIENTES } \\
\hline Boro (B), ppm & 0,51 \\
\hline Cobre $(\mathrm{Cu}), \mathrm{ppm}$ & 0,52 \\
\hline Ferro $(\mathrm{Fe}), \mathrm{ppm}$ & 487 \\
\hline Manganês (Mn), ppm & 1,9 \\
\hline Zinco (Zn), ppm & 3,34 \\
\hline Enxofre $(\mathrm{S}), \mathrm{ppm}$ & 4,2 \\
\hline
\end{tabular}

Para o estabelecimento do cultivo, foi utilizado inicialmente o sedimento coletado em setembro, porém não foi observado crescimento nas placas e, por esta razão, uma nova coleta foi realizada em janeiro a fim de se obter um novo inóculo inicial. O sedimento de janeiro não foi analisado em relação aos seus parâmetros físicoquímicos por questões metodológicas.

Apesar de terem sido coletados em momentos e estações diferentes, o índice pluviométrico dos dois períodos foi similar. Os dados pluviométricos da reserva ecológica do IBGE estão disponíveis na página www.recor.org.br e podem ser observados na figura 5. A precipitação média dos meses de setembro de 2013 e janeiro de 2014 foram 1,7mm e 1,3mm respectivamente (dados obtidos na página da reserva), 
não havendo chuvas nos dias próximos as datas das coletas. Assim, podemos considerar que as duas coletas foram feitas em períodos com precipitações parecidas.

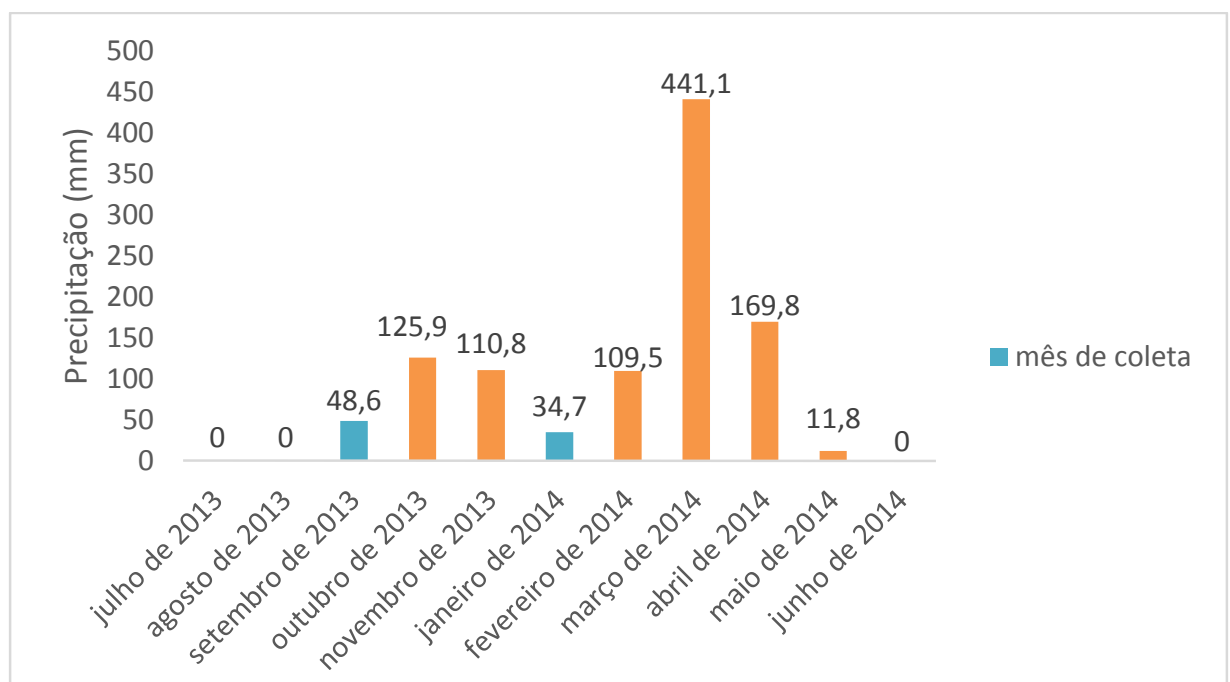

Figura 5. Precipitação total na reserva ecológica do IBGE, no período de julho de 2013 a junho de 2014 (em http://www.recor.org.br/cid360/download/17-dadosmeteorológicos.html acesado em dezembro de 2015). Os dados de precipitação do mês de dezembro de 2013 não foram disponibilizados.

\subsection{Cultivo de archaeas em meios artificiais.}

Para o estabelecimento das culturas laboratoriais de archaeas de sedimentos do cerrado, foi utilizado como meio de cultura o próprio sedimento do qual foi retirado o inóculo inicial. Esta estratégia foi utilizada devido à falta de conhecimento sobre as necessidades nutricionais destes microrganismos e, desta forma, a variedade de nutrientes e suas concentrações provavelmente estariam mais próximas àquelas presentes no meio natural onde estes se encontravam. Os meios de cultura consistiram em um coado do sedimento coletado misturado com a água do córrego e, para a obtenção de meios sólidos, adicionados de ágar. O uso de meios artificiais que mimetizam as características do ambiente tem sido discutido na comunidade científica nos últimos anos e já foi observado com sucesso para o cultivo de bactérias e archaeas (Keberlein et al., 2002; Konneke et al.,2005).

O inóculo inicial do cultivo foi preparado primeiramente no dia 02 de setembro de 2013. Devido a experiências anteriores do nosso grupo de pesquisa com contaminações em culturas de archaeas de solo, foi adicionada à cultura uma 
combinação de antibacterianos e antifúngicos desde o primeiro momento do cultivo, na tentativa de obter culturas puras de archaeas. Foram adicionados os antimicrobianos: ampicilina, estreptomicina, bacitracina, norfloxacina, doxiciclina, clorafenicol, itraconazol, anfotericina B e cetoconazol. Porém, após semanas de cultivo, não foi observado crescimento nas placas, o que pode ter sido causado pelo uso de vários antibióticos desde o primeiro momento. Apesar das diferenças morfológicas e fisiológicas observadas entre archaeas e bactérias e da conhecida resistência das archaeas a antibióticos comumente usados, alguns autores vem demonstrando que membros do domínio Archaea podem apresentar suscetibilidade a alguns destes agentes (Dirdi, 2012; Khelaifia \& Drancourt, 2012). Outra possível explicação para este resultado poderia ser a eliminação de bactérias essenciais à sobrevivência das archaeas nos meios de cultura utilizados. Atualmente, estima-se que cerca de $80 \%$ de todos os procariotos existam na natureza como organismos sésseis, aderidos a superfícies, onde estabelecem associações intra- e interespecíficas (Schopf et al., 2008). Em alguns estudos de cultivo de Archaea, ao se eliminar a bactéria associada a ela, esta também não sobrevivia, sugerindo haver uma dependência metabólica entre estes organismos (Lehtorvita-Morley et al., 2014).

Uma segunda tentativa de cultivo foi feita em janeiro de 2014, a partir da coleta de novos sedimentos e da confecção de um novo inóculo inicial. Para minimizar a contaminação por bactérias e fungos, foram adicionados os agentes antimicrobianos: ampicilina, estreptomicina, clorafenicol e itraconazol. Foram inoculadas quatro placas com quantidades diferentes do inóculo e incubadas em estufa a $28^{\circ} \mathrm{C}$. Após uma semana de cultivo foi possível visualizar mais de um tipo de colônias diminutas, sugestivas de crescimento procariótico em cada placa. As colônias diferentes foram então inoculadas separadamente em novas placas. Em seguida, os repiques foram feitos com intervalos de 2 a 4 semanas entre si, com o objetivo de separar tipos diferentes de crescimento. Posteriormente, foi realizada a adição sucessiva de novos agentes antimicrobianos: anfotericina $\mathrm{B}$, doxiciclina e bacitracina. $\mathrm{O}$ primeiro resultou na morte das culturas e os dois últimos não provocaram qualquer alteração morfológica nas colônias e por esta razão, optou-se pela manutenção dos quatro antimicrobianos originais. Inicialmente foram observados três tipos coloniais distintos que, ao longo do cultivo, foram repicados separadamente na tentativa de isolar as diferentes colônias, resultando em nove culturas homogêneas. 
Para o cultivo das archaeas em meio líquido foi realizado um primeiro inóculo a partir do mesmo sedimento utilizado para o cultivo em meio sólido, em janeiro de 2014. As culturas foram realizadas em tubos contendo o meio líquido suplementado com ampicilina, estreptomicina, clorafenicol e itraconazol e incubadas em estufa a $28^{\circ} \mathrm{C}, \mathrm{sem}$ agitação. O meio líquido foi confeccionado a partir do mesmo coado utilizado para a confecção do meio sólido. Porém, o método de esterilização dos meios foi diferente. Enquanto os meios sólidos foram autoclavados, os meios líquidos foram filtrados em membranas com poros de $0,22 \mu \mathrm{m}$ de diâmetro. Entretanto, não foi observado crescimento nos tubos inoculados, mesmo após meses de incubação. Tal fato foi considerado curioso, tendo em vista que os trabalhos de cultivo de archaeas mesófilas relatam o crescimento destas em meio líquido (Simon et al., 2005; Kim et al., 2012; Xu et al., 2012; Santoro et al., 2014 Stieglmeier et al., 2014; Zhalnina et al., 2014). A dificuldade de crescimento em meio líquido também foi observada em um experimento de cultivo de archaeas de solo do Cerrado realizado pelo nosso grupo (Dias, 2015). Novas tentativas foram feitas a partir de culturas já adaptadas em meios sólidos, sendo adicionado a alguns tubos cloreto de amônio na concentração final de $0,5 \mathrm{mM}$, a fim de enriquecer o crescimento de archaeas com potencial nitrificante. Foram realizados inóculos a partir da coleta de amostras das colônias, que foram ressuspensas no meio líquido e filtradas em membranas com poros de $0,45 \mu \mathrm{m}$ de diâmetro e, a partir destes inóculos, foi possível observar um discreto crescimento nos tubos após meses de incubação, embora sem distinção entre os tubos contendo ou não $\mathrm{NH}_{4} \mathrm{Cl}$.

Os tubos onde foi observado crescimento, bem como as culturas obtidas em meio sólido, foram selecionados para experimentos de extração de DNA e ensaios de PCR (resultados apresentados e discutidos no item 4.3.2).

\subsubsection{Caracterização morfológica das culturas obtidas.}

O cultivo em meio sólido revelou a presença de três tipos coloniais distintos, após cerca de quatro meses de cultivo, denominados tipos coloniais " $A$ " "B" e "C". O tipo colonial "A" apresentava aspecto brilhante, transparente e mucilaginoso, com bordas regulares. Este tipo colonial caracterizava-se por exibir crescimento rápido, com colônias visualizáveis a partir de uma semana de incubação (Figura 6a e b). O tipo colonial "B" consistia em colônias opacas, de bordas irregulares e centro mais denso, bastante aderidas ao meio de cultura. Estas colônias apresentavam tamanho variável, 
podendo atingir cerca de $1 \mathrm{~cm}$ de diâmetro. Seu crescimento era observado cerca de duas semanas após a inoculação (Figura 6c e d). O tipo colonial "C" consistia em colônias muito pequenas, com menos de $1 \mathrm{~mm}$ de diâmetro, que se projetavam do meio, com aspecto irregular e bordas lisas, formando pequenos "pontos" na placa, visualizáveis após cerca de duas semanas de incubação (Figura 6e e f).
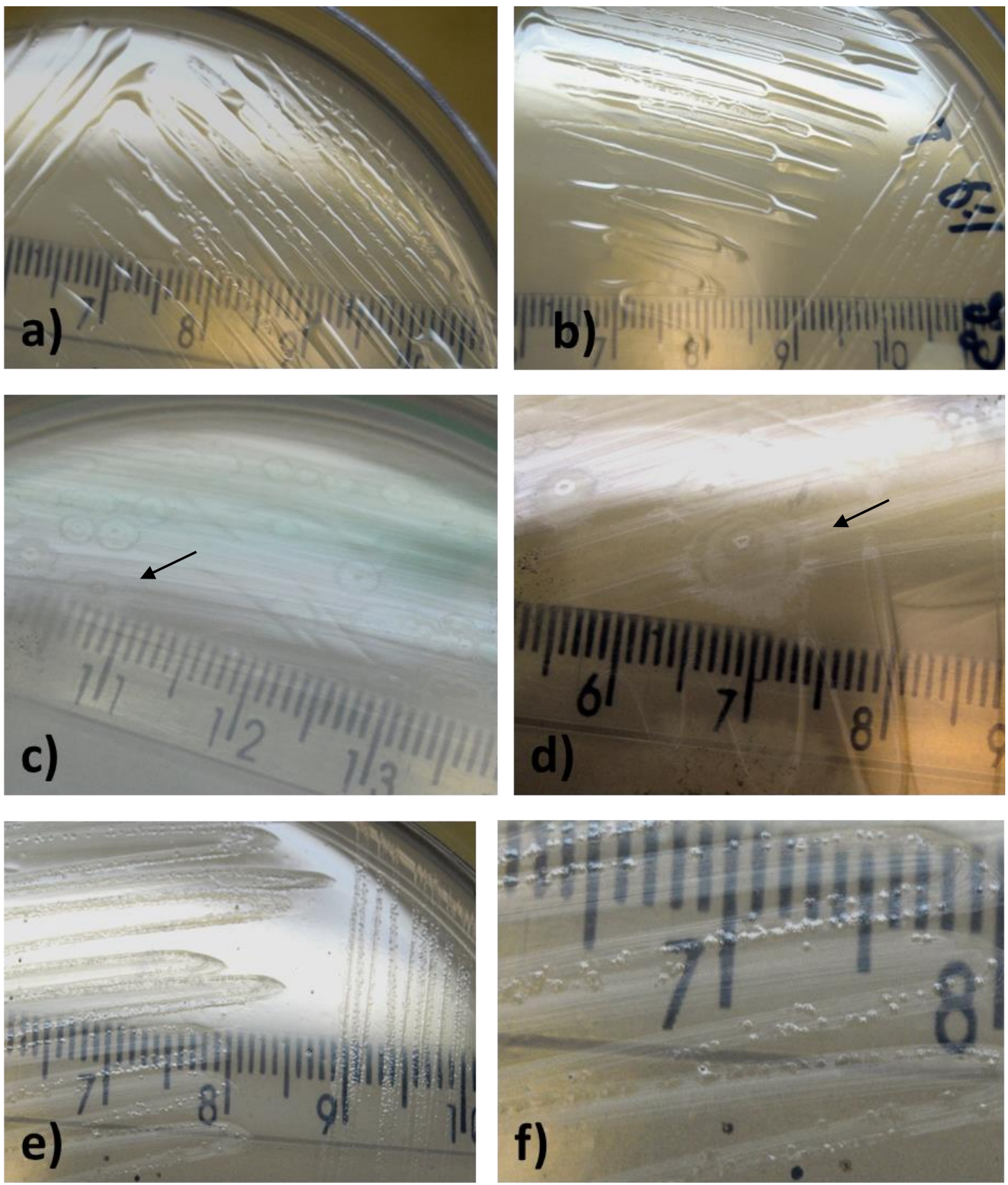

Figura 6.Tipos coloniais obtidos em meios sólidos. $\mathbf{a}$ - b) tipo colonial A; $\mathbf{c}-\mathbf{d}$ ) tipo colonial B; e - f) tipo colonial C. As setas indicam as colônias do tipo colonial "B"

Tendo em vista que experimentos de PCR com iniciadores dirigidos ao gene amoA sugeriam a presença de archaeas com potencial nitrificante nas culturas 
(resultados apresentados e discutidos no item 4.3.2.6.2.), estas passaram a ser inoculadas em meios adicionados de $\mathrm{NH}_{4} \mathrm{Cl}$, na tentativa de favorecer o crescimento de AOAs. Alguns trabalhos descrevem o crescimento de archaeas nitrificantes em culturas de enriquecimento, a partir da suplementação de fontes externas de nitrogênio (Lehtorvita-Morley et al., 2011; Tourna et al., 2011; Kim et al., 2012; Santoro et al., 2014; Stieglmeier et al., 2014). Durante estes repiques foi observada uma mudança morfológica em duas placas em relação às placas controle (sem a adição de $\mathrm{NH}_{4} \mathrm{Cl}$ ).

Em uma das placas (S 05), cujas colônias eram do tipo "A", estas passaram a apresentar aspecto mais translúcido, com dois tipos de crescimento distintos, pequenas colônias de $1 \mathrm{~mm}$ e colônias de morfologia indefinida, com aspecto mais mucilaginoso. As colônias foram então repicadas em placas distintas (denominadas S 5P e 5G) e, após cerca de cinco repiques sucessivos, as duas placas passaram a apresentar colônias com o mesmo aspecto morfológico, de crescimento rápido e bastante aderidas ao meio. Estas colônias foram então consideradas um novo tipo colonial que recebeu a denominação "D" (Figura 7a e b). Outra placa onde foi observada a ocorrência de colônias com nova morfologia inicialmente consistia no tipo colonial "B" (S 07), que passou a formar colônias com bordas mais regulares e tamanho menor, chegando até aproximadamente $3 \mathrm{~mm}$ de diâmetro e centros protuberantes de aspecto brilhante, sendo denominadas como um novo tipo colonial denominado "E". Este tipo colonial era observado mais rapidamente nas placas que o tipo "B” original, após cerca de 10 dias (Figura 7c e d). 

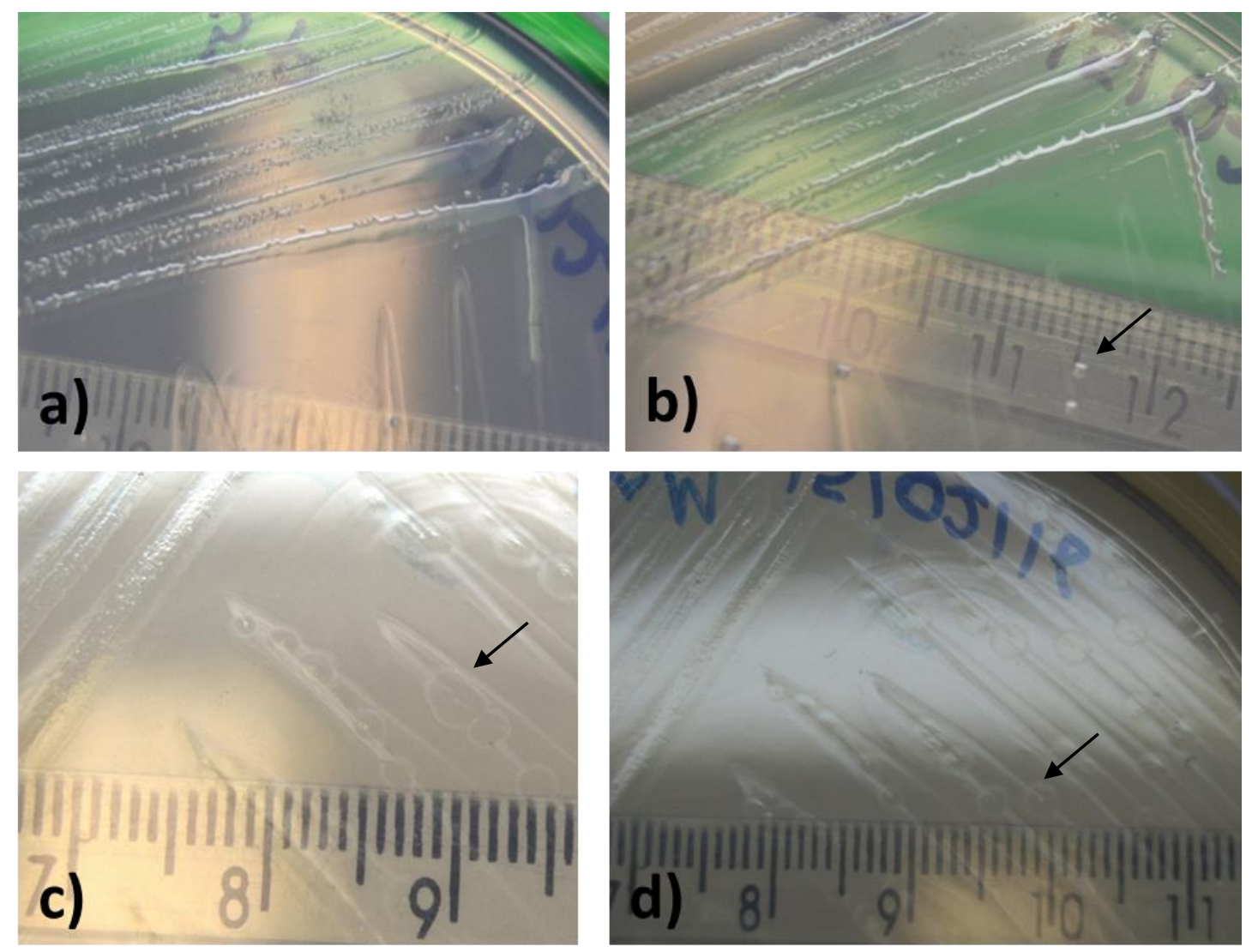

Figura 7. Novos tipos coloniais obtidos após a adição de $\mathrm{NH}_{4} \mathrm{Cl}$ aos meios. a-b) tipo colonial D. c- d) tipo colonial E. As setas indicam as colônias representantes dos tipos coloniais "D" e "E"

Após a obtenção dos resultados que sugeriam a presença de um co-cultivo entre archaeas e bactérias (dados apresentados e discutidos no item 4.3.2.), algumas placas foram selecionadas para passarem por um processo de filtração em membranas com poros de 0,45 $\mu \mathrm{m}$ de diâmetro, na tentativa de reter as bactérias presentes e isolar as archaeas da cultura. Este método foi utilizado com sucesso na obtenção de uma cultura da Thaumarchaeota nitrificante Nitrosotalea devanaterra (Lehtorvita-Morley et al., 2014). As colônias foram retiradas das placas, ressuspendidas em meio líquido, filtradas e inoculadas novamente em meios sólido e líquido. Após o experimento, não foram observadas diferenças morfológicas nas culturas em relação às culturas que não passaram por este tratamento, sugerindo que o método não foi eficiente na eliminação das bactérias da cultura. Porém, as culturas filtradas foram mantidas e tiveram o seu DNA extraído, a fim de verificar uma possível eliminação das bactérias por este processo.

Ao longo do período de cultivo, todas as culturas sofreram discretas alterações morfológicas tais como produção de matriz extracelular, provavelmente devido a 
alterações fisiológicas das células, ou às relações estabelecidas entre os organismos e/ou suas proporções após cada nova semeadura. Entretanto, após cerca de dois anos, as culturas parecem estar estabilizadas em nove culturas distintas, mantendo os cinco tipos morfológicos descritos acima: Três colônias oriundas dos meios adicionados de $\mathrm{NH}_{4} \mathrm{Cl}$, duas com o tipo colonial "D" e uma com o tipo colonial "E"; cinco colônias que passaram pelo processo de filtração em membranas de $0,45 \mu \mathrm{m}$, uma colônia de cada para os tipos coloniais "B", "C" e "D" e duas colônias do tipo colonial "A". A colônia denominada $\mathrm{S} 5 \mathrm{G}$ foi a única colônia oriunda do meio suplementado com $\mathrm{NH}_{4} \mathrm{Cl}$, que passou pelo processo de filtração. (tabela 6).

\begin{tabular}{cccc}
\multicolumn{4}{c}{ Tabela 6. Tipos coloniais e tratamentos realizado } \\
\hline Colônia & $\begin{array}{c}\text { Tipo } \\
\text { colonial }\end{array}$ & NH $_{\mathbf{4}} \mathbf{C l}$ & Filtrada \\
\hline S 01 & A & - & X \\
S 02 & A & - & X \\
S 04 & B & - & - \\
S 5P & D & X & - \\
S 5G & D & X & X \\
S 06 & C & - & X \\
S 07 & E & X & - \\
S 08 & B & - & - \\
S 09 & B & - & X \\
\hline
\end{tabular}

Tendo em vista os resultados preliminares do sequenciamento de DNA dos diferentes tipos coloniais (resultados apresentados e discutidos no item 4.3.2.), seis das nove colônias foram selecionadas para as análises por microscopia óptica e microscopia eletrônica de varredura. As placas escolhidas foram: S 01 e S 02 - tipo colonial "A"; S 5P - tipo colonial "D"; S 06 - tipo colonial “C”; S 07 - tipo colonial "E” e S 09 - tipo colonial "B".

\subsubsection{Coloração de Gram das amostras selecionadas.}

As seis amostras foram preparadas de acordo com o protocolo padrão de coloração de Gram e analisadas ao microscópio óptico, sob aumento de 1000 x. Em todas as preparações foram observadas células diminutas, com contornos de difícil visualização. 
As amostras das colônias coletadas das placas S01 e S02 (ambas do tipo colonial A), consistiam em células Gram negativas pequenas, com morfologia elipsóide. Em alguns campos foram observados aglomerados celulares envoltos por uma camada amorfa, que também se apresentava corada, sugerindo a presença de uma matriz extracelular (Figura 8a e b). A presença de uma matriz extracelular poderia justificar o aspecto mucilaginoso das culturas do tipo colonial "A".

A lâmina confeccionada com colônias provenientes da placa S5P (tipo colonial "D") revelou a presença de dois tipos celulares distintos, células Gram negativas com tamanho e formas similares às das placas S01 e S02 e células de aspecto bacilar, um pouco maiores e de coloração mais intensa (figura $8 \mathrm{c}$ e d). A amostra coletada da placa S06, que possuía o tipo colonial "C", revelou três tipos celulares distintos, dois de coloração Gram negativa e um Gram positivo. Um dos tipos celulares Gram negativos assemelhava-se às células elipsóides observadas nas demais amostras, enquanto o segundo tipo era composto por células menores e de coloração menos intensa. Por outro lado, as células de coloração Gram positiva apresentavam morfologia arredondada (figura 8e e f). 

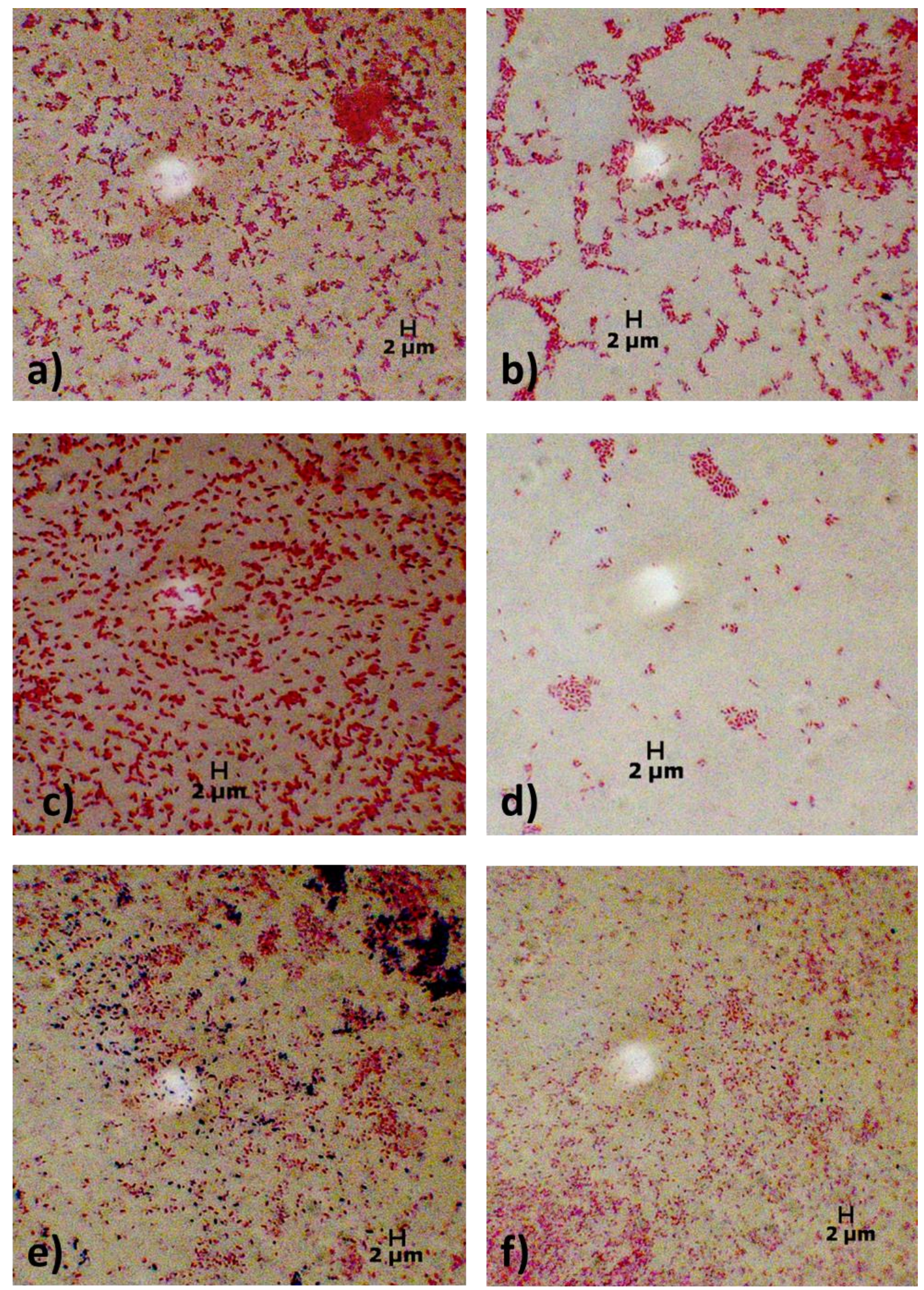

Figura 8. Preparações das colônias selecionadas, coradas pelo método de Gram. a) Placa S 01; b) Placa S 02; c-d) Placa S 5P; e-f) Placa S 06. Aumento de 1000x. 
Nas amostras provenientes das placas S 07 e S 09 foi observada a predominância de células Gram negativas, com algumas células Gram positivas observadas em alguns campos (Figuras 9c e 10). Também foram observados dois padrões de arranjo celular distintos, células isoladas (Figuras 9a e 10a) e células agrupadas em mosaicos (Figuras $9 \mathrm{~b}$ e 10b). A amostra da placa S 07 apresentava células com tamanhos distintos (figura 9), enquanto na amostra da placa 09 foram observadas apenas células elipsóides menores (figura 10).
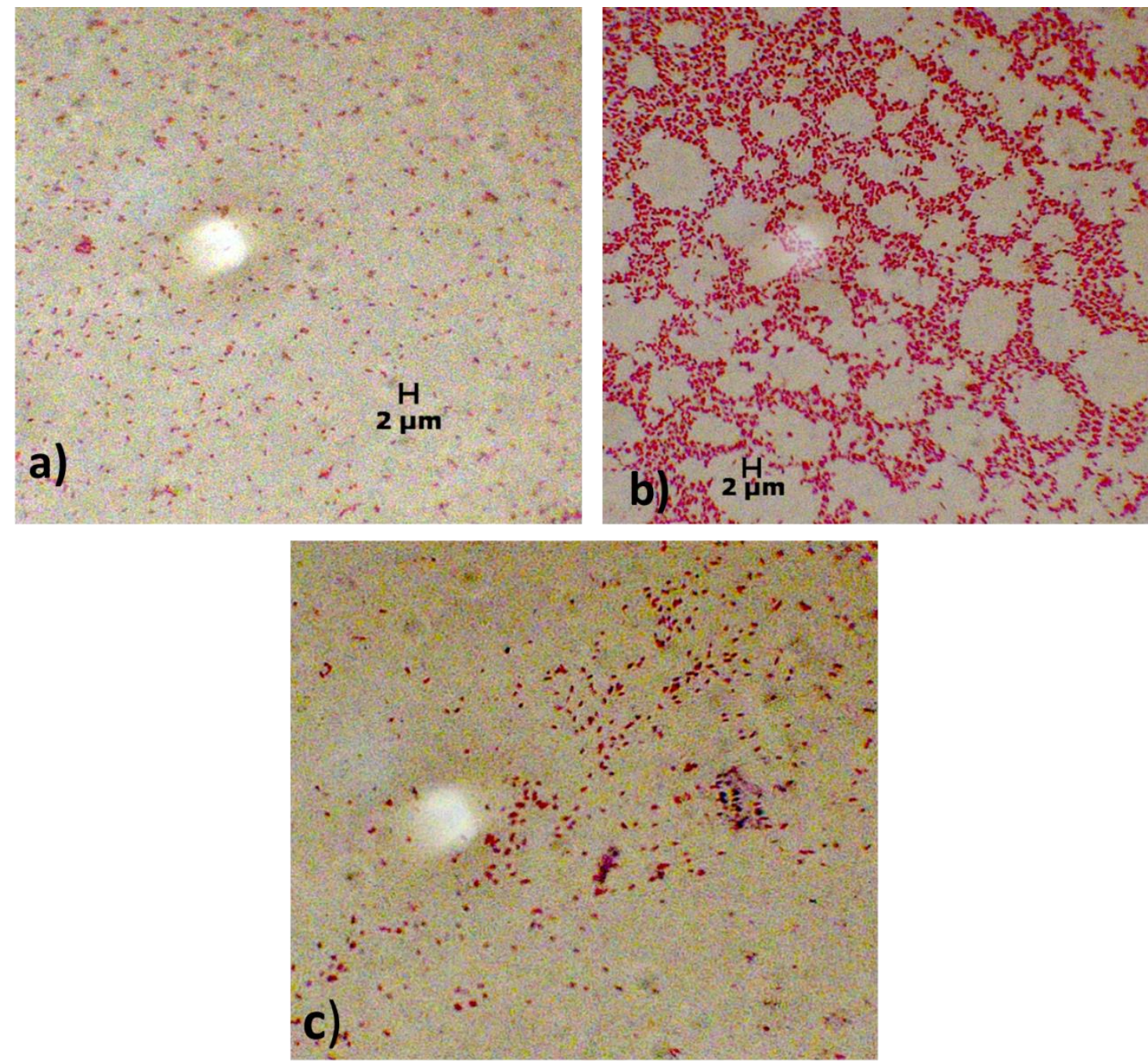

Figura 9. Preparações coradas pelo método de Gram das colônias obtidas na placa S 07. Aumento de 1000x. 

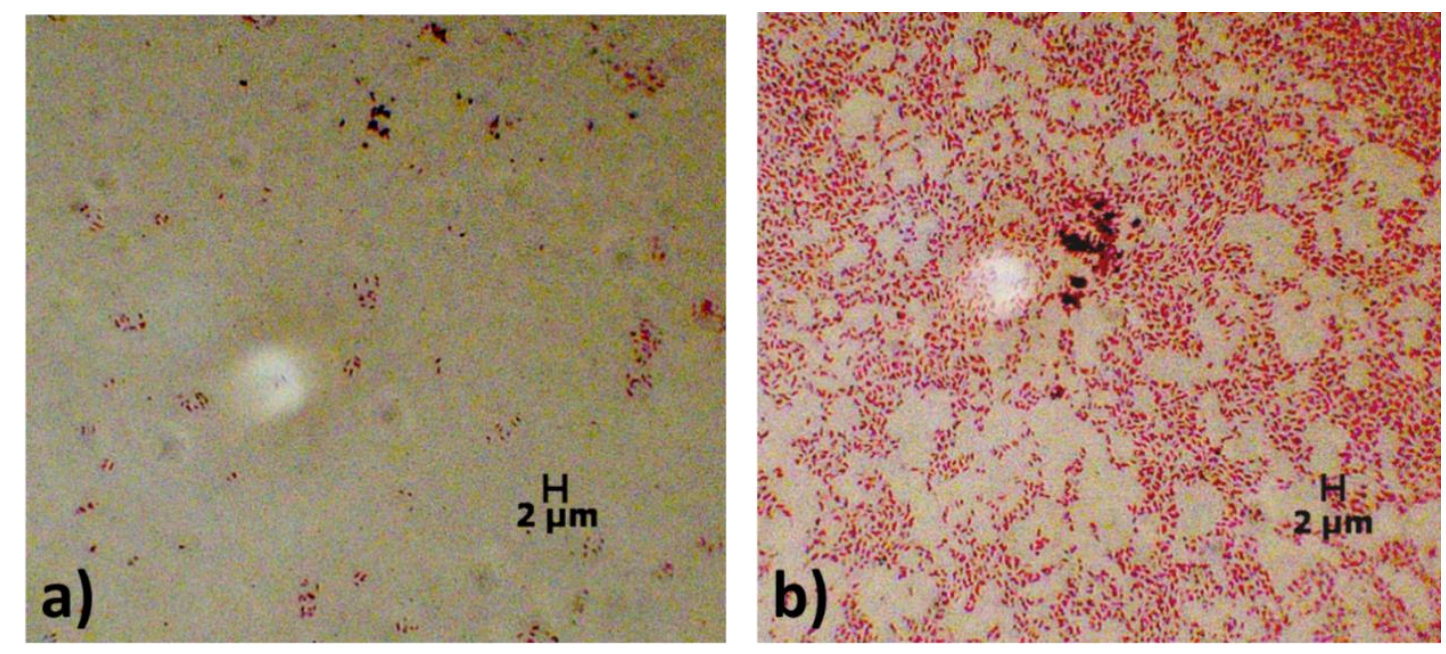

Figura 10. Preparações coradas pelo método de Gram, de colônias selcionadas da placa S 09. Aumento 1000x.

O método de coloração de Gram é amplamente utilizado para a diferenciação morfológica inicial de membros do domínio Bacteria devido às duas estruturas distintas de parede celular destes organismos. Porém, as archaeas possuem uma grande variedade de composição de parede celular que se distinguem das paredes bacterianas (Albers \& Meyer, 2011), por esta razão a relação entre os diferentes tipos de archaeas e a sua coloração por este método ainda não estão definidos.

\subsubsection{Microscopia Eletrônica de Varredura (MEV) das colônias selecionadas.}

Amostras das seis culturas selecionadas foram também analisadas por microscopia eletrônica de varredura, mas por problemas metodológicos, as imagens não permitiram uma caracterização morfológica precisa destas células. Assim, novas preparações serão ainda realizadas visando uma melhor análise da morfologia celular destas amostras.

As amostras coletadas das placas S 01 e S 02 apresentavam células enrugadas, provavelmente com o citoplasma danificado no momento do preparo. A partir da análise do contorno celular pode-se especular que na amostra S 01 as células possuam forma bacilar com tamanho entre 0,8 e $1 \mu \mathrm{m}$, arranjadas como pequenos aglomerados, com padrão semelhante ao observado na microscopia óptica (figura 11a). O material coletado da placa $\mathrm{S} 02$ possuía células semelhantes àquelas da placa $\mathrm{S} 01$, com algumas células de morfologia cocóide (seta na figura 11b). 

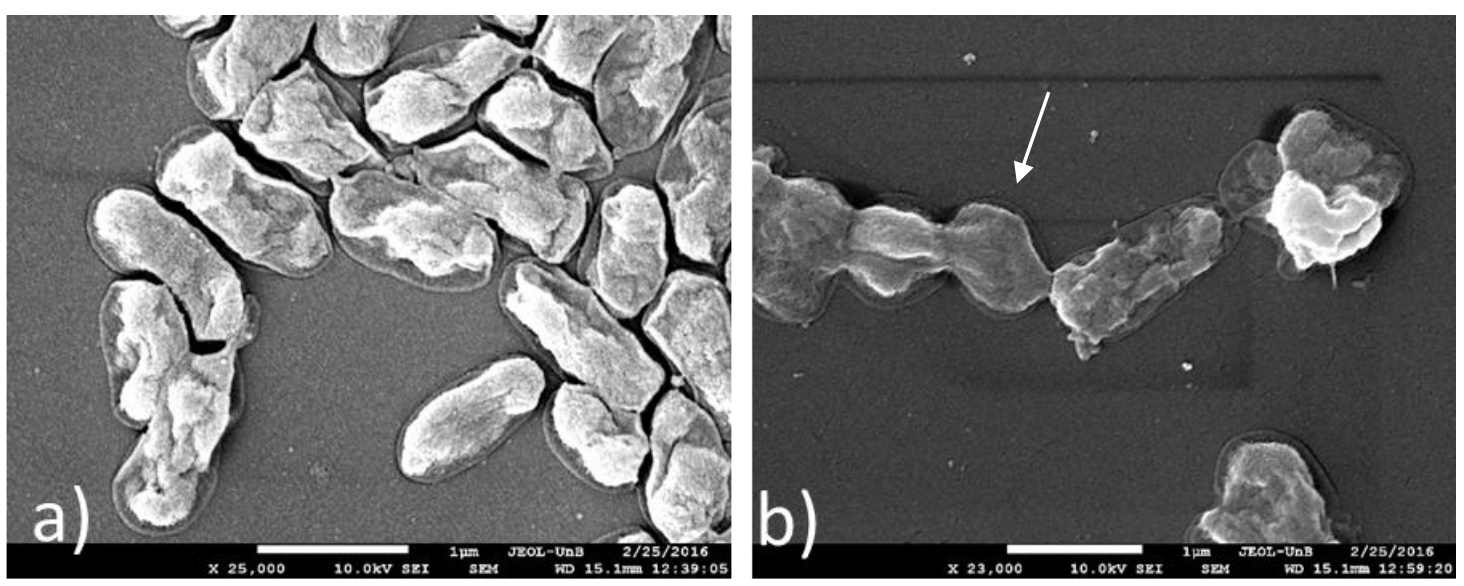

Figura 11. Microscopia eletrônica de Varredura de células coletadas das amostras S 01 (a) e S 02 (b). Os aumentos estão indicados abaixo de cada imagem. Seta - morfologia cocóide na amostra S 02.

As células retiradas da amostra S 5P, apresentavam, em sua grande maioria, morfologia bacilar, com tamanhos que variavam de 0,8 a 1,5 $\mu \mathrm{m}$ (figura 12a). Esta variação do tamanho celular sugere que estas consistam em mais de um tipo de organismo. Em alguns campos foram observadas prováveis projeções citoplasmáticas ligando uma célula à outra (figura 12b). A amostra S 06 apresentou a maioria de suas células danificadas, porém foi possível observar diferentes tipos celulares entre as células mais preservadas (figura 12c e d): um bacilo com pouco menos de $2 \mu \mathrm{m}$ (seta na figura 12d); uma célula bacilar com aproximadamente $1 \mu \mathrm{m}$ (seta na figura $12 \mathrm{c}$ ) e células esféricas de formato irregular (asterisco na figura 12c). 

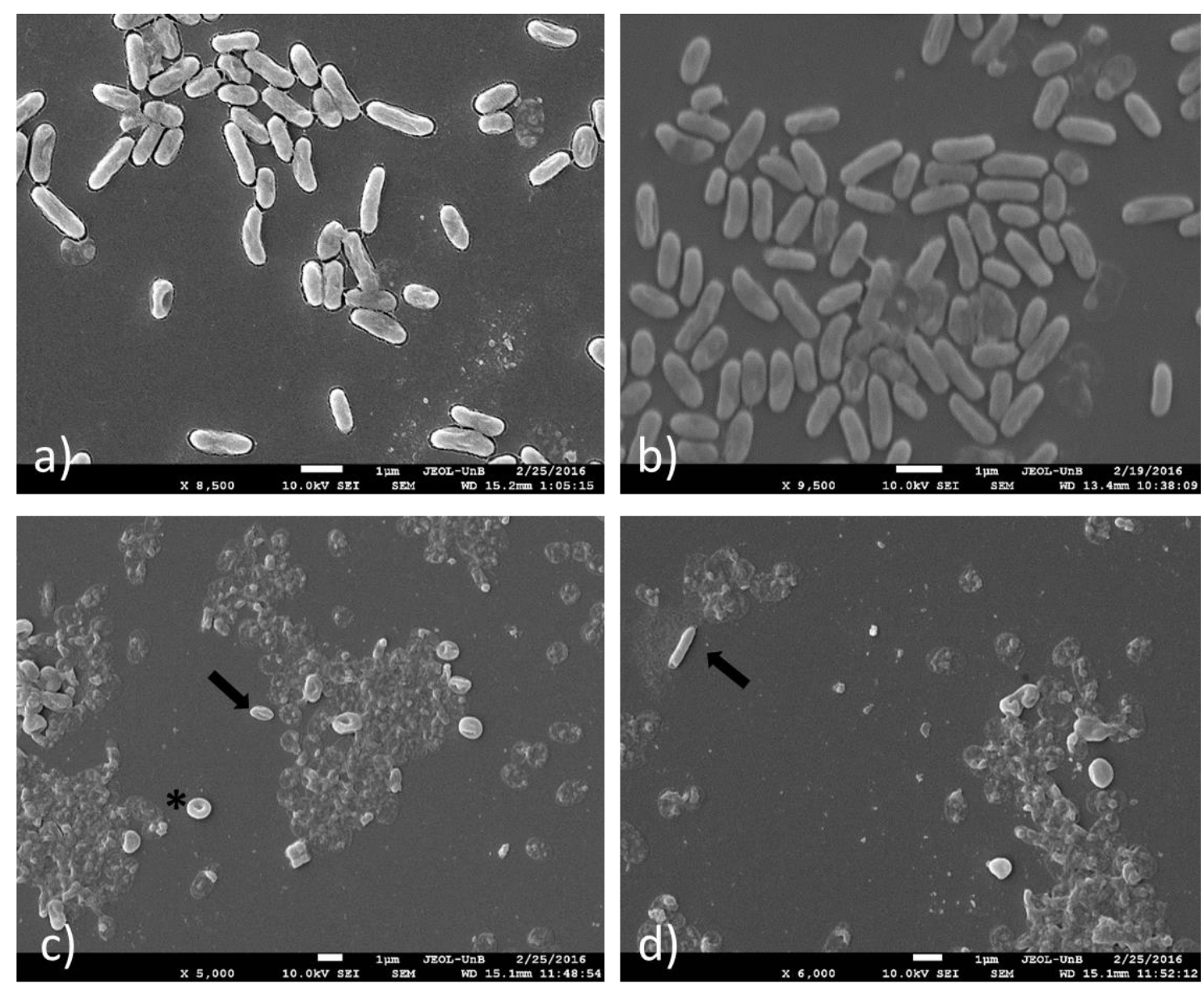

Figura 12. Microscopia eletrônica de Varredura das amostras S 5P (a e b) e S 06 (c e d). Os aumentos estão indicados abaixo de cada imagem. Setas - Tipos morfológicos bacilares. Asterisco - tipo morfológico esférico.

As colônias da amostra S 07 foram analisadas em dois momentos distintos, sendo observadas na primeira análise (em 2014) células bacilares com tamanhos que variavam aproximadamente entre 0,8 e $1 \mu \mathrm{m}$ (figura 13a e b). Estas possuíam superfície regular, com projeções celulares que ligavam uma célula à outra e também as células ao substrato (figura 13a). A segunda análise (em 2016) foi prejudicada devido a problemas no preparo da amostra (figura 13c). Porém, foi possível observar bacilos com uma aparência mais robusta, com cerca de $2 \mu \mathrm{m}$ e uma provável projeção citoplasmática (seta preta), bacilos mais delgados e menores, entre 1,2 e $1,5 \mu \mathrm{m}$ (setas brancas) e células diminutas elipsóides, de até $1 \mu \mathrm{m}$ (asteriscos). 

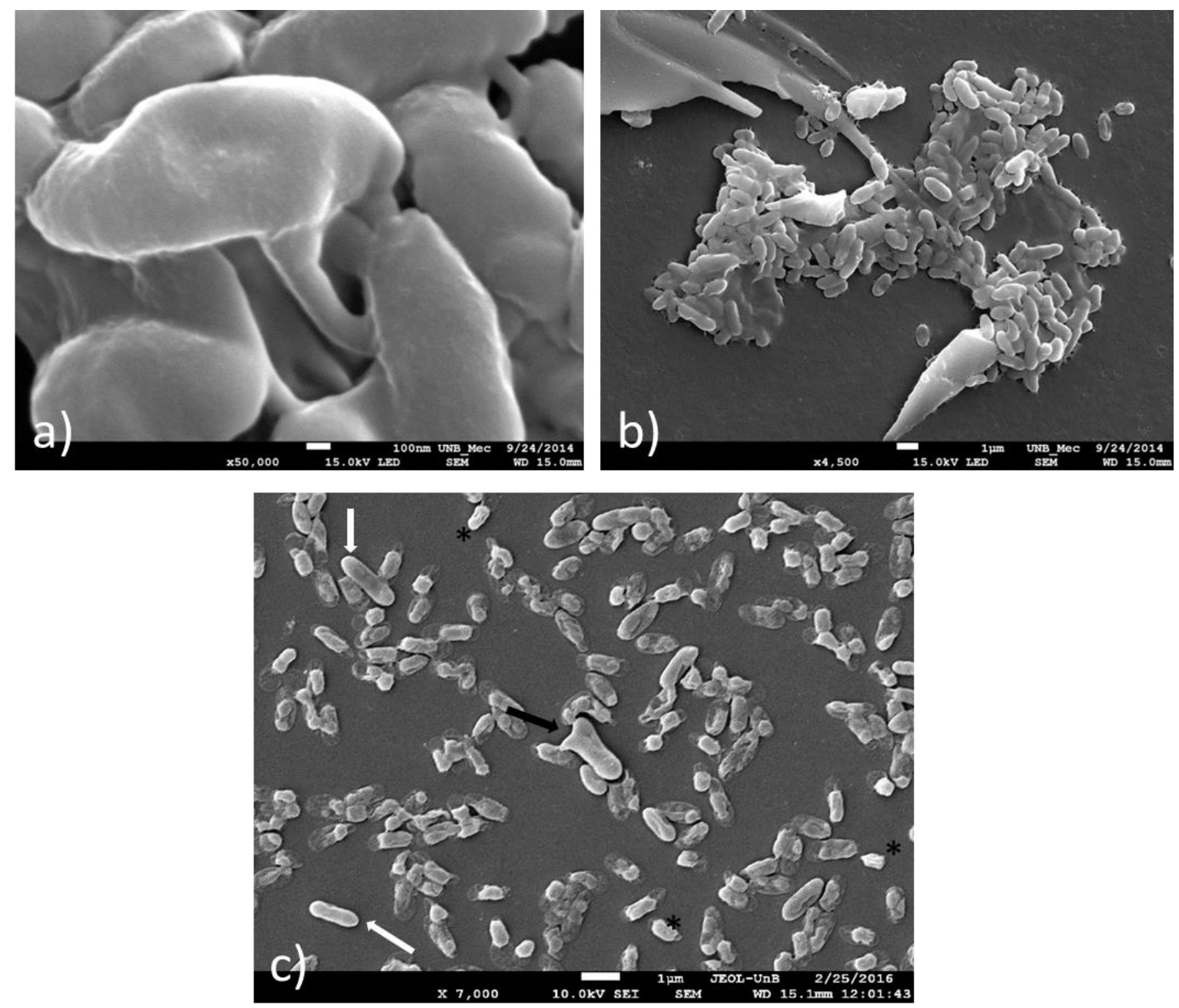

Figura 13. Microscopia eletrônica de Varredura de células coletadas da amostra S 07. Os aumentos estão indicados abaixo de cada imagem. Seta preta $=$ Bacilo maior com possível projeção citoplasmática. Setas brancas $=$ bacilos menores. Asteriscos $=$ possíveis células elipsóides, de menor tamanho.

Na preparação obtida a partir da amostra S 09 foi possível observar três tipos celulares distintos: um bacilo de aproximadamente $3 \mu \mathrm{m}$ (figura 14a); células esféricas irregulares, com cerca de $0,8 \mu \mathrm{m}$ (figura 14b) e bacilos de aproximadamente $1,5 \mu \mathrm{m}$ de comprimento (figura 14c). Células com formatos diferentes foram observadas (asteriscos) porém, devido a problemas no preparo, não foi possível inferir se estas realmente representavam tipos celulares diferentes. 

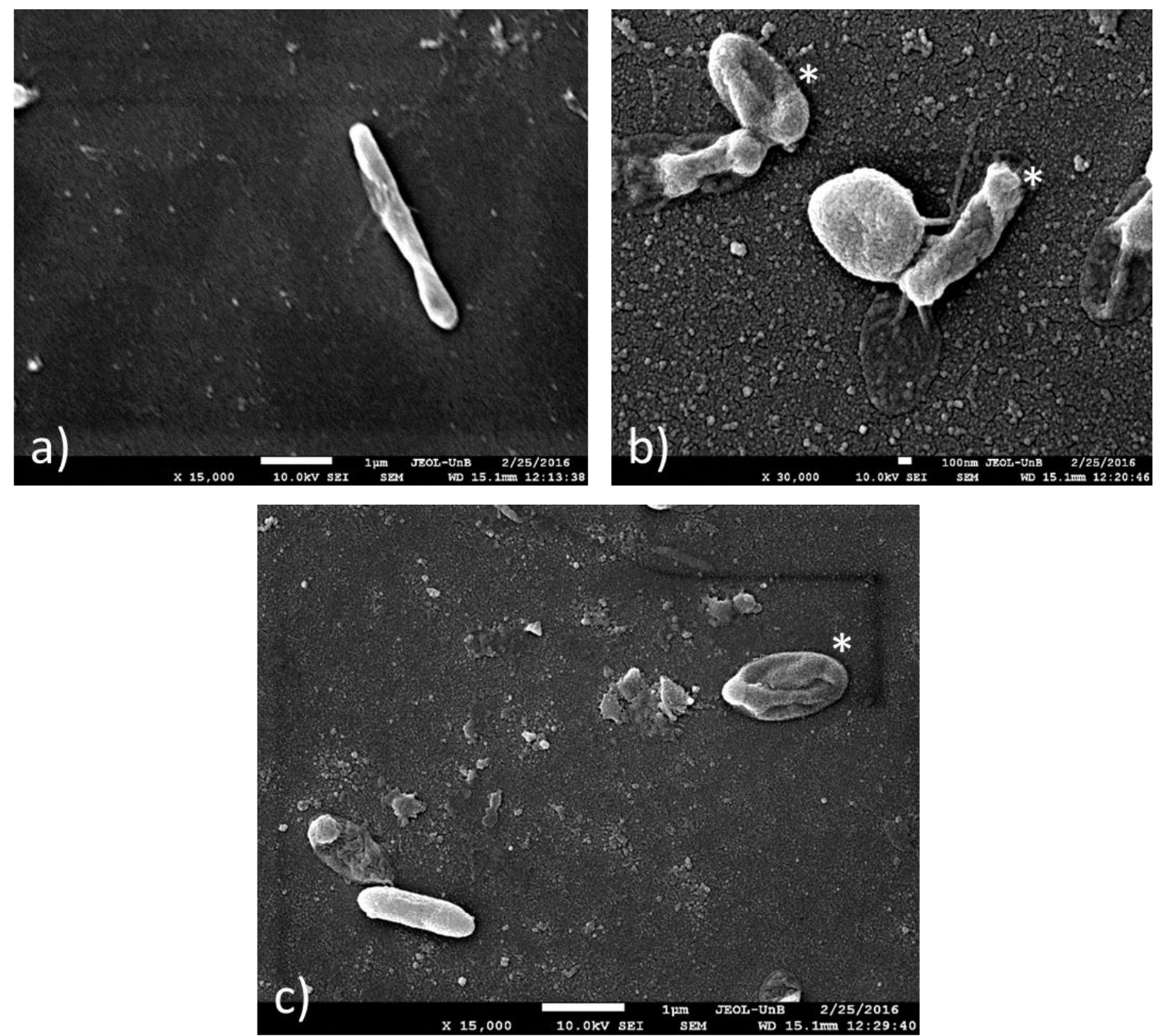

Figura 14. Microscopia eletrônica de Varredura da amostra S 09. Os aumentos usados estão indicados abaixo de cada imagem. Asteriscos = possíveis tipos celulares não identificados.

Resultados do sequenciamento de DNA indicavam que as culturas obtidas consistiam em co-culturas de diferentes tipos de archaeas e uma bactéria para cada amostra (resultado apresentado e discutido no item 4.2.3.6.), sendo todas as bactérias indentificadas como bacilos de 1 a $1,5 \mu \mathrm{m}$ de comprimento, um dos tipos morfológicos também observado em todas as micrografias eletrônicas. Problemas no preparo das amostras para a microscopia eletrônica de varredura dificultaram a análise dos tipos celulares do cultivo, sendo necessário um novo preparo para se obter uma melhor caracterização morfológica de cada amostra. É provavel que as células mais esféricas encontradas sejam representantes de algumas das archaeas da cultura enquanto as células bacilares possam ser representantes tanto de archaeas como de bactérias presentes no cultivo. Porem, não foi possível fazer qualquer relação mais específica entre os tipos morfológicos encontrados e as archaeas identificadas na cultura 


\subsection{Análises de filogenia molecular.}

Com o intuito de comparar as archaeas cultivadas a partir do córrego Roncador com a comunidade de Archaea que se encontra presente no sedimento deste córrego, foram realizadas análises de filogenia molecular utilizando DNA extraído diretamente das amostras de sedimento do córrego, sendo seus resultados utilizados em análises comparativas com os resultados obtidos a partir das análises de filogenia molecular utilizando o DNA extraído das culturas obtidas em meios artificiais.

Por esta razão, este item será dividido em dois tópicos: 4.3.1. - Que abordará os resultados obtidos a partir do sedimento do córrego Roncador e 4.3.2. - Que apresentará os resultados de filogenia molecular das archaeas cultivadas em meios artificiais.

\subsubsection{Filogenia molecular do sedimento do córrego Roncador.}

\subsubsection{Extração do DNA genômico total}

O DNA total do sedimento coletado foi extraído por meio do Kit PowerSoil (MO Bio), que baseia-se em uma extração direta por meio da lise das células presentes na matriz do solo. De acordo com o procedimento, o DNA é separado desta matriz e dos restos celulares em uma etapa posterior (Ogram et al., 1987). A qualidade da extração foi considerada satisfatória, uma vez que o padrão eletroforético em gel de agarose 1\% corado com brometo de etídio revelou a presença de DNA de alta massa molecular, com pequeno indicativo de degradação e concentração de aproximadamente $9 \mathrm{ng} / \mu \mathrm{L}$ (Figura 15).

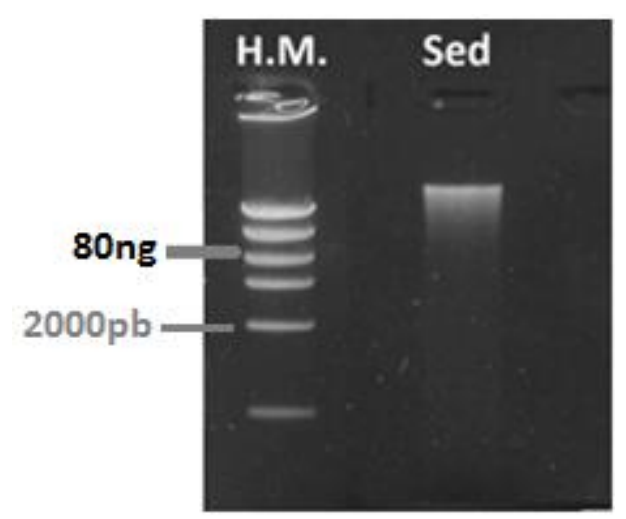

Figura 15. Perfil eletroforético em gel de agarose $1 \%$ corado com brometo de etídio da extração do DNA total do sedimento coletado. $\mathrm{HM}=$ marcador de massa molecular High Mass Ladder (Invitrogen). 


\subsubsection{Amplificação de fragmentos de DNA dos genes do rRNA 16 e da enzima amônia monoxigenase A (amoA) de Archaea.}

Em 1992, DeLong propôs a utilização do par de iniciadores 21F/948R para amplificar uma região do gene de rRNA 16S de Archaea, visando a detecção de membros deste domínio de origem planctônica, em ambientes não extremos. Desde então, este par tem sido utilizado em vários trabalhos que descrevem a presença de archaeas em diversos ambientes, sendo empregado anteriormente com sucesso pelo nosso grupo de pesquisa na caracterização de membros de Archaea em solos (Catão et al., 2013; Dias, 2015) e sedimentos de lagoa (Rodrigues et al., 2014) do Cerrado. Por este motivo, este par também foi selecionado para a amplificação de genes de rRNA 16S de Archaea neste trabalho. Para a detecção de genes do rRNA 16S originários de membros do domínio Bacteria foi utilizado o par de iniciadores 27F/1492R (Lane, 1991).

Para verificar a existência de archaeas com a capacidade de oxidar amônia, foi escolhido o par de iniciadores ArchamoAF/ArchamoAR (Francis et al., 2005), que tem sido usado para a detecção de AOAs em diversos ecossistemas (Auguet et al., 2012; Pester et al., 2012; Vissers et al.,2013), incluindo sedimentos de lagoa de Cerrado (Rodrigues et al., 2014). Este par amplifica um fragmento de 635 pb do gene que codifica a subunidade A da enzima amônia monoxigenase de Archaea e corresponde ao gene quase completo.

Foram utilizadas diferentes concentrações do DNA, resultando na amplificação de fragmentos no tamanho esperado para todas as concentrações utilizadas. A fim de se obter uma maior concentração final dos produtos amplificados, os fragmentos de cada gene específico foram reunidos em uma única amostra e então purificados. O perfil eletroforético dos DNAs purificados revelou fragmentos no tamanho esperado para ambos os pares (937 pb para $16 \mathrm{~S}$ e $635 \mathrm{pb}$ para $a m o A)$. 

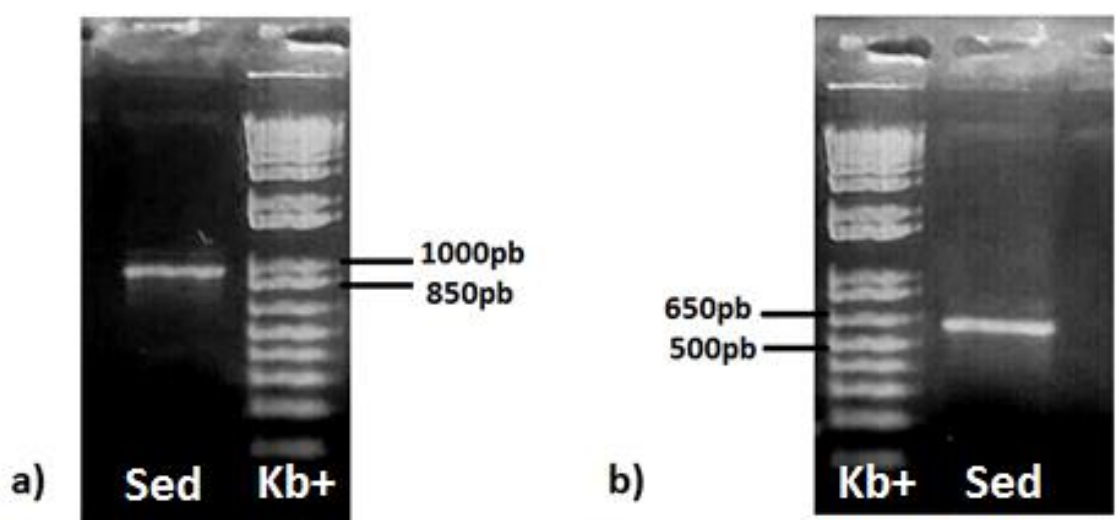

Figura 16. Perfil eletroforético em gel de agarose $1 \%$ corado com brometo de etídio dos produtos de PCR obtidos com os iniciadores relativos ao gene de rRNA 16S de Archaea (a) e $a m o A$ (b). $\mathbf{K b}+=$ Marcador $1 \mathrm{~Kb}$ Plus ladder (Invitrogen).

\subsubsection{Transformação células de Escherichia coli DH5a e seleção de clones recombinantes.}

Os amplicons relativos aos genes de rRNA 16S e amoA de Archaea obtidos nos ensaios de PCR e purificados foram ligados ao vetor pGEM-T Easy® (Promega) e utilizados na transformação por choque térmico de células de E.coli DH5a. Em seguida, o sistema de transformação foi semeado em placas contendo meio LB sólido adicionado de ampicilina, Xgal e IPTG e incubadas em estufa por uma noite. As colônias recombinantes foram selecionadas e estocadas em glicerol 35\%. Foram obtidos 96 clones recombinantes do gene de rRNA $16 \mathrm{~S}$ e 48 clones do gene amoA.

\subsubsection{Extração de DNA plasmidial.}

Os clones recombinantes tiveram seu DNA extraído por lise alcalina, o qual foi enviado para o sequenciamento automático de DNA. A concentração e pureza do DNA foram avaliadas por meio de gel de agarose $1 \%$ corado com brometo de etídio (Figura 17). 


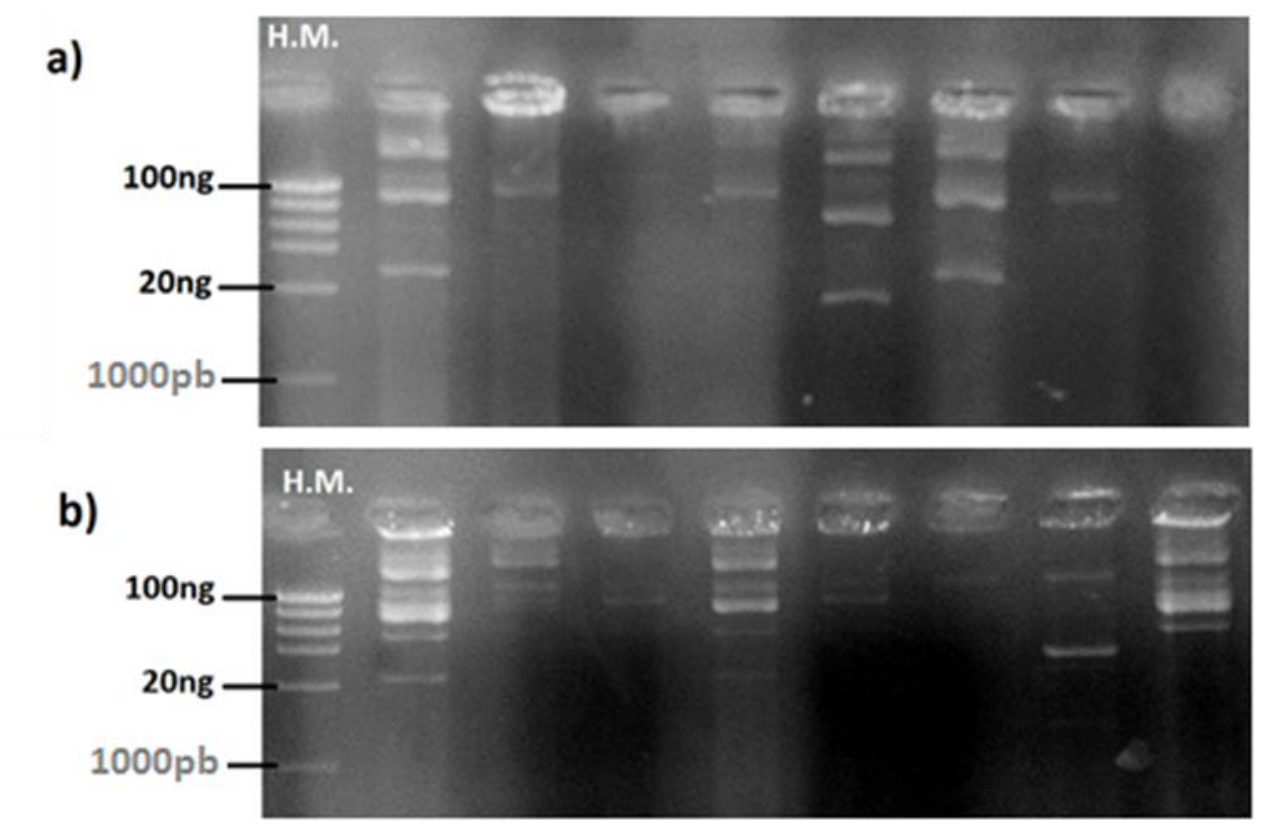

Figura 17. Perfil eletroforético em gel de agarose $1 \%$ corado com brometo de etídio da extração de DNA plasmidial de clones recombinantes contendo segmentos dos genes de (a) rRNA $16 \mathrm{~S}$ e (b) amoA de Archaea. H.M. = Marcador High Mass Ladder (Invitrogen).

\subsubsection{Sequenciamento automático de DNA.}

Os DNAs plasmidiais extraídos dos clones recombinantes foram submetidos ao sequenciamento automático pelo método de Sanger, realizado pelo laboratório de Biologia molecular da Universidade de Brasília e pela empresa Macrogen, na Coréia do Sul. O iniciador $21 \mathrm{~F}$ foi utilizado para o sequenciamento dos clones contendo os fragmentos do gene de rRNA $16 \mathrm{~S}$, enquanto para o gene amoA foi utilizado o iniciador ArchamoAF, sendo obtida uma biblioteca genômica para cada um dos genes estudados. Destas, 36 sequências relativas ao gene rRNA16S e 8 de amoA foram descartadas por possuírem um valor de PHRED (Ewing et al., 1998) menor que 20 para 250 bases. Ao analisar as sequências restantes no programa BioEdit, foram descartadas oito sequências do gene de rRNA $16 \mathrm{~S}$ e duas sequências de $a m o A$, por não apresentarem alinhamento adequado, restando um total de 52 sequências referentes ao gene de rRNA $16 \mathrm{~S}$ e 38 de amoA. 


\subsubsection{Análises filogenéticas do gene de rRNA 16S do domínio Archaea.}

4.3.1.6.1. Classificação taxonômica pelo banco de dados Greengenes.

O banco de dados do Greengenes realiza um alinhamento múltiplo de sequências do gene rRNA 16S de Archaea e Bacteria, levando em conta a taxonomia proposta por diferentes curadores, como NCBI e o Ribossomal Database Project (RDP). A grande adição de sequências de microrganismos nos últimos anos tem gerado algumas incongruências em relação à classificação taxonômica dos organismos (Auguet et al.,2010). Em Archaea, este problema é agravado devido à deposição de sequências de organismos com informações taxonômicas imprecisas, tais como sequências de organismos obtidos apenas por métodos independentes de cultivo, bem como a proposição de novos táxons a medida que estas sequências são adicionadas. Apesar disto, esta ferramenta é considerada muito útil pois visa facilitar a classificação dos organismos ao usar uma combinação de diferentes bancos de dados (DeSantis et al., 2006), sendo escolhida como uma das ferramentas para as análises das sequências de rRNA 16 S deste trabalho.

Das 52 sequências analisadas, 48 apresentaram 100\% de identidade com o domínio Archaea. Das sequências restantes, três apresentaram identidade inferior a 90\% com o domínio Bacteria e uma apresentou identidade inferior a 90\% com o domínio Archaea, com classificação duvidosa. Por esta razão, estas quatro sequências foram descartadas das análises posteriores. A tabela 7 apresenta a classificação taxonômica das 48 sequências restantes, onde obteve-se $100 \%$ de identidade com o banco de dados Greengenes.

Tabela 7. Classificação taxonômica das sequências do gene de rRNA 16S do sedimento, gerada pelo banco de dados Greengenes.

\begin{tabular}{cccc}
\hline $\begin{array}{c}\mathbf{N}^{\mathbf{0}} \mathbf{d e} \\
\text { sequências }\end{array}$ & Filo & Classe & Ordem \\
\hline 18 & Crenarchaota & Thaumarchaeota & Cenarchaeales \\
16 & Crenarchaota & C2 & PGrfC26 \\
6 & Crenarchaota & Sd_NA & NRP-J \\
8 & Euryarchaeota & Methanomicrobia & ---- \\
\hline
\end{tabular}

De acordo com o Greengenes, as sequências obtidas são classificadas nos filos Euryarchaeota, na classe Methanomicrobia, e Crenarchaeota. Porém, vale ressaltar que este banco de dados ainda considera o filo Thaumarchaeota como uma classe pertencente ao filo Crenarchaeota. Como mencionando anteriormente, o filo 
Thaumarchaeota foi proposto em 2008 por Brochier-Armanet e colaboradoes e vem sendo considerado um filo independente por vários autores. Por esta razão, as análises realizadas neste trabalho consideraram Thaumarchaeota como um filo independente de Archaea. Das 18 sequências associadas a este filo, todas pertencem a um grupo de archaeas denominadas SAGMA-X (do inglês South African Gold Mine Archaea), encontradas em minas de ouro da África do Sul (Takai et al., 2001). Este grupo se afilia próximo ao grupo 1.1a de Thaumarchaeota (Könneke et al., 2005), subgrupo pertencente ao antigo grupo I de Crenarchaeota caracterizado por organismos predominantemente de ambientes aquáticos, pertencentes à ordem Cenarchaeales, onde se encontram as archaeas nitrificantes Nitrosopumilus maritimus e Nitrosoarchaeum limnia.

Seis sequências foram classificadas como pertencente à ordem NRP-J do filo Crenarchaeota. Tais organismos também vem sendo considerados como pertencentes ao filo Thaumarchaeota e contém clados afiliados ao grupo I.1c, anteriormente classificado como um dos subgrupos do grupo I de Crenarchaeota (Swanson \& Sliwinski, 2013). O grupo I.1c ainda não possui representantes cultivados, sendo identificado pela primeira vez em solos de floresta finlandeses (Jurgens et al., 2011) e tipicamente associado a organismos de solos ácidos.

As 16 sequências restantes, foram classificadas como pertencentes à ordem pGrfC26 do filo Crenarchaeota. Todavia, tal ordem é frequentemente denominada Miscellaneous Crenarchaeotic Group (MCG) e, como indicado pelo nome, consiste em um grupo de organismos com características bastante distintas, apesar do grau de similaridade em relação à sequência do gene de rRNA 16S. Apesar de MCG consistir em um grupo de sequências de DNA oriundas de amostras ambientais, sem qualquer membro cultivado em meios artificiais, recentemente foi proposto que este grupo fosse considerado um novo filo, denominado Bathyarchaeota (Meng et al., 2014), sendo aparentemente bastante ubíquo (Barns et al., 1996; Huang et al., 2003; Parkes et al., 2005).

É interessante notar que todas as sequências obtidas a partir do sedimento do córrego Roncador, inicialmente classificadas como Crenarchaeota pelo Greengenes, sofreram recentes mudanças em sua classificação taxonômica, sendo classificadas em diferentes filos propostos para Archaea. Tal fato evidencia a necessidade da obtenção de mais informações acerca deste domínio para melhor entendermos as relações evolutivas dos organismos pertencentes a ele. 


\subsection{Análise de alfa-diversidade.}

As 48 sequências de DNA obtidas do sedimento foram analisadas em relação à sua diversidade, com o objetivo de observar uma possível relação entre a diversidade do ambiente e os organismos cultivados em laboratório a partir deste mesmo sedimento. Ao se analisar a diversidade de um ambiente, deve-se levar em conta dois conceitos importantes: a riqueza, que se refere ao número de espécies encontradas em uma comunidade (Peet, 1974) e a abundância, que se refere a homogeneidade de distribuição destas espécies (Melo, 2008). Tendo isso em mente, foram realizadas análises de $\alpha$ diversidade, que diz respeito a riqueza de espécies encontrada em um determinado local (Barros, 2007).

Há uma grande dificuldade na classificação de procariotos ao nível de espécie e, por esta razão, o termo “ Unidade Taxonômica Operacional” (OTU) é amplamente utilizado para esta finalidade. O termo OTU se refere a um conjunto de linhagens que possuem alto grau de similaridade em características independentes (Tuomisto, 2010). Estudos que analisaram a similaridade de sequências do gene de rRNA 16S de diferentes organismos relataram que, para indicar organismos de uma mesma espécie, seria necessária uma similaridade de $97 \%$ entre as sequências (Stackedt \& Goebel, 1994). Os índices de similaridade amplamente utilizados para se identificar os diferentes táxons são: $80 \%$ para filo, 90\% para classe/família, 95\% para gênero e 97\% para espécie (Shloss \& Hendelsman, 2004) e, por esta razão, foram adotados neste trabalho. Estes índices também podem ser denominados índices de dissimilaridade, que representam a porcentagem de diferenças encontradas entre as sequências, sendo então 3\%, 5\%, 10\% e $20 \%$ os índices de dissimilaridade para espécie, gênero, classe/família e filo, respectivamente.

Para as análises de diversidade das sequências, foram utilizados índices nãoparamétricos que avaliam comparativamente a proporção de OTUs encontradas uma única vez (singletons) com aquelas encontradas mais vezes. O índice CHAO (Chao, 1984) estima a riqueza a partir dos números de OTUs (sobs), singletons e doubletons (sequências encontradas duas vezes na amostra) enquanto o ACE (Chao \& Lee, 1992) se baseia no grau de cobertura da amostra, incorporando dados de sequências encontradas menos de dez vezes. A cobertura estima a eficiência da amostragem do ambiente, indicando a porcentagem de indivíduos desta comunidade que foram amostrados para cada táxon específico. 
Nas 48 sequências analisadas, foram encontradas 29 OTUs com 97\% de similaridade sendo 23 destas representadas por singletons. Os índices de riqueza apontaram que a comunidade de archaeas do sedimento pode ser considerada rica, sendo estimado números de OTU maiores do que os encontrados nos dois índices utilizados. A cobertura da comunidade foi de 58,33\% para o nível de espécie, indicando que mais sequências são necessárias para se obter uma maior representatividade da comunidade do sedimento do córrego Roncador.

Tabela 8. Número de OTUs observadas, índices de riqueza (Chao e ACE) e cobertura estimada para a amostra do DNA total do sedimento do córrego roncador em cada um dos índices de similaridade.

\begin{tabular}{cccccc}
\hline Similaridade $(\%)$ & $\mathrm{n}^{\text {o }}$ seqs & OTUs & Chao & ACE & Cobertura \\
\hline 97 & 48 & 29 & 56,142 & 191,383 & $58,33 \%$ \\
95 & 48 & 19 & 110,000 & 138,345 & $70,83 \%$ \\
90 & 48 & 14 & 21,000 & 32,9483 & $85,41 \%$ \\
80 & 48 & 4 & 4,000 & 4,000 & $100,00 \%$ \\
\hline
\end{tabular}

O número de sequências que representam os diferentes filos encontrados (índice de similaridade $80 \%$ ) não corresponde ao número de filos encontrado na análise taxonômica realizada. De acordo com o Greengenes foram observados apenas dois filos; Crenarchaeota e Euryarchaeota. Porém, como mencionado anteriormente, a constante mudança e proposição de novos filos devido a adição de novas sequências nos bancos de dados, gera uma dificuldade na classificação taxonômica da comunidade de Archaea. Além disso, vale lembrar que nossos resultados revelaram a ocorrência de 16 sequências afiliadas ao grupo MCG, atualmente considerado um novo filo, Bathyarchaeota.

Para se estimar a cobertura da amostragem obtida da comunidade do sedimento, foram construídas curvas de rarefação para cada índice de disimilaridade descrito anteriormente, nas quais foram observadas a correlação entre o número de OTUs obtidas e o número total de sequências. Curvas que indicam uma boa cobertura de amostragem se encontram próximas de atingir o platô no gráfico de rarefação (Figura $18)$. 


\section{Sedimento Total}

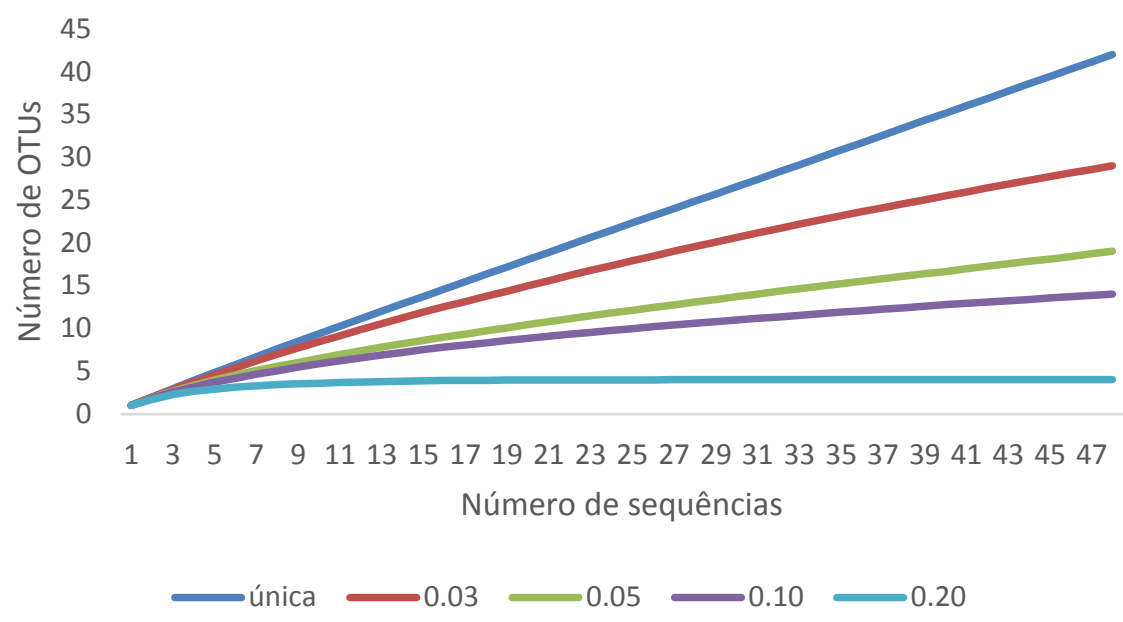

Figura 18. Curvas de rarefação obtidas para a amostra do sedimento do córrego Roncador. Cada curva representa um índice de similaridade: único $=100 \%, 0.03=97 \%$, $0.05=95 \%, 0.10=90 \%$ e $0.20=80 \%$.

A análise das curvas de rarefação indica que o número de sequências foi suficiente para amostrar a comunidade do sedimento apenas para os níveis de filo (0.20) onde foi alcançado $100 \%$ de cobertura, atingindo o platô no gráfico, e para o nível de classe (0.10), que se encontrou próxima de atingir um platô com cobertura de 85,41\%. Para se obter uma boa cobertura para os outros níveis taxonômicos, seria necessário a obtenção de um maior número de sequências por meio de novos experimentos de PCR, clonagem dos produtos obtidos, transformação de $E$. coli e sequenciamento de DNA.

\subsubsection{Análises filogenéticas do gene amoA.}

As 38 sequências de DNA relativas ao gene amoA do sedimento foram alinhadas pelo programa ClustalX e analisadas com o programa Mothur em relação ao número de OTUs observadas e a cobertura estimada da amostragem, com índice de similaridade de 97\% representando a espécie, valor adotado por outros autores para este gene (Zhang et al., 2008; Taylor et al., 2012; Li et al., 2012). Foram reconhecidas 17 OTUs, sendo 10 representadas por singletons e correspondendo a uma cobertura de 73,68\%. O valor da cobertura indica que seriam necessárias mais sequências para obter-se uma amostragem total da comunidade de archaeas com potencial nitrificante presentes nos sedimentos do córrego Roncador. 
Visto que as análises da comunidade de Archaea de sedimento foram realizadas com fins comparativos, as sequências obtidas para os genes de rRNA16S e amoA foram utilizadas para a construção de árvores filogenéticas que também continham as sequências de DNA obtidas a partir das culturas em meios sólidos, visando comparar a comunidade de archaeas de sedimento no córrego Roncador com as culturas obtidas em laboratório a partir deste córrego. As árvores serão apresentadas e discutidas no item 4.3.2.7.

\subsubsection{Filogenia molecular das culturas obtidas.}

\subsubsection{Extração de DNA genômico total.}

A extração de DNA genômico total das culturas em meio sólido foi realizada pelo método de extração por fenol e clorofórmio. O método de extração por fenol e clorofórmio já foi utilizado com sucesso para Archaea (Santoro et al., 2014). O perfil eletroforético do gel de agarose revelou bandas de alta massa molecular com concentrações variando entre $2,2 \mathrm{ng} / \mu \mathrm{l}$ e $22 \mathrm{ng} / \mu \mathrm{l}$ aproximadamente, com exceção da amostra S04, onde não foi observada a presença de DNA. Porém, ensaios de PCR realizados com esta amostra geraram fragmentoso do tamanho esperado, sugerindo que a concentração de DNA desta amostra estaria muito baixa, dificultando a sua visualização em gel de agarose corado com brometo de etídio (figura 19).

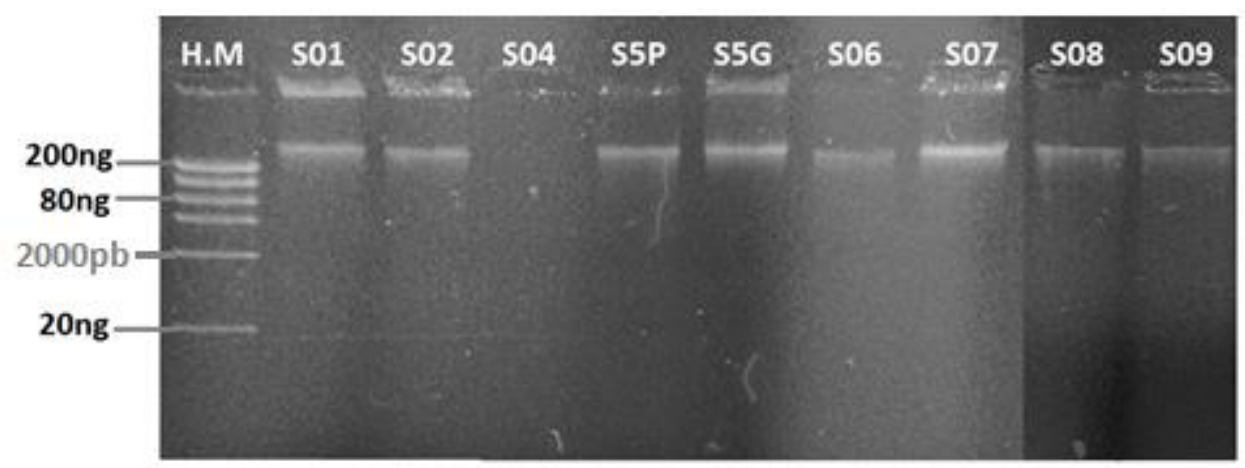

Figura 19. Perfil eletroforético em agarose $1 \%$ corado com Brometo de etídio da extração por fenol/clorofórmio do DNA total das colônias em meio sólido. H.M. = marcador de massa molecular High Mass Ladder $4 \mu \mathrm{L}$ (Invitrogen). 
Para a extração de DNA das culturas em meio líquido, o conteúdo dos tubos foi centrifugado e o pellet resultante foi submetido à extração por fenol/clorofórmio. A análise em gel de agarose revelou presença de DNA em todas amostras, porém em baixa concentração, como pode ser verificado na Figura 20.

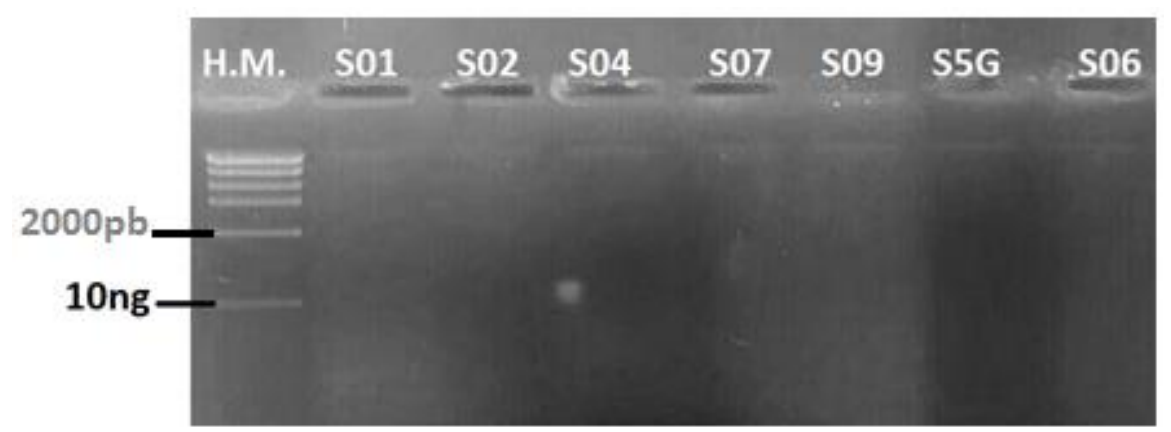

Figura 20. Perfil eletroforético em agarose $1 \%$ corado com Brometo de etídio da extração por fenol/clorofórmio do DNA total das colônias em meio líquido. H.M. = marcador de massa molecular High Mass Ladder (Invitrogen).

\subsubsection{Ensaios de PCR dirigidos aos genes de rRNA 16S e da enzima amônia monoxigenase A (amoA) de Archaea.}

Os ensaios de PCR para o gene de rRNA16S de Archaea foram realizados com os DNAs das colônias em meio sólido com concentrações entre 1 e 5 ng para cada amostra, resultando na amplificação de fragmentos de DNA no tamanho esperado para todas as amostras em pelo menos uma das concentrações (fotos não apresentadas). Os fragmentos foram então reunidos e purificados, a fim de se obter uma maior concentração final de DNA para cada amostra. O perfil eletroforético da purificação está exibido na figura 21. 

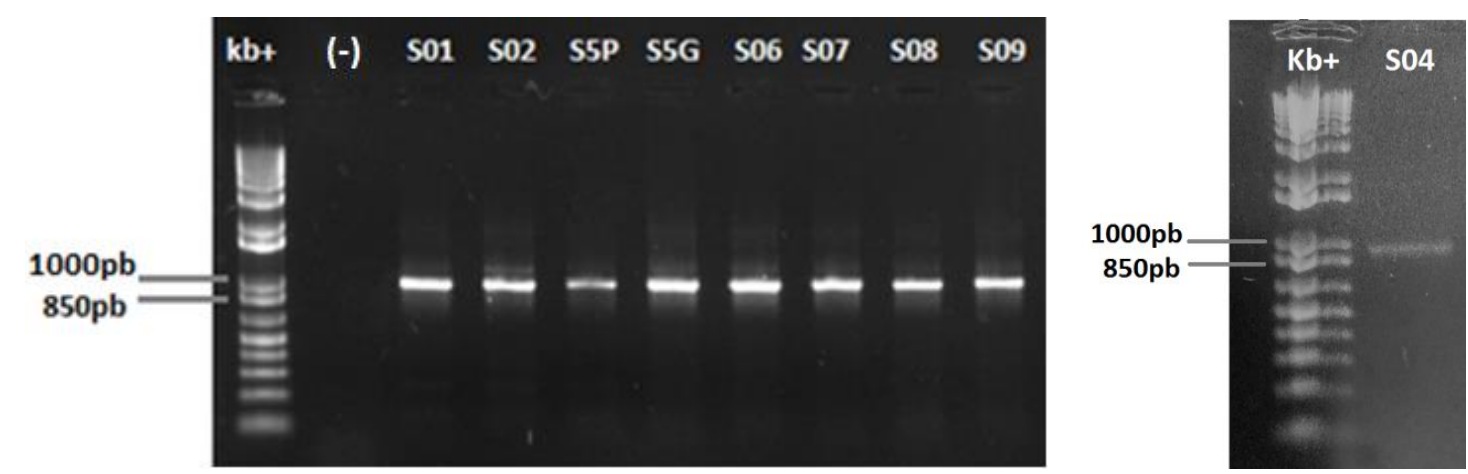

Figura 21. Perfil eletroforético em gel agarose $1 \%$ corado com brometo de etídio dos produtos de PCR para o gene 16S de Archaea, a partir do DNA extraído das diferentes colônias. Kb+ = Marcador $1 \mathrm{~Kb}$ Plus ladder (Invitrogen). (-) = controle negativo onde o DNA foi substituído por água na reação.

A PCR realizada com os iniciadores para o gene amoA e com as mesmas concentrações utilizadas nos ensaios para o gene rRNA 16S resultou na amplificação de fragmentos com tamanho esperado para todas as amostras. As amostras foram então reunidas e purificadas e o resultado analisado em gel de agarose pode ser observado na figura 22.

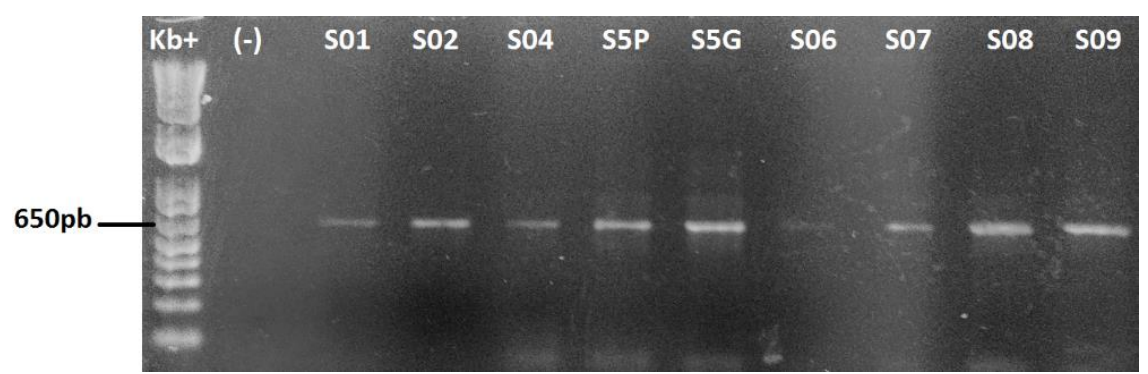

Figura 22. Perfil eletroforético em gel de agarose $1 \%$ corado com brometo de etídio da PCR para o gene amoA, a partir do DNA das colônias. Kb+ = Marcador $1 \mathrm{~Kb}$ Plus ladder (Invitrogen). (-) = controle negativo onde o DNA foi substituído por água DNA na reação.

Também foram feitos ensaios com os iniciadores que amplificam fragmentos do gene de rRNA 16S do domínio Bacteria a fim de se confirmar a presenças de membros deste domínio nas culturas. Os ensaios de PCR revelaram a presença de produtos de tamanho esperado (cerca de 1400pb) em todas as amostras, confirmando a ocorrência de um co-cultivo de bactérias e archaeas em todas as culturas obtidas (Figura 23). 


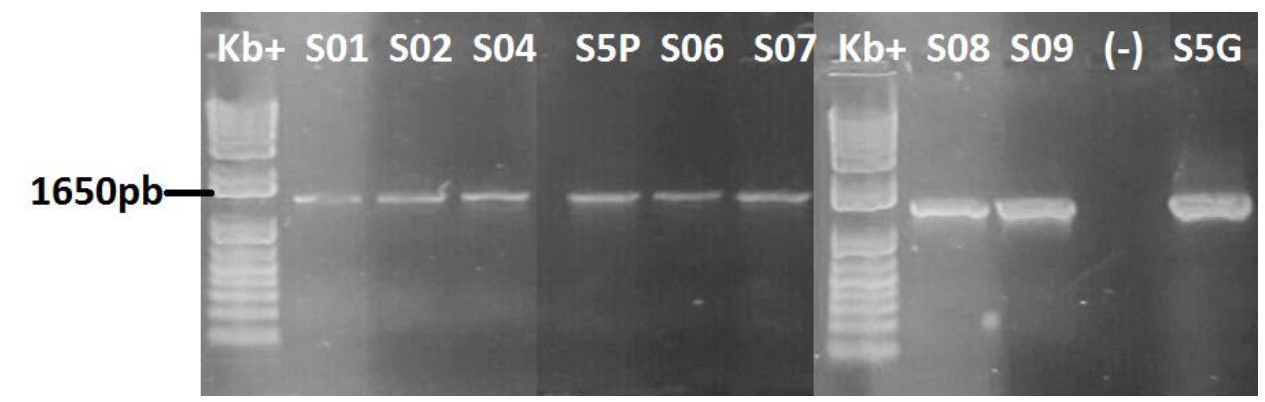

Figura 23. Perfil eletroforético em gel de agarose $1 \%$ corado com brometo de etídio da PCR para o gene de rRNA $16 \mathrm{~S}$ de Bacteria $\mathbf{K b +}=$ Marcador $1 \mathrm{~Kb}$ Plus ladder (Invitrogen). $(-)=$ controle negativo, onde o DNA foi substituído por água na reação.

Para as culturas em meios líquidos, foram realizados ensaios de PCR com os mesmos três pares de iniciadores, empregando-se diferentes concentrações de DNA destas amostras. Os resultados obtidos confirmaram a ocorrência de um co-cultivo nas culturas líquidas, bem como o potencial nitrificante das archaeas presentes (Figura 24). O ensaio de PCR com o par 21F/958R revelou bandas pouco intensas em algumas amostras, de difícil visualização em gel de agarose (Figura 24a). Visto que estes experimentos foram realizados em fevereiro de 2016, os produtos de PCR obtidos não foram ainda submetidos à clonagem, sequenciamento de DNA e análises de bioinformática, a fim de se obter uma melhor caracterização destas culturas. 

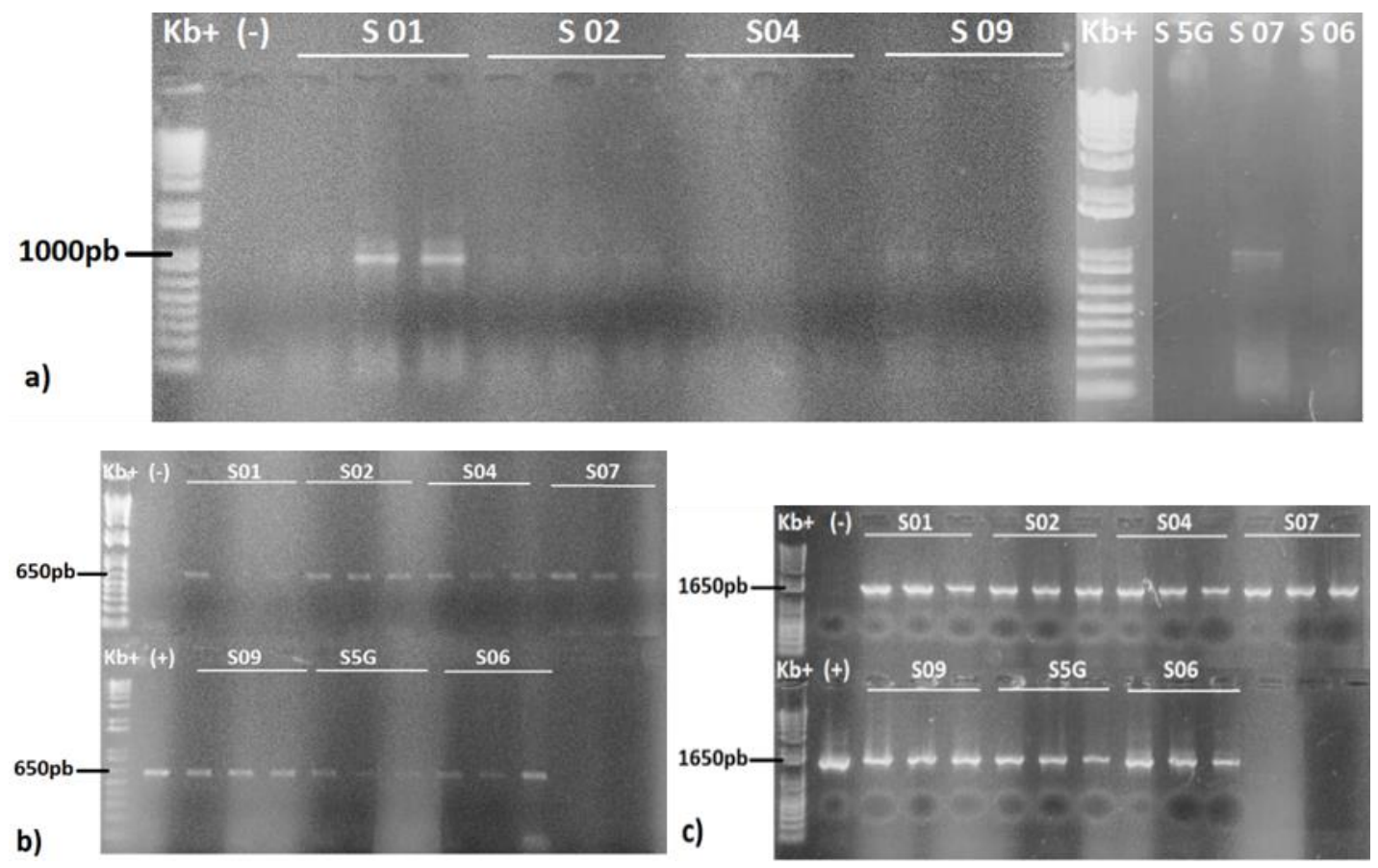

Figura 24. Perfil eletroforético em gel de agarose $1 \%$ corado com brometo de etídio da PCR empregando o DNA extraído das culturas em meio líquido para (a) o gene de rRNA $16 \mathrm{~S}$ de Archaea, (b) amoA e (c) gene de rRNA 16S de Bacteria. Kb+ = Marcador $1 \mathrm{~Kb}$ Plus ladder (Invitrogen). (-) = controle negativo, onde o DNA foi substituído por água na reação. $(+)=$ controle positivo, onde foi usado DNA total do sedimento para a amplificação de genes de Archaea (a e b) e DNA de Salmonella sp., para a amplificação do gene de rRNA16S de Bacteria (c).

\subsubsection{Transformação células de $E$. coli DH5a e seleção de clones recombinantes.}

Os DNAs relativos aos genes amoA e de rRNA $16 \mathrm{~S}$ de Bacteria foram submetidos a sequenciamento automático, sem qualquer etapa prévia de clonagem, enquanto os fragmentos do gene de rRNA $16 \mathrm{~S}$ de Archaea foram primeiramente ligados ao vetor pGEM-T Easy e transformados, por choque térmico, em células de E.coli DH5 $\alpha$. Foram selecionados 194 clones recombinantes, assim distribuídos: 24 clones de cada uma das oito amostras e dois clones da amostra "S04", cujo sistema de transformação apresentou baixíssima eficiência. As células foram inoculadas em meio LB líquido contendo ampicilina e incubadas por uma noite a $37^{\circ} \mathrm{C}$ em estufa, sendo uma alíquota de cada clone estocada em glicerol $35 \%$, a $-20^{\circ} \mathrm{C}$. 


\subsubsection{Extração de DNA plasmidial}

Os 194 clones obtidos na transformação tiveram o seu DNA plasmidial extraído por lise alcalina. A análise do perfil eletroforético do DNA extraído em gel de agarose revelou que o processo apresentou diferentes graus de eficiência, com algumas amostras apresentando significativo grau de degradação do DNA e outras, com baixa eficiência no processo de extração (Figura 25).

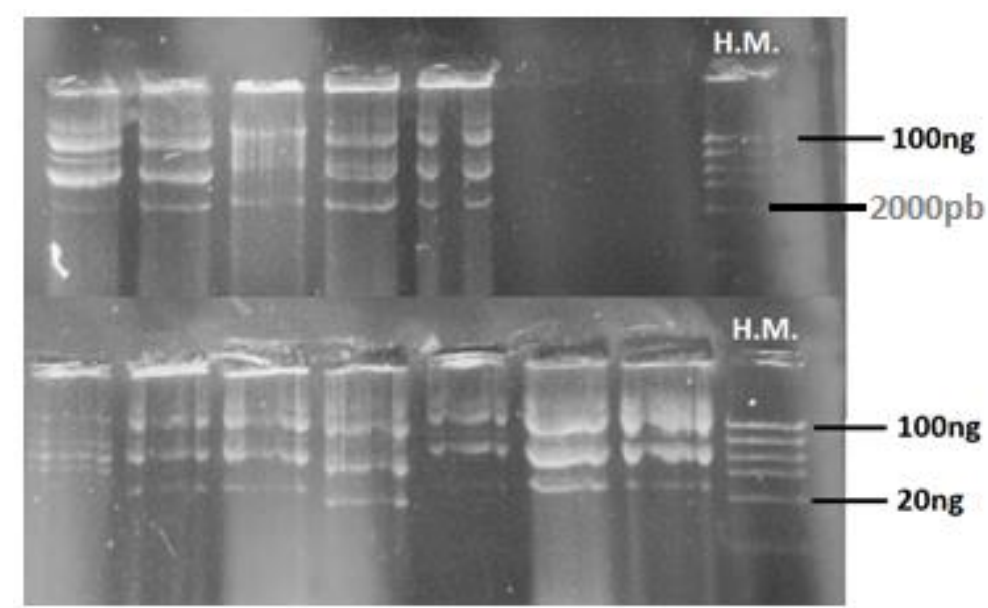

Figura 25. Perfil eletroforético em gel de agarose $1 \%$ corado com brometo de etídio da extração de DNA plasmidial de clones recombinantes aleatórios, contendo parte do gene de rRNA $16 \mathrm{~S}$ de Archaea . H.M. = Marcador de massa molecular High Mass Ladder (Invitrogen).

\subsubsection{Sequenciamento automático de DNA.}

O DNA plasmidial dos 194 clones recombinantes, relativos as nove amostras, foram submetidos ao sequenciamento automático de DNA utilizando o iniciador 21F. Das 194 sequências, 77 foram eliminadas por apresentarem valor de PHRED (Ewing et al., 1998) inferior a 20 para 250 bases. Outras cinco sequências foram eliminadas devido à ausência de similaridade quando alinhadas às demais sequências, quando analisadas no BioEdit, ou por não apresentarem identidade com o domínio Archaea quando comparadas com o banco de dados. Assim, foram analisadas 112 sequências, relativas as nove amostras. O número de sequências analisadas para cada amostra está relacionado na Tabela 9. 
Tabela 9. Número de sequências utilizadas nas análises de bioinformática para cada amostra das colônias em meio sólido.

\begin{tabular}{cc}
\hline Colônias & $\mathbf{N}^{\circ}$ de sequências \\
\hline S 01 & 13 \\
S 02 & 14 \\
S 04 & 2 \\
S 5P & 7 \\
S 5G & 13 \\
S 06 & 11 \\
S 07 & 7 \\
S 08 & 23 \\
S 09 & 22 \\
\hline
\end{tabular}

A baixa qualidade do sequenciamento evidenciada pela exclusão de um alto número de sequências (40\% do total) com um valor de PHRED menor que 20, pode ter sido decorrente de problemas na extração de DNA plasmidial.

\subsubsection{Análises de Bioinformática.}

\subsection{Analises do gene de rRNA $16 \mathrm{~S}$}

Para analisar a presença de bactérias nas culturas, os amplicons obtidos para o gene de rRNA 16S de Bacteria, foram sequenciados e suas sequências foram classificadas de acordo com o banco de dados do Greengenes com o auxílio do programa Mothur e o resultado revelou que todas as colônias consistiam em um cocultivo de diferentes archaeas com um tipo distinto de bactéria. As análises indicaram a ocorrência de quatro gêneros de bactérias, sendo 3 da família Burkholderiaceae e 1 da família Brucellaceae, demonstrando que, apesar da tentativa de eliminação das bactérias por meio da adição de agentes antimicrobianos e a filtração das culturas em filtros 0,45mm, estas se encontram estáveis no cultivo, não sendo possível a sua eliminação das culturas até o momento. 
Tabela 10. Famílias e Gêneros de bactérias encontradas nas placas do cultivo.

\begin{tabular}{ccc}
\hline Colônias & Família & Gênero \\
\hline S 01 & Brucellaceae & Ochrobactrum \\
S 02 & Brucellaceae & Ochrobactrum \\
S 04 & Burkholderiaceae & Ralstonia \\
S 5P & Burkholderiaceae & Burkholderia \\
S 5G & Burkholderiaceae & Burkholderia \\
S 06 & Burkholderiaceae & Cupriavidus \\
S 07 & Burkholderiaceae & Ralstonia \\
S 08 & Burkholderiaceae & Ralstonia \\
S 09 & Burkholderiaceae & Ralstonia \\
\hline
\end{tabular}

O gênero Ochrobactrum, membro da família Brucellaceae foi estabelecido em 1988 (Holmes et al., 1988) e pertence à classe das alfa-proteobactérias. Membros deste gênero foram caracterizados como bacilos Gram-negativos, aeróbios obrigatórios, móveis e positivos para redução de nitrato ( $\mathrm{Li}$ et al., 2015) e têm sido encontrados em diversos ambiententes como: solo (Lebuhn et al. 2000), plantas e rizoplanos (Tripathi et al. 2006; Zurdo-Piñeiro et al. 2007; Imran et al. 2010), ambientes industriais (Huber et al. 2010), animais (Kämpfer et al., 2011) e humanos (Velasco et al. 1998; Kämpfer et al. 2007; Teyssier et al. 2007).

O gênero Burkholderia, que pertence à classe das beta-proteobacterias, foi criado em 1992 para agrupar 7 espécies pertencentes ao grupo das Pseudomonas (Yabuuchi et al., 1992). Este gênero, com 40 espécies descritas (Seo et al., 2015), caracteriza-se pela versatilidade metabólica, uma vez que são capazes de crescer a partir da utilização de 200 compostos orgânicos distintos (Maltseva et al., 1999). Estes organismos estão frequentemente associados a plantas e animais (Harazono et al., 2003; Compant et al., 2005; Tian et al., 2013) sendo também encontrados em diversos ambientes, tais como solos (Draghi et al., 2014; Liu et al., 2014), sistemas de tratamento de esgoto (Lu et al., 2012), águas e hospitais (Vial et al., 2007; Compant et al., 2008) e podem estar associados a fixação de nitrogênio em solos (Tran Van et al., 2000)

Em 1995, dois membros de Burkholderia e uma espécie de Alcaligenes foram reclassificados, em um novo gênero, denominado Ralstonia (Yabuuchi et al. 1995). Este 
gênero contém bacilos gram-negativos aeróbios e não fermentadores, que podem ser encontrados em solos e ambientes aquáticos. Algumas espécies possuem importância clínica, sendo associadas a diferentes processos infecciosos (Ryley \& Weaver, 1975; Ryan \& Adley, 2014). O genoma de uma linhagem de $R$. solanacearum, espécie tipicamente encontrada em plantas, parece codificar uma via completa de denitrificação, que inclui uma $\mathrm{NO}_{3}{ }^{-}$redutase (narG), $\mathrm{NO}_{2}{ }^{-}$redutase (aniA) e $\mathrm{NO}$ redutase (norB) (Dalsing et al., 2015).

Assim como a re-classisifcação de tipos de Burkholderia em 1995, em 2004, uma linhagem de Ralstonia foi descrita como um novo gênero, denominado Cupriavidus (Vaneechoutte et al., 2004; Vandamme \& Coenye, 2004). Atualmente este gênero contém 14 espécies que habitam diversos ambientes como solo, água, nódulos de leguminosas e humanos (Vandamme et al. 2004; Sato et al. 2006; Cuadrado et al. 2010; Estrada-de los Santos et al. 2012; Martínez-Aguilar et al. 2012). Vários organismos deste gênero são comumente encontrados em solos e raízes de leguminosas e são consideradas bactérias fixadoras de nitrogênio (Estrada-de los Santos et al., 2014).

Todas as bactérias encontradas nas culturas de archaeas são típicas de solos e ambientes aquáticos e parecem ter um papel no ciclo do nitrogênio complementar às archaeas nitrificantes, a fixação do nitrogênio atmosférico ou a denitrificação. Com isso, é possível que as archaeas e bactérias presentes no cultivo se encontrem em simbiose no ambiente, exibindo uma co-dependência metabólica, o que poderia explicar a dificuldade de eliminar as bactérias da cultura.

Em relação as archaeas obtidas no cultivo, as 112 sequências dos clones recombinantes contendo fragmentos do gene de rRNA 16S de Archaea foram alinhadas no programa Clustal X, editadas no programa BioEdit e classificadas com base no banco de dados Greengenes com o auxílio do programa Mothur, a fim de obter uma descrição das archaeas presentes nas diferentes culturas. Foram observados 5 grupos taxonômicos diferentes com $100 \%$ de identidade para as nove amostras do cultivo (tabela 11). 
Tabela 11. Número de sequências de rRNA 16S afiliadas aos diferentes grupos de Archaea para cada amostra do cultivo, de acordo com o banco de dados Greengenes.

\begin{tabular}{ccccccc}
\hline Culturas & $\begin{array}{c}\mathbf{N}^{\mathbf{o}} \mathbf{d e} \\
\text { seq. }\end{array}$ & $\begin{array}{c}\text { 1.1a } \\
\text { Cenarchaeales(o) }\end{array}$ & $\begin{array}{c}\text { 1.1b } \\
\text { Nitrososphaera(g) }\end{array}$ & $\begin{array}{c}\text { 1.1c } \\
\text { NRP-J(o) }\end{array}$ & $\begin{array}{c}\text { MCG } \\
\text { pGrfC26(o) }\end{array}$ & $\begin{array}{c}\text { Methanomicrobia } \\
\text { Methanosarcina(g) }\end{array}$ \\
\hline S 01 & 13 & 0 & 3 & 0 & 8 & 2 \\
S 02 & 14 & 1 & 0 & 2 & 11 & 0 \\
S 04 & 2 & 0 & 0 & 0 & 2 & 0 \\
S 5P & 7 & 0 & 0 & 0 & 5 & 2 \\
S 5G & 13 & 1 & 0 & 0 & 10 & 2 \\
S 06 & 11 & 0 & 1 & 0 & 8 & 2 \\
S 07 & 7 & 0 & 0 & 0 & 5 & 2 \\
S 08 & 23 & 0 & 3 & 1 & 15 & 4 \\
S 09 & 22 & 0 & 1 & 0 & 17 & 4 \\
\hline Total & $\mathbf{1 1 2}$ & $\mathbf{2}(1,80 \%)$ & $\mathbf{8}(7,14 \%)$ & $\mathbf{3}(2,67 \%)$ & $\mathbf{8 1}(72,32 \%)$ & $\mathbf{1 8}(16,07 \%)$ \\
\hline
\end{tabular}

É interessante notar que, apesar das colônias apresentarem um aspecto morfológico homogêneo, aparentemente elas são formadas por mais de uma archaea e uma bactéria. Este fato também foi observado em um experimento de cultivo de archaeas a partir de solo do cerrado realizado pelo nosso grupo de pesquisa.

Ao analisar os grupos encontrados nas diferentes culturas obtidas, observa-se a presença destes mesmos grupos na amostra do sedimento que deu origem ao cultivo, isto é: a classe Methanomicrobia, o recém proposto filo Bathyarchaeota (MCG), os grupos I.1a e I.1c de Thaumarchaeota, além de um grupo que não foi detectado na amostra do sedimento: o grupo I.1b de Thaumarchaeota. Este grupo foi anteriormente considerado um subgrupo do grupo I de Crenarchaeota mesófilas, em conjunto com os grupos previamente citados I.1a e I.1c (DeLong, 1998), os quais passaram a ser posicionados no filo Thaumarchaeota (Pester et al., 2011). Este grupo é considerado típico de diferentes tipos de solos (Bintrim et al., 1997; Bates et al., 2011) e possui alguns membros cultivados, como Nitrososphaera viennensis e Canditatus Nitrososphaera gargensis. Foram encontradas 8 sequências das culturas afiliadas a este grupo, representando $7,14 \%$ do total e apresentando $100 \%$ de identidade com o gênero Nitrososphaera de acordo com a classificação baseada no banco de dados do Greengenes.

A diferença no número de sequências analisadas para cada amostra impossibilitou uma comparação real dos organismos cultivados, não sendo possível afirmar que as colônias contêm somente os organismos representados pelas sequências 
obtidas. Um novo experimento de transformação para a obtenção de novos clones seria necessário para uma real caracterização das archaeas presentes no cultivo. Entretanto, é possível sugerir que o grupo MCG se encontre presente de forma substancial no cultivo, tendo em vista que foi observado uma maior quantidade de sequências pertencentes a este grupo (72,32\% do total), as quais foram observadas em todas as amostras do cultivo.

Para se estimar o número de OTUs presentes nas culturas em meio sólido, as 112 sequências foram alinhadas e as OTUs representativas foram obtidas com o auxílio do programa Mothur. A análise dos resultados revelou que as diferentes OTUs encontradas para cada grupo taxonômico estão distribuídas de forma aleatória nas 9 amostras do cultivo (Tabela 12), não sendo possível realizar uma relação entre os diferentes tipos de archaeas encontrados em cada colônia e sua morfologia.

Tabela 12. Diferentes OTUs encontradas com o índice de $97 \%$ de similaridade, alinhadas com o banco de dados Greengenes, para cada amostra do cultivo em meio sólido. NRP-J = grupo 1.1c. Sagma-X = grupo 1.1a.

\begin{tabular}{|c|c|c|c|c|c|c|c|c|c|c|}
\hline OTUs & $\mathrm{N}^{\circ}$ seq. & S 01 & S 02 & S 04 & S 5P & S 5G & S 06 & S 07 & S 08 & S 09 \\
\hline S5G_20 (MCG) & 35 & $\mathrm{X}$ & $\mathrm{X}$ & -- & -- & $\mathrm{X}$ & $\mathrm{X}$ & $\mathrm{X}$ & $\mathrm{X}$ & $X$ \\
\hline S1_06 (MCG) & 16 & $\mathrm{X}$ & $\mathrm{X}$ & -- & $X$ & $\mathrm{X}$ & $\mathrm{X}$ & -- & $\mathrm{X}$ & -- \\
\hline S9_04 (MCG) & 10 & $\mathrm{X}$ & $\mathrm{X}$ & -- & -- & $X$ & -- & -- & $\mathrm{X}$ & $\mathrm{X}$ \\
\hline S7_23(MCG) & 4 & -- & -- & -- & $\mathrm{X}$ & -- & -- & $\mathrm{X}$ & -- & $\mathrm{X}$ \\
\hline S9_16(MCG) & 3 & $\mathrm{X}$ & -- & -- & -- & -- & -- & -- & -- & $\mathrm{X}$ \\
\hline S5P_21 (MCG) & 3 & -- & -- & -- & $X$ & -- & -- & -- & -- & $X$ \\
\hline S2_06 (MCG) & 2 & -- & $\mathrm{X}$ & -- & -- & -- & -- & $\mathrm{X}$ & -- & -- \\
\hline $\mathrm{S} 1 \_10(\mathrm{MCG})$ & 2 & $X$ & -- & -- & -- & -- & -- & -- & -- & $\mathrm{X}$ \\
\hline S4_02 (MCG) & 2 & -- & -- & $\mathrm{X}$ & -- & -- & -- & -- & -- & -- \\
\hline S5P_19 (MCG) & 1 & -- & -- & -- & $\mathrm{X}$ & -- & -- & -- & -- & -- \\
\hline S9_10 (MCG) & 1 & -- & -- & -- & -- & -- & -- & -- & -- & $\mathrm{X}$ \\
\hline S1_23 (MCG) & 1 & $X$ & -- & -- & -- & -- & -- & -- & -- & -- \\
\hline S6_13 (MCG) & 1 & -- & -- & -- & -- & -- & $\mathrm{X}$ & -- & -- & -- \\
\hline S8_02 (Methanosarcina) & 18 & $\mathrm{X}$ & -- & -- & $\mathrm{X}$ & $\mathrm{X}$ & $\mathrm{X}$ & $\mathrm{X}$ & $\mathrm{X}$ & $\mathrm{X}$ \\
\hline S8_18 (Nitrososphaera) & 5 & $\mathrm{X}$ & -- & -- & -- & -- & $\mathrm{X}$ & -- & $\mathrm{X}$ & -- \\
\hline S9_03 (Nitrososphaera) & 1 & -- & -- & -- & -- & -- & -- & -- & -- & $\mathrm{X}$ \\
\hline S1_14 (Nitrososphaera) & 1 & $\mathrm{X}$ & -- & -- & -- & -- & -- & -- & -- & -- \\
\hline S1_21 (Nitrososphaera) & 1 & $\mathrm{X}$ & -- & -- & -- & -- & -- & -- & -- & -- \\
\hline S2_21 (NRP-J) & 2 & -- & $\mathrm{X}$ & -- & -- & -- & -- & -- & -- & -- \\
\hline S8_23 (NRP-J) & 1 & -- & -- & -- & -- & -- & -- & -- & $\mathrm{X}$ & -- \\
\hline S2_20 (Sagma-X) & 2 & -- & $\mathrm{X}$ & -- & -- & $\mathrm{X}$ & -- & -- & -- & -- \\
\hline Total & 112 & 10 & 6 & 1 & 5 & 5 & 5 & 4 & 6 & 9 \\
\hline
\end{tabular}


Foram encontradas 13 OTUs relacionadas ao grupo MCG, 4 associadas ao grupo I.1b - gênero Nitrososphaera, 2 OTUs afiliadas ao grupo 1.1c e para o grupo I.1a e o gênero Methanosarcina, foram associadas apenas uma OTU em cada. Para o grupo I.1a, esta OTU foi encontrada apenas na placa S 02 sendo representada por 2 sequências, enquanto a OTU do gênero Methanosarcina representa 18 sequências encontradas em 7 das 9 amostras do cultivo e foi o único organismo do filo Euryarchaeota presente nas culturas em meio sólido.

A presença de organismos pertencentes ao gênero Methanosarcina é curioso, visto que as archaeas metanogênicas são consideradas anaeróbias restritas (Zeikus, 1977) e as culturas deste trabalho não foram armazenadas em condições de anaerobiose, o que pode sugerir que os organismos presentes na cultura se encontrem associadas em um padrão que gera uma condição de anaerobiose em seu interior, possibilitando o crescimento de organismos metanogênicos.

Com o intuito de comparar as sequências obtidas no sedimento do córrego Roncador e no cultivo em laboratório, as sequências provenientes do cultivo e do sedimento total foram agrupadas e foi realizado um alinhamento múltiplo entre elas. A partir deste, foram confeccionados diagramas de Venn utilizando o coeficiente de similaridade de 97\% com o auxílio do programa Mothur, onde é possível observar as OTUs a nível de espécie presentes nas culturas, no sedimento e as compartilhadas entre elas (figura 26). 


\section{$97 \%$}

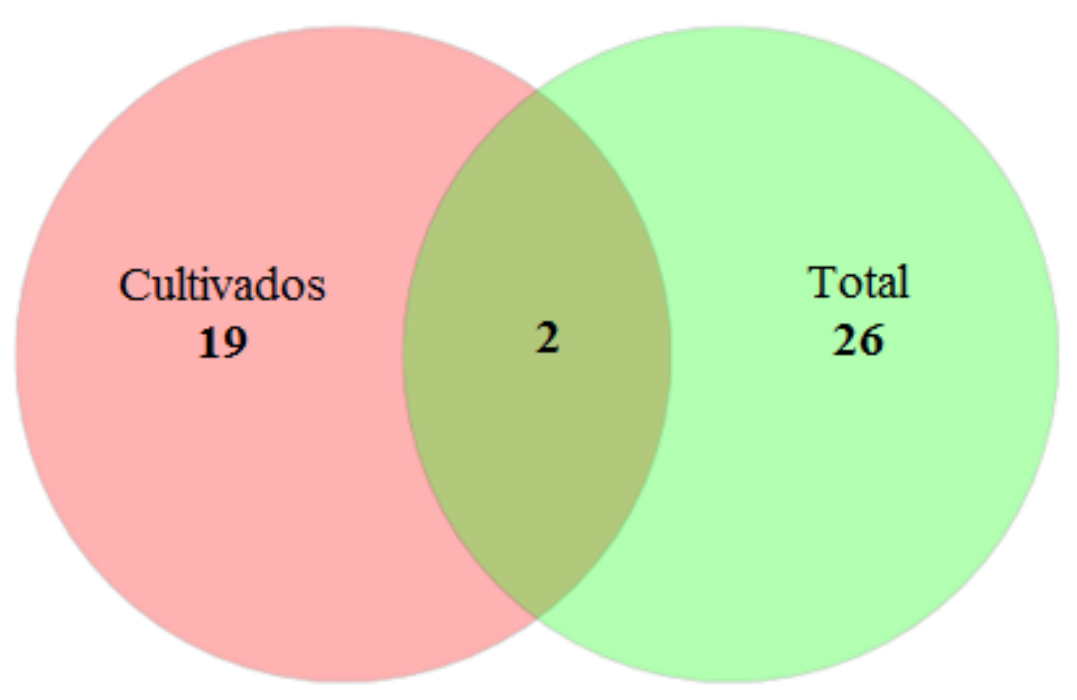

Figura 26. Diagrama de Venn representando as OTUs compartilhadas entre as sequências do gene rRNA $16 \mathrm{~S}$ de Archaea obtidas a partir do cultivo e o sedimento do córrego Roncador, empregando o índice de similaridade de $97 \%$.

A figura 26 representa o número de OTUs para o nível de espécie do cultivo e sedimento. Nela é possível observar que existem 19 OTUs únicas do cultivo, 26 apresentadas somente pelo sedimento e apenas 2 OTUs compartilhadas entre eles. Destas 2 OTUs, uma representa 2 sequências do cultivo e 2 do sedimento que estão afiliadas ao grupo I.1a de Thaumarchaeota, e a outra está afiliada ao grupo MCG, representando 2 sequências do cultivo e uma do sedimento.

A ausência de sequências afiliadas ao grupo I.1b na amostra do sedimento que originou o cultivo, bem como o número de OTUs a nível de espécie pertencentes somente a amostra do cultivo, pode estar associada ao baixo número de sequências obtidas para esta amostra, resultando em uma cobertura estimada de 58\% para este índice de similaridade.

Apesar de uma grande diferença na quantidade de sequências obtidas para o cultivo e o sedimento, ao comparar as sequências das duas amostras, é possível perceber uma diferença na representatividade dos grupos taxonômicos entre elas. $\mathrm{Na}$ amostra referente ao cultivo, existe uma predominância de sequências associadas ao grupo MCG, com 13 das 21 OTUs pertencentes a este grupo, incluindo a OTU mais representativa do cultivo: A OTU S5G_20 que representa 35 sequências. Já com a 
amostra referente ao sedimento, as sequências se encontram mais distribuídas entre os diferentes grupos. Entretanto, o grupo com o maior número de sequências afiliadas a ele foi o filo Thaumarchaeota, estando dentro deste filo a OTU mais representativa do sedimento, a N17, representando 10 sequências em um total de 48 sequências obtidas para esta amostra. Essa diferença de representatividade pode estar relacionada com a abundância dos organismos em cada amostra. Os ensaios de PCR são baseados em uma reação enzimática de caráter competitivo, onde DNAs mais abundantes na amostra terão uma maior possibilidade de ser amplificado (Forney et al., 2004). Sendo assim, podemos especular que o meio de cultura utilizado neste trabalho, bem como as condições de cultivo estabelecidas no laboratório, pode favorecer o crescimento de archaeas pertencentes ao grupo MCG, visto que foi o grupo mais abundante nas amostras do cultivo e aparentemente não se encontra na amostra do sedimento com a mesma representatividade.

Com o resultado do sequenciamento, que exibiu culturas mistas entre bactérias e tipos diferentes de archaeas, não foi possível estabelecer uma relação entre as archaeas encontradas e as características macroscópicas das placas. Entretanto, foi possível estabelecer uma provável relação entre os tipos coloniais das placas e a bactéria presente no co-cultivo. Placas com o tipo A possuem bactérias do gênero Ochrobactrum, as placas com os tipos coloniais B e E contém em sua cultura bactérias do gênero Ralstonia, a placa com o tipo C contem bactérias do gênero Cupriavidus e as placas com o tipo D, possuem o gênero de bactéria Burkholderia.

\subsection{Análises com o gene amoA.}

Os amplicons obtidos nos ensaios de PCR para o gene da subunidade A da enzima amônia monoxigenase de Archaea (amoA) foram purificados e enviados diretamente para sequenciamento automático. As sequências obtidas foram alinhadas no programa CulstaX, editadas com o programa BioEdit e analisadas quanto a sua similaridade de sequências com o programa Mothur. Foi utilizado o índice de similaridade de $97 \%$ e foram encontradas 3 OTUs representativas das placas do cultivo (tabela 13). 
Tabela 13. Sequências das OTUs representativas para o gene amoA de Archaea das placas de cultivo e as placas que elas representam.

\begin{tabular}{cc}
\hline OTUs rep. & Culturas \\
\hline amo S 04 & S 02 e S 04 \\
amo S 5P & S 5P \\
amo S 09 & S 01, S 5G, S 06, S 07, S 08 e S 09 \\
\hline
\end{tabular}

Com as análises das sequências referentes ao gene amoA de Archaea, foram detectadas sequências referentes a AOAs em todas as culturas estudadas. As archaeas com potencial para oxidação de amônia descritas até o momento estão associadas aos grupos I.1a e I.1b do filo Thaumarchaeota. Ao analisar as sequências referentes ao gene rRNA 16S de Archaea das culturas, foram observados membros deste grupo em apenas quatro das nove culturas. Porém, como mencionado anteriormente, o número de sequências obtidas não possibilita uma descrição completa das archaeas presentes no cultivo, podendo existir organismos oxidantes de amônia nas culturas que não foram detectados nas análises para o gene de rRNA 16S. Além disso, podemos sugerir que as AOAs presentes se encontram em menor quantidade em relação as outras archaeas do cultivo, devido ao caráter competitivo da reação da PCR já mencionado anteriormente.

Também foram realizados no programa Mothur, diagramas de Venn com as sequências referentes ao gene $a m o A$ do cultivo e do sedimento a fim de comparar a comunidade de archaeas nitrificantes do sedimento com as archaeas presentes no cultivo (Figura 27) e foi observado que, para o índice de similaridade de 97\%, somente uma das 3 OTUs presentes no cultivo foi encontrada na amostra do sedimento. Esta OTU compartilhada representa as culturas S02 e S04. A cobertura de 73\% para o nível de espécie das sequências do sedimento pode explicar a ausência das duas OTUs únicas ao cultivo na amostragem da comunidade do sedimento. 


\section{$97 \%$}

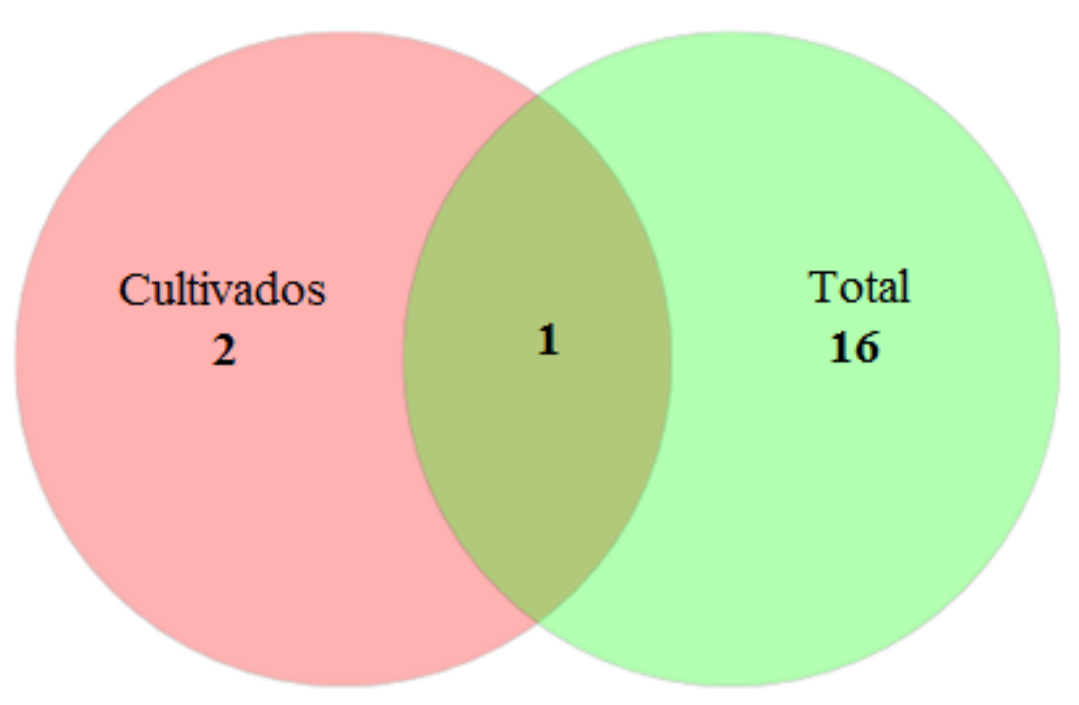

Figura 27. Diagrama de Venn representando as OTUs compartilhadas entre as amostras do gene amoA de Archaea do cultivo em meio sólido e o sedimento do córrego roncador para o índice de similaridade de $97 \%$.

\subsubsection{7. Árvores filogenéticas}

A árvore filogenética é uma representação gráfica da semelhança genética entre as diferentes espécies ou entidades biológicas, sendo o método de representação das relações evolutivas mais utilizado pela comunidade científica. Existem vários critérios utilizados para construir uma árvore filogenética, porém todos partem de um mesmo princípio: a análise múltipla das sequências selecionadas (Yang et al., 2008). Todas as árvores deste trabalho foram criadas pelo programa MEGA5 (Tamura et al., 2011) empregando-se o método estatístico Maximum-likelihood (máxima verossimilhança), que apresentou um melhor agrupamento das sequências selecionadas, com o modelo Tamura-Nei e teste de filogenia bootstrap com 1000 réplicas.

O resultado obtido com as sequências do gene de rRNA 16S de Archaea, oriundas dos clones recombinantes sugere que o cultivo é composto por vários membros deste domínio, formando uma pequena comunidade. Por esta razão, uma árvore filogenética foi construída a fim de analisar as relações evolutivas entre os diferentes organismos presentes no cultivo. Para a construção desta árvore foi realizado o alinhamento múltiplo das sequências obtidas das placas de cultura, do sedimento do córrego e sequências de organismos isolados e não cultivados previamente descritas. 
Foram utilizadas sequências que representavam as diferentes OTUs encontradas no cultivo com o índice de $97 \%$ de similaridade. As sequências representativas da comunidade do sedimento também foram adicionadas utilizando o mesmo índice, a fim de comparar as relações evolutivas entre as duas amostras. Todavia, as OTUs representadas por singletons foram excluídas, visando a obtenção de uma árvore de visualização mais fácil.

As sequências de isolados de Archaea que foram utilizadas para a construção das árvores foram obtidas no banco de dados do NCBI e alinhadas com as sequências provenientes deste trabalho. Para o filo Euryarchaeota foram escolhidos os organismos Methanosarcina acetivorans, Methanosarcina horoborensis e Methanosaeta thermofila. Para o filo Crenarchaeota foram selecionadas sequências dos organismos Sulfolobus solfactaricus, Thermoproteus neutrofilus, Ignicoccus pacificus, Ignisphaera aggregans, Fervidicoccus fontis e Caldisphaera lagunensis.

O antigo grupo I de Crenarchaeota é atualmente classificado por muitos autores como pertencentes ao filo Thaumarchaeota, sendo esta a classificação deste grupo considerada durante este trabalho. Os membros escolhidos deste filo para as análises evolutivas foram: Cenarchaeum symbiosum, Nitrosopumilus maritimus, Candidatus Giganthauma insulaporcus, Candidatus Giganthauma karukerense, Nitrosotalea devanaterra - que representam o grupo I.1a e Candidatus Nitrososphaera gargensis, Nitrososphaera viennensis - representando o grupo I.1b. Além destes organismos, foi incluído o único representante cultivado do grupo Hot Water Crenarchaeotic Group III, também considerado um grupo integrante do filo Thaumarchaeota (Spang et al., 2010; Pester et al., 2011), Candidatus Nitrosocaldus yellowstonii.

Até o momento, não existem organismos cultivados do grupo I.1c de Thaumarchaeota e do grupo MCG, novo filo proposto Bathyarchaeota, sendo representados na árvore por sequências de organismos não cultivados, disponíveis no banco de dados do NCBI. Visando um melhor entendimento a respeito das relações evolutivas dos organismos obtidos em nossas culturas, sequências de archaeas não cultivadas consideradas próximas às sequências do cultivo, segundo a ferramenta BLAST (Altschul et al., 1990) do NCBI, também foram incluídas na construção da árvore filogenética. 


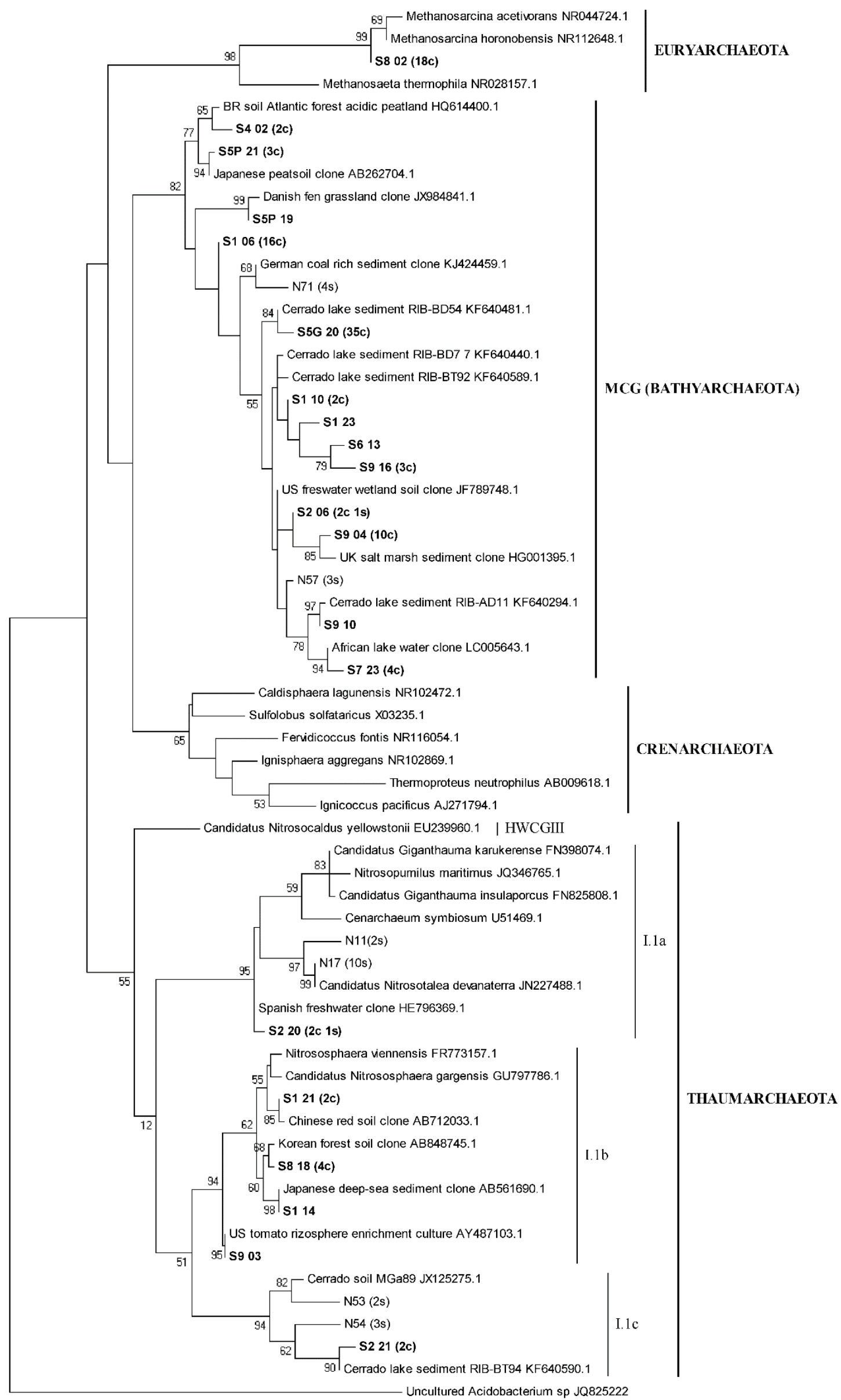


Figura 28. Árvore filogenética construída pelo método Maximum-likelihood, modelo Tamura-Nei e teste de bootsrap 1000x a partir do fragmento do gene de rRNA 16S das OTUs $(97 \%)$ representativas do cultivo e do sedimento alinhadas com archaeas isoladas e não cultivadas dos filos Crenarchaeota, Thaumarchaeota, Bathyarchaeota e Euryarchaeota, Os valores indicados entre parênteses ao lado de cada nome indicam o número de sequências do cultivo (c) e sedimento (s) representadas pela OTU. Seuquências sem valores de representatividade são singletons. O grupo externo é uma bactéria do genêro Acidobacterium ainda não cultivada. A barra de escala indica a distância de similaridade entre os ramos. Valores de bootstrap inferiores a 50 foram excluídos da árvore. HWCGIII = Hot Water Crenarchaeotic Group III.

Ao alinharmos as sequências do cultivo e do sedimento, foram geradas 21 OTUs do cultivo, sendo 20 usadas na construção da árvore; e 28 OTUs do sedimento, sendo apenas seis usadas na construção da árvore, por serem representadas por mais de uma sequência. Destas seis OTUs, duas se associaram ao grupo MCG (filo Bathyarchaeota) e quatro ao filo Thaumarchaeota, sendo que a OTU mais representativa do sedimento N17 - formada por 10 sequências, se encontrou fortemente associada à archaea nitrificante Nitrosotalea devanaterra.

Ao analisar a árvore construída, observa-se que a maioria das OTUs referentes às archaeas cultivadas distribuíram-se no filo Bathyarchaeota (MCG), seguido do grupo I.1b de Thaumarchaeota; filo Euryarchaeota e os grupos I.1a e I.1c de Thaumarchaeota. Este resultado do alinhamento está de acordo com a classificação realizada previamente pelo banco de dados Greengenes. Pode-se observar que nenhuma sequência do cultivo ou do sedimento foi classificada no filo Crenarchaeota.

Apenas uma OTU, representada por 18 sequências originadas das archaeas cultivadas, foi associada ao filo Euryarchaeota, se afiliando ao gênero Methanosarcina, resultado semelhante ao encontrado pela classificação com o banco de dados. Como já mencionado anteriormente, a presença de metanogênicas em sedimentos límnicos é comum e está associada à grande quantidade de matéria orgânica e baixa disponibilidade de oxigênio nesses ambientes (Torres et al., 2010).

O grupo MCG ainda não possui qualquer membro cultivado e já foi identificado em vários ambientes terrestres e aquáticos, de várias profundidades, com posicionamento instável na árvore filogenética (Pester et al., 2011; Kubo et al., 2012). Vários trabalhos utilizando tecnologias independentes de cultivo em relação a este grupo vem sendo realizados e revelam possíveis informações acerca das características fisiológicas deste grupo. Em 2014, Meng e colaboradores sugeriram a possibilidade 
deste grupo realizar a degradação de compostos aromáticos e, em 2015, Evans e colaboradores sugeriram, a partir da reconstrução do genoma de duas archaeas associadas a este grupo, a presença de genes envolvidos no metabolismo de metano. A ampla distribuição e os possíveis metabolismos de MCG, sugerem que este grupo possua um importante papel nos ciclos biogeoquímicos, mas a falta de organismos cultivados tem limitado o conhecimento acerca de suas propriedades fisiológicas e relações evolutivas (Meng et al., 2014).

Ao comparar as sequências representativas deste grupo com sequências previamente identificadas no banco de dados do NCBI, foi observado que as sequências que possuíam maior identidade com as sequências do cultivo foram identificadas em diversos ambientes tais como lagos, sedimentos e diferentes tipos de solos. Foram identificadas 13 OTUs do cultivo e duas do sedimento pertencentes a este grupo. Dentre elas, se encontra a OTU representada pela sequência S2_06, que também foi encontrada no sedimento do córrego roncador. Um fato interessante foi a associação da OTU representada pela sequência SG_20, a mais representativa do cultivo - com 35 sequências, a um clone encontrado no sedimento da lagoa da Bacia baixo Inhacica, no bioma Cerrado (Cerrado lake sediment RIB-BT54 - No. de acesso KF640481.1; Rodrigues et al., 2014), além de outras três OTUs que também foram associadas a sequências deste mesmo sedimento. Isto pode indicar que o grupo MCG se encontra presente em diferentes sedimentos límnicos do Cerrado.

O grupo I.1c de Thaumarchaeota vem sendo identificado tipicamente em ambientes de solos ácidos, por metodologias independentes de cultivo (Jurgens et al., 1997; Kemmitz et al., 2007; Bomberg \& Timonen, 2009), não possuindo qualquer representante cultivado até o momento. Todas as sequências afiliadas a este grupo encontradas neste trabalho, se associaram a sequências obtidas em ambientes do Cerrado. Podemos dar destaque a OTU representada pela sequência do cultivo S2_21, que também foi encontrada no sedimento e apresentou $99 \%$ de identidade com um clone de sedimento de lagoa do Cerrado (Cerrado lake sediment RIB-94- No. de acesso KF640590.1; Rodrigues et al., 2014). Uma OTU do cultivo, representada pela sequência S8_23, afiliada a este grupo, apresentava uma ramificação duvidosa quando adicionada na construção da árvore, com o nível de bootstrap muito baixo e, por esse motivo, foi excluída das análises evolutivas. Porém, esta sequência possui $99 \%$ de identidade com uma sequência encontrada em solo de Mata da Galeria do Cerrado 
(clone MGaA80, No. de acesso JX125269.1; Catão et al., 2013) de acordo com a ferramenta BLAST e quando inseridas na árvore, as duas sequências se posicionavam em um clado único.

O grupo I.1b de Thaumarchaeota, considerado típico de solos (Bintrim et al., 1997; Bates et al., 2011), possui alguns organismos descritos que foram cultivados em culturas de enriquecimento (Simon et al., 2005; Kim et al., 2012; Xu et al., 2012) e um representante obtido em cultura pura: Nitrososphaera viennensis, isolada de solo de Viena - Áustria (Stieglemeier et al., 2014). Todas as OTUs do cultivo encontradas para este grupo foram associadas ao gênero Nitrososphaera, a partir da classificação com o banco de dados do Greengenes. Porém, na árvore filogenética se encontraram mais próximas a sequências de organismos não cultivados do que com as sequências representantes deste gênero.

O grupo I.1a de Thaumarchaeota é comumente descrito em ambientes aquáticos, a maioria marinhos (Preston et al., 1996; Könneke et al., 2005; Muller et al., 2010), com um representante isolado de um solo agriculturável (Lehtorvita-Morley et al.,2011). Apenas uma OTU do cultivo foi afiliada a este grupo, a qual foi representada por duas sequências do cultivo e uma do sedimento. Esta OTU se afiliou mais proximamente a um representante não cultivado encontrado em ambiente de água doce da Espanha (Spanish freshwater clone HE796369.1), formando um clado com ramificação basal em relação aos representantes isolados deste grupo.

Ao comparar os resultados das análises de bioinformática das sequências relativas ao gene de rRNA $16 \mathrm{~S}$ com as microscopias realizadas a partir das colônias obtidas, não foi possivel estabelecer qualquer relação entre as archaeas e o tipo morfológico observado nas micrografias. As archaeas do gênero Methanosarcina são descritas como aglomerados de pequenos cocos (Sowers et al., 1984), os quais não foram observados nas imagens de MEV. Tal resultado pode sugerir que estas archaeas estejam em menor quantidade nas colônias. De acordo com os relatos da literatura, as archaeas mesófilas cultivadas até o momento aparentam ter formatos bacilares, com tamanhos entre 0,5 e $1 \mu \mathrm{m}$ (Lehtorvirta-Morley et al., 2014; Jung et al., 2014) ou cocos irregulares diminutos, com até $1 \mu \mathrm{m}$ de diâmetro (Kim et al., 2012; Stieglmeier et al., 2014). Porém, estes organismos são representantes apenas dos grupos I.1a e I.1b de Thaumarchaeota e quando as sequências destes organismos são alinhadas aos organismos obtidos em cultura neste trabalho, estas se encontram relacionadas mas em 
clados separados. Além disso, não há qulaquer descrição sobre a morfologia dos organismos do grupo 1.1c de Thaumarchaeota e de MCG até o momento, devido à falta de organismos cultivados.

Representantes de Thaumarchaeota, detectados tanto nas culturas como na comunidade do sedimento, estão associados ao ciclo do nitrogênio e podem ter importante papel ecológico em diversos ambientes (Offre et al., 2013). Neste filo se encontram organismos com a capacidade de oxidação de amônia, como os membros dos gêneros Nitrososphaera, grupo I.1b, Nitrosopumilus e Nitrosotalea do grupo I.1a (Lehtorvita-Morley et al.,2011; Spang et al., 2014; Zhalnina et al., 2014) e Nitrosocaldus do grupo Hot water Crenarchaeotic Group III (HWCGIII) (De la Torre et al., 2008) que estão representados na árvore (figura 28). Até o momento, nenhum representante do grupo I.1c foi associado a este metabolismo.

Para analisar as relações evolutivas dos organismos oxidantes de amônia encontrados neste trabalho, a sequências representativas obtidas para o gene da amônia monoxigenase A de Archaea do cultivo e do sedimento foram utilizadas juntamente com sequências deste gene de organismos nitrificantes isolados do filo Thaumarchaeota para a construção de uma árvore filogenética. Também foram utilizadas sequências de organismos não cultivados que apresentaram alto grau de identidade com as sequências obtidas neste trabalho. A árvore foi construída com os mesmos parâmetros utilizados para a árvore do gene de rRNA 16s (Maximum-likelihood, Tamura-Nei e Bootsrap 1000x). 


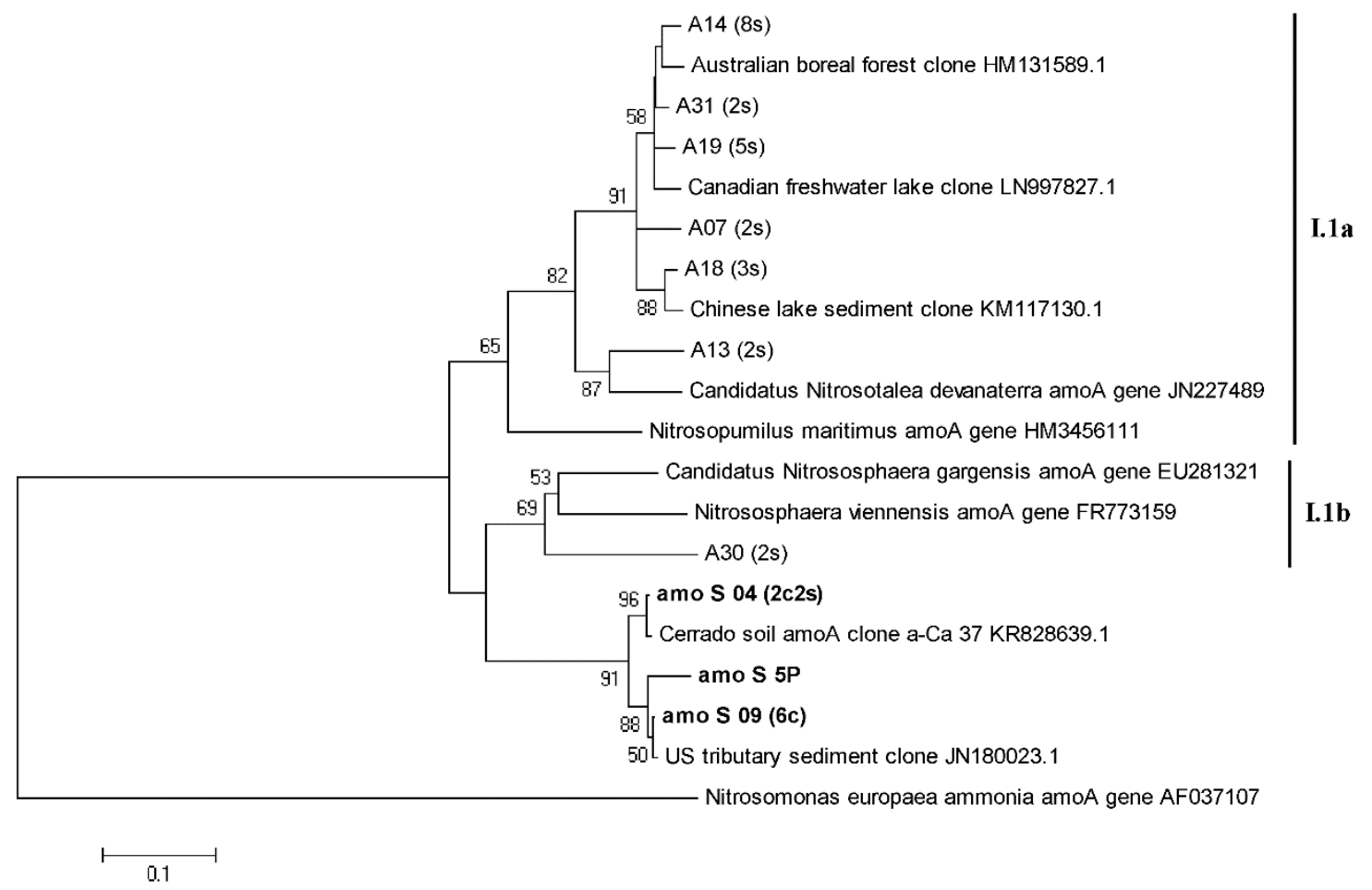

Figura 29. Árvore filogenética construída pelo método Maximum-likelihood, modelo Tamura-Nei e teste de bootsrap 1000x a partir do fragmento do gene amoA de Archaea das OTUs (97\%) representativas do cultivo e do sedimento alinhadas com archaeas isoladas do filo Thaumarchaeota e archaeas ainda não cultivadas. Os valores indicados entre parênteses ao lado de cada nome indicam o número de sequências do cultivo (c) e sedimento (s) representadas pela OTU. Sequências sem valores de representatividade são singletons. Para grupo externo, foi utilizado o gene amoA da bactéria Nitrosomonas europaea. A barra de escala indica a distância de similaridade entre os ramos. Valores de bootstrap inferiores a 50 foram excluídos da árvore.

Ao analisar a árvore pode-se verificar que a maioria das sequências obtidas a partir do sedimento foram associadas ao grupo I.1a, sendo afiliadas em sua maioria com organismos ainda não cultivados encontrados em solos, água doce e sedimentos. Apenas uma OTU se encontrou mais próxima ao organismo Candidatus Nitrosotalea devanaterra, isolada de solos agriculturáveis ácidos e relatada como uma oxidante de amônia acidófila obrigatória (Lehtorvita-Morley et al., 2011). Este resultado é interessante quando comparado à árvore do gene rRNA $16 \mathrm{~S}$, onde uma OTU que representa 10 sequências do sedimento também foi associada a esta archaea. Outro fato interessante foi a presença de sequências do sedimento que se afiliaram ao grupo I.1b, visto que não foram encontradas sequências do gene de rRNA $16 \mathrm{~S}$ do sedimento afiliadas a este grupo. Este fato evidencia a necessidade da obtenção de mais sequências 
do sedimento para uma melhor cobertura e descrição da comunidade de Archaea presente no córrego Roncador.

As sequências representativas do cultivo foram distribuídas na árvore próximo ao grupo I.1b, porém nenhuma teve associação próxima aos representantes cultivados deste grupo - Nitrososphaera viennensis e Canditatus Nitrososphaera gargensis formando um clado irmão com ramificação basal a elas, resultado semelhante ao ocorrido com as sequências do gene de rRNA $16 \mathrm{~S}$ do cultivo. Vale ressaltar que a OTU representada pela sequência amo $\mathrm{S}$ 04, que também representa uma sequência encontrada no sedimento, foi fortemente afiliada com um clone obtido em solo do Cerrado em um trabalho realizado pelo nosso grupo de pesquisa (Cerrado soil amoA clone a-Ca37, No de acesso KR828639.1. Dias, 2015). Neste trabalho, foi observado que esta sequência correspondia a uma OTU bastante representativa no solo do cerrado que, quando analisada na árvore filogenética, também se agrupava em um clado distinto, não associado a qualquer um dos grupos conhecidos. Este fato permite sugerir a possível existência de archaeas com o potencial de oxidação de amônia ainda não descritas. 


\section{Considerações Finais}

Os resultados obtidos neste trabalho evidenciam o potencial do cultivo de archaeas oriundas de sedimentos límnicos do Cerrado em meios artificiais que mimetizam as condições naturais do ambiente, sendo possível a obtenção de diferentes tipos de archaeas associadas em um co-cultivo com bactérias. Análises de testes de fluorescência com hibridização in situ (FISH) poderão fornecer informações importantes sobre a proporção entre as archaeas e as bactérias presentes nas diferentes culturas. O uso de novas metodologias tais como experimentos de diluição à extinção, enriquecimento dos meios de cultura com diferentes compostos e o uso de novos antibióticos poderão auxiliar na separação das archaeas em culturas puras, trazendo um maior entendimento acerca das características morfológicas e fisiológicas destes organismos.

O estabelecimento das culturas em meio líquido abre as portas para a realização de uma série de experimentos que não são possíveis com as culturas em meio sólido, como o estabelecimento de curvas de crescimento, condições ótimas de temperatura e $\mathrm{pH}$ e a resposta dos organismos a diferentes compostos adicionados, permitindo uma melhor caracterização dos organismos cultivados.

A realização de novos experimentos de sequênciamento do DNA tanto das culturas quanto dos sedimentos do córrego Roncador são necessários para a realização de um estudo de filogenia molecular mais robusto das duas amostras e, em relação às amostras do cultivo, este estudo é importante para a confimação da classificação das archaeas cultivadas em laboratório.

A obtenção de culturas de archaeas dos grupos I.1c de Thaumarchaeota e MCG, poderão trazer maiores informações sobre as características morfológicas destes grupos e o seu possível papel no ambiente. 


\section{Conclusões}

- Foram obtidas culturas de Archaea dos filos Euryarchaeota, Thaumarchaota e Bathyarchaeota (MCG) a partir de amostras de sedimentos da camada recente de deposição do córrego Roncador da Reserva ecológica do IBGE (Recor) em Brasília-DF.

- Todas as colônias obtidas consitem em co-cultivos de diferentes archaeas e bactérias das famílias Brucellacae ou Burkholderiacae.

- Algumas archaeas cultivadas possuem o potencial de oxidação de amônia.

- As análises filogenéticas sugerem que a comunidade presente no sedimento do córrego Roncador é rica com uma variedade de diferentes tipos de archaea. 


\section{Referências bibliográficas}

Albers, S. V. \& Meyer, B. H. (2011). The archaeal cell envelope. Nature Reviews Microbiology, 9(6):414-426.

Amann, R. I.; Ludwig, W.; Schleifer, K. H. 1995. Phylogenetic identification and in situ detection of individual microbial cells without cultivation. Microbiological Reviews, 59(1):143-169.

Antony, C.P.; Murrell, J.C.; Shouche, Y.S. (2011). Molecular diversity of methanogens and identification of Methanolobus sp. as active methylotrophic Archaea in Lonar crater lake sediments. FEMS microbiology ecology, 1-9.

Araújo, J. F.; Castro, A. P.; Costa, M. M. C.; Togawa, R.C.; Pappas, G. J.; Quirino, B. F.; Bustamante, M. M. C.; Williamson, L.; Handelsman, J.; Krüger, R. H. 2012. Characterization of soil bacterial assemblies in Brazilian savanna-like vegetation reveals acidobacteria dominance. Microbial Ecology, 64(3):760-770

Auchtung, T.A.; Takacs-Vesbach C.D.; Cavanaugh, C.M. (2006). "16S rRNA phylogenetic investigation of the candidate division "Korarchaeota"." Applied and Environmental Microbiology 72(7): 5077-5082.

Auguet, J.C.; Nomokonova, N.; Camarero, L. Casamayor, E.O. (2011). Seasonal changes of freshwater ammonia-oxidizing archaeal assemblages and nitrogen species in oligotrophic alpine lakes. Applied and Environmental Microbiology. 77:1937-45

Auguet, J.C.; Triado-Margarit, X.; Nomokonova, N.; Camarero, L.; Casamayor, E.O. (2012).Vertical segregation and phylogenetic characterization of ammoniaoxidizing Archaea in a deep oligotrophic lake The ISME Journal 6; 1786-1797

Balch, W. E.; Fox, G. E.; Magrum, L. J.; Woese, C. R.; Wolfe, R. S. (1979). Methanogens: reevaluation of a unique biological group. Microbiological Reviews, 43(2):260-296.

Barker, H. A. (1936). Studies upon the methane-producing bacteria. Laboratory of Microbiology, Technical University, Delft, Holland.)

Barns, S. M.; Delwiche, C. F.; Palmer, J.D.; Pace, N.R. (1996). Perspectives on archaeal diversity, thermophily and monophyly from environmental rRNA sequences. Proceedings of the National Academy of Science of USA, 93(17):9188-9193.

Barros, R. (2007) "Medidas de Diversidade Biológica" PGECOL - Universidade Federal de Juiz de Fora, Disponível em http://acszanzini.net/DISCIPLINAS_2012/ARDB\%202012\%201\%20TXT/MEDIDAS\%20DE\%20DIVERSIDADE\%20BIOLOGICA.pdf.

Bates, S. T.; Berg-Lyons, D.; Caporaso, J. G.; Walters, W. A.; Knight, R.; Fierer, N. (2011). Examining the global distribution of dominant archaeal populations in soil. The ISME journal, 5(5):908-917.

Belay, N. Mukhopadhyay, B.; De Macario, E.C.; Galask, R.; Daniels, L. (1990) "Methanogenic bacteria in human vaginal samples". Journal of Clinical Microbiology, 28(7): 1666-1668. 
Beman, J. M. \& Francis, C. A. (2006). Diversity of ammonia-oxidizing archaea and bacteria in the sediments of a hypernutrified subtropical estuary: Bahía del Tóbari, Mexico. Applied and Environmental Microbiology, 72(12):7767-7777.

Bhattarai, S.; Ross, K.; Schmid, M.; Anselmetti, F.S.; Bürgmann, H. (2012) Local conditions structure unique archaeal communities in the anoxic sediments of meromictic lake Kivu. Microbial Ecology 2012;64:291-310

Biddle JF, Lipp JS, Lever MA, Lloyd KG, Sørensen KB, Anderson R et al. (2006). Heterotrophic Archaea dominate sedimentary subsurface ecosystems off Peru. Proceedings of the National Academy of Sciences USA 103: 3846-3851.

Bintrim, S.B.; Donohue, T.J.; Handelsman, J.; Roberts, G.P.; Goodman, R.M. (1997). Molecular phylogeny of Archaea from soil. Proceedings of the National Academy of Sciences USA, 94:277-282.

Blainey, P. C.; Mosier, A. C.; Potanina, A.; Francis, C. A.; Quake, S. R. (2011). Genome of a low-salinity ammonia-oxidizing archaeon determined by single-cell and metagenomic analysis. PloS one, 6(2): e16626.

Blöchl, E.; Rachel, R.; Burggraf, S.; Hafenbradl, D.; Jannasch, H.W.; Stetter, K.O. (1997).Pyrolobus fumarii, gen. and sp. nov., represents a novel group of archaea, extending the upper temperature limit for life to $113^{\circ} \mathrm{C}$. Extremophiles, 1:14-21.

Bomberg, M.; Timonen, S. (2009). Effect of tree species and mycorrhizal colonization on the archaeal population of boreal forest rhizospheres. Applied and Environmental Microbiology. 75:308-15.

Borrel, G.; Lehours, A. C.; Crouzet, O.; et al. (2012). Stratification of Archaea in the deep sediments of a freshwater meromictic lake: vertical shift from methanogenic to uncultured archaeal lineages. PLoS One. 7: e43346

Bresolin, J. D.; Bustamante, M. M. C.; Krüger, R. H.; Silva, M. R. S. S.; Perez, K. S. 2010. Structure and composition of bacterial and fungal community in soil under soybean monoculture in the Brazilian Cerrado. Brazilian Journal of Microbiology, 41:391-403

Brisou, J.; Courtois, D.; Denis, F. (1974). Microbiological study of a hypersaline lake in french Somaliland. Applied Microbiology, 27:819-822

Brochier, C.; Gribaldo, S.; Zivanovic, Y.; Confalonieri, F.; Forterre, P. 2005. Nanoarchaea: representatives of a novel archaeal phylum or a fast-evolving euryarchaeal lineage related to Thermococcales? Genome Biology, 6(5):R42.

Brochier-Armanet, C.; Boussau, B.; Gribaldo, S.; Forterre, P. (2008). Mesophilic Crenarchaeota: proposal for a third archaeal phylum, the Thaumarchaeota. Nature Reviews Microbiology, 6(3):245-252.

Brochier-Armanet, C.; Forterre, P.; Gribaldo, S. (2011). Phylogeny and evolution of the Archaea: one hundred genomes later. Current opinion on Microbiology, 14(3): 274-281.

Bullock, C. (2000). The Archaea - a biochemical perspective. Biochemistry and Molecular Biology Education., 28:186-191. 
Bushwell, A. M. \& Neave, S. L. (1930). Laboratory studies of sludge digestion. State of Illinois department of registration and education, division of the state water survey. Bulletin No. 30 .

Buswell, A. M. \& Hatfield, W. D. (1930). Anaerobic fermetations. State of Illinois department of registration and education, division of the state water survey. Bulletin No. 32.

Cabello, P.; Roldan, M.D.; Moreno-Vivian, C. (2004). Nitrate reduction and the nitrogen cycle in archaea. Microbiology 150:3527-46

Calvó, L.; Cortey, M.; García-Marín, J.; Garcia-Gil, L. (2005) "Polygenic analysis of ammonia-oxidizing bacteria using $16 \mathrm{~S}$ rDNA, amoA, and $a m o B$ genes". International Microbiology 8(2): 103-110.

Canfield, D. E.; Glazer, A. N.; Falkowski, P. G. (2010). The evolution and future of Earth's nitrogen cycle. Science, 330(6001):192-196.

Castro, A. P.; Quirino, B. F.; Pappas, G.; Kurokawa, A. S.; Neto, E; L.; Krüger, R. H. 2008. Diversity of soil fungal communities of Cerrado and its closely surrounding agriculture fields. Archives of Microbiology, 190:129-139.

Catão, E.; Castro, A. A.;Barreto, C. C.; Kruger, R. H.; Kyaw, C. M. (2013). Diversity of Archaea in Brazilian savanna soils. Archives in Microbiology. published online: 21 March of 2013. DOI 10.1007/s00203-013-0882-x.

Chaban, B.; Ng, S.Y.M.; Jarrell, K.F. (2006). Archaeal habitats - from the extreme to the ordinary. Can. J. Microbiol., 52:73-116.

Compant, S.; Reiter, B.; Sessitsch, A.; Nowak, J.; Clément, C.; E. Ait Barka, E. (2005). Endophytic colonization of Vitis vinifera L. by plant growth-promoting bacterium Burkholderia sp. strain PsJN. Applied and Environment Microbiology. 71:1685-1693.

Compant, S.; Nowak, J.; Coenye, T.; Clément, C.; Ait Barka, E. (2008). Diversity and occurrence of Burkholderia spp. in the natural environment. FEMS Microbiology Reviews.;32:607-26.

Connon, S.A. \& Giovannoni, S.J. (2002). High-throughput methods for culturing microorganisms in very-low-nutrient media yield diverse new marine isolates. Applied and Environmental Microbiology., 68:3878-3885.

Conrad, R.; Phelps, T.J.; Zeikus, J.G. (1985). Methanogenic Bacteria in Sewage Sludge and Juxtaposition of Hydrogen-Producing and Gas Metabolism Evidence in Support of the Lake Sediments. Applied and Environmental Microbiology, 50(3): 595-601.

Dalsing, B.L.; Truchon, A.N.; Gonzalez-Orta, E.R.; Milling, A.S.; Allen,C. (2015). Ralstonia solanacearum Uses Inorganic Nitrogen Metabolism for Virulence, ATP Production, and Detoxification in the Oxygen-Limited Host Xylem Environment. mBio. 6(2): e02471-14. 
Darland, G.; Brock, T.D.; Samsonoff, W.; Conti, S.F. (1970). A thermophilic, acidophilic mycoplasma isolated from a coal refuse pile. Science, 170:1416-1418

Delmont, T.O.; Robe, P.; Cecillon, S.; Clark, I.M.; Constancias, F.; Simonet, P.; Hirsch, P.R.; Vogel, T.M. 2011. Accessing the Soil Metagenome for Studies of Microbial Diversity. Applied and Environmental Microbiology, 77(4): 1315-1324.

De Los Santos, P. E.; Solano-Rodriguez, R.; Matsumura-Paz, L.T.; Vasquez-Murieta, M.S. (2014). Cupriavidus plantarum sp. nov., a plant-associated species. Archives in Microbiology DOI 10.1007/s00203-014-1018-7

DeLong, E.F. (1992). Archaea in costal marine environments. Proceedings of the National Academy of Sciences. USA, 89:5685-5689.

DeLong, E.F.; Wu, K.Y.; Prézelin, B.B.; Jovine, R.V. (1994). High abundance of Archaea in Antartic marine picoplankton. Nature, 371:695-697.

DeLong, E. F. (1998). Everything in moderation: archaea as 'non-extremophiles'. Current Opinion in Genetetic \& Development, 8(6):649-654.

DeRosa, M.; Gambacorta, A.; Bu'lock, J.D. (1975). Extremely thermophilic acidophilic bacteria convergent with Sulfolobus acidocaldarius. Journal of Gen. Microbiol., $86: 156-164$.

DeRosa, M.; Trincone, A; Nicolaus, B.; Gambacorta, A. (1991). In: Life Under Extreme Conditions (diPrisco, G. ed). Berlin: Springer. p. 61-87.

Dennis, P.P. (1997). Ancient Ciphers: Translation in Archaea. Cell, 89: 1007-1010.

Dias A.B.A. (2015). Filogenia molecular e cultivo de Archaea de solos de cerrado Sensu stricto. Disseração de mestrado em Biologia Mloecular - Universidade de Brasília.

Dridi, B.; Raoult, D.; Drancourt, M. (2011). Archaea as emerging organisms in complex human microbiomes. Anaerobe, 17(2):56-63.

Eckburg, P. B.; Lepp, P.W.; Relman, D. A. 2003. Archaea and Their Potential Role in Human Disease. Infection and Immunity, 71(2):591-596.

Esteves, F.A. (2011). Sedimentos Límnicos. Fundamentos de limnologia, $3^{\text {a }}$ edição Interciência, Rio de Janeiro, p. 339-354

Ewing, B. \& Green, P. (1998). Base-calling of automated sequencer traces using phred II. Error probabilities. Genome Research, 8:186-194.

Fiala, G. \& Stetter, K.O. (1986). Pyrococcus furiosus sp. nov. represents a novel genus of marine heterotrophic archaebacteria growing optimally at $100^{\circ} \mathrm{C}$. Archives in Microbiology, 145:56-61l

Fillol, M.; Sanchez-Melsio, A.; Gich, F.; Borrego, C. M. (2015). Diversity of Miscellaneous Crenarchaeotic Group archaea in freshwater karstic lakes and their segregation between planktonic and sediment habitats. FEMS Microbiology Ecology. Vol. 91, No. 4 
Francis, C. A.; Roberts, K. J.; Beman J. M.; Santoro, A. E.; Oakley, B. B. (2005). Ubiquity and diversity of ammonia-oxidizing archaea in water columns and sediments of the ocean. Proc. Natl. Acad. Sci. USA. Oct 11;102(41):14683-8.

French, E.; Kozlowski, J. A.; Mukherjee, M.; Bullerjahn, G.; Bollmann, A. (2012). Ecophysiological Characterization of Ammonia-Oxidizing Archaea and Bacteria from Freshwater. Applied and Environmental Microbiology. Vol 78, No 16 p. $5773-5780$

Friedrich MW, Schmitt-Wagner D, Lueders T, Brune A. (2001). Axial differences in community structure of Crenarchaeota and Euryarchaeota in the highly compartmentalized gut of hte soil-feeding termite Cubitermes orthognathus. Applied and Environmental Microbiology 67: 4880-4890

Forterre, P.; Brochier, C.; Philippe, H. (2002). Evolution of the Archaea. Theoretical Population Biology 61, 409-422 doi:10.1006/tpbi.2002.1592

Fox, G. E.; Pechman, K. R.; Woese, C. R. (1977). Comparative cataloging of 16S ribosomal ribonucleic acid: molecular approach to procaryotic systematics. International Journal of Systematic Bacteriology, 27(1):44-57.

Fox, G. E.; Magrum, L. J.; Balch, W. E.; Wolfe, R. S.; Woese, C. R. (1977) Evolution Classification of methanogenic bacteria by $16 \mathrm{~S}$ ribosomal RNA characterization (comparative oligonucleotide cataloging/phylogeny/molecular evolution). Proceedings of the National Academy of Sciences USA 74,.10,.4537-4541

Fox, G.E.; Stcakebrandt, E.; Hespell, R.B.; Gibson, J.; Maniloff, G.J.; Dyer, T.A.; Wolfe, R.S.; Balch, W.E.; Tanner, R.S.; Magrum, L. J.; Zablen, L.B.; Blakemore, R.; Gupta, R.; Bonem L.; Lewis, B.J.; Stahl, D.A.; Luehrsen, K.R.; Chen, K.N.; Woese, C.R. (1980).The Phylogeny of Prokaryotes Science, vol. 209

Fuhrman, J.A.; McCallum, K.; Davis, A.A. (1992). Novel major archaebacterial group from marine plankton. Nature, 356:148-149.

Furtado, A.L.S.; Casper P.; Esteves, F.A. (2002). Methanogenesis in an impacted and dystrophic coastal lagoon (Macaé, Brazil). Brazilian Archives of Biology and Technology, 45(2)195-202

Gies, E.; Konwar, K. M.; Beatty, J. T.; et al. (2014). Illuminating microbial dark matter in meromictic Sakinaw Lake. Applied and Environmental Microbiology. 80 :6807-18.

Gloor, M; Wüest, A.; Münnich, M. (1994). Benthic boundary mixing and ressuspension induced by internal seiches. Hydrobiologia 284:59-68

Grohmann, D. \& Werner, F. (2011). Recent advances in the understanding of archaeal transcription. Current Opinion in Microbiology, 14(3):328-334.

Guy, L. \& Ettema, T.J.G. (2011) "The archael 'TACK' superphylum and the origin of eukaryotes”. Trends in Microbiology, 19(12): 580-587.

Handelsman, J. (2004). "Metagenomics: application of genomics to uncultured microorganisms". Microbiology and Molecular Biology Reviews, 68(4): 669685. 
Harazono, K.; Yamashita, N.; Shinzato, N.; Watanabe, Y.; T. Fukastu, T.; Kurane, R. (2003). Isolation and characterization of aromatics-degrading microorganisms from the gut of the lower termite Coptotermes formosanus. Bioscience Biotechnol Biochem 67:889-92.

Hartford, T.; Sneath, P.H.A. (1990) Experimental error in DNA-DNA pairing: a survey of the literature. Journal of Applied Bactreiology, 68, 527-542.

Herrmann M.; Hädrich, A.; Küsel, K.; (2012) "Predominance of thaumarchael ammonia oxidizing acidizer abundance and transcriptional activity in an acidic fen". Environmental Microbiology, 14(11): 3013-3025

Hershberger, K.L.; Barns, S.M.; Reysenbach, A.L.; Dawson, S.C.; Pace, N.R. (1996). Wide diversity of Crenarchaeota. Nature 384: 420

Hatzenpichler, R.; Lebedeva, E.V.; Spieck, E.; Stoecker, K.L.; Richter, A.; Daims, H.; Wagner, M. (2008) A moderately thermophilic ammonia-oxidizing crenarchaeote from a hot spring. Proceedings of the National Academy of Sciences USA, 105(6): 2134-2139.

Hong, Y.; Youshao, W.; Chen, F.; (2013) "Archaea dominate ammonia oxidizers in the permian water ecosystem of Midland basin". Microbes and Environments, 28(3): 396-199.

Huang, L.N.; Chen, Y.Q.; Zhou, H.; Luo, S.; Lan, C. Y.; Qu, L. H.(2003). Characterization of methanogenic Archaea in the leachate of a closed municipal solid waste landfill. FEMS Microbiology Ecology 46: 171-177

Huber, H.; Hohn, M.J.; Stetter, K.O.; Reinhard, R. 2003. A new phylum of Archaea represented by a nanosized hyperthermophilic symbiont. Nature, 417(6884):6367.

Inagaki, F.; Suzuki, M.; Takai, K.; Hanako, O,; Tatsuhiko, S.; Aoki, k.;Nealson, K. H.; Horikoshi, K. (2003) . Microbial Communities Associated with Geological Horizons in Coastal Subseafloor Sediments from the Sea of Okhotsk. Applied and Environmental

Microbiology.69(12):72247235.doi:10.1128/AEM.69.12.7224-7235.2003.

Ishino, Y. \& Ishino, S. (2012). Rapid progress of DNA replication studies in Archaea, the third domain of life. Science China, 55(5):386-403.

Jiang, H.; Dong, H.; Yu, B. et al.(2008). Dominance of putative marine benthic Archaea in Qinghai Lake, north-western China. Environmental Microbiology. 10:235567.

Jung, M. Y.; Park, S. J.; Min, D.; Kim, J. S.; Rijpstra, W. I. C.; Sinninghe Damsté, J. S.; Kim, G. J.; Madsen, E. L.; Rhee, S. K. 2011. Enrichment and characterization of an autotrophic ammonia-oxidizing archaeon of mesophilic crenarchaeal group I.1a from an agricultural soil. Applied and Environmental Microbiology, 77(24):8635-8647.

Jurgens, G.; LindstrÖm, K.; Saano, A. (1997). Novel group within the kingdom Crenarchaeota from boreal forest soil. Applied and Environmental Microbiology. 63:803-5. 
Kaeberlein, T.; Lewis, K.; Epstein, S.S. (2002). Isolating "uncultivable" microrganisms in pure culture in a simulated natural environment. Science, 296:1127-1129.

Kandler, O. \& Konig, H. (1998). Cell wall polymers in Archaea (Archaebacteria). Cell. Mol. Life Sci., 54:305-308.

Kasai Y, Takahata Y, Hoak T, Watanabe K. (2005).Physiological and molecular characterization of a microbial community established in unsaturated, petroleumcontaminated soil. Environ Microbiol 7:806-818

Kates, M. (1993). Membrane lipids of archaea. In: The Biochemistry of Archaea (Archaebacteria). Amsterdam: Elsevier. Capítulo 9, p. 261-295.

Kates, M.; Yenogouyan, L.S.; Sastry, P.S. (1965). A diether analog of phosphatidyl 29 glycerophosphate in Halobacterium cutirubrum. Biochim. Biophys. Acta, 98:252-268.

Kemnitz, D.; Kolb, S.; Conread, R. (2007) High abundance of Crenarchaeota in a temperate acidic forest soil. FEMS Microbiology Ecology. 60:442-8.

Khelaifia, S. \& Drancourt, M. 2012. Susceptibility of archaea to antimicrobial agentes: applications to clinical microbiology. Clinical Microbiology and Infection, 18(9): 841-848.

Kim, J.; Jung, M.; Park, S.; Rijpstra, I. C.; Damsté, J. S. A.; Madsen, E. L.; Min, D.; Kim, J.; Kim, G.; Rhee, S. 2012. Cutivation of a highly enriched ammoniaoxidizing archaeon of thaumarcheotal group I.1b from an agricultural soil. Environmental Microbiology, 14(6):1528-1543.

Klink, C. A. \& Machado, R. B. 2005. A conservação do Cerrado brasileiro. Megadiversidade, 1(1):147-155.

Könneke, M.; Bernhard, A. E.; de la Torre, J. R.; Walker, C. B.; Waterbury, J. B.; Stahl, D. A. 2005. Isolation of an autotrophic ammonia-oxidizing marine archaeon. Nature, 437(7058):543-546.

König H., Rachel R., Claus H. (2007). "Proteinaceous surface layers of archaea: ultrastructure and biochemistry," Archaea: Molecular and Cell Biology. (Washington, DC: American Society of Microbiology Press) 315-340.

Kubo, K.; Lloyd, K. G.; Biddle, J. F.; Amann, R.; Teske, A.; Knittel, K. (2012). Archaea of the Miscellaneous Crenarchaeotal Group are abundant, diverse and widespread in marine sediments. The ISME journal, 6(10):1949-1965.

Lane, D.J. (1991). Nucleic Acid Techniques in Bacterial Systematics. Eds Stackebrandt \& Goodfellow, 115-175.

Langworthy, T.A.; Smith, P.F.; Mayberry, W.R. (1972). Lipids of Thermoplasma acidophilum. Journal of Bacteriology, 112:1193-1200.

Lebedeva, E. V.; Hatzenpichler, R.; Pelletier, E.; Schuster, N.; Hauzmayer, S.; Bulaev, A.; Grigoreva, N. V.; Galushko, A.; Schmid, M.; Palatinszky, M.; Le Paslier, D.; Daims, H.; Wagner, M. (2013) "Enrichment and genome sequence of the group 
I.1a ammonia-oxidizing archaeon "Ca. Nitrosotenuis uzonensis" representing a clade globally distributed in thermal habitats". PloS One, 8(1): 1-12.

Lehtovirta-Morley, L. E.; Stoecker, K.; Vilcinkas, A.; Prosser, J. I.; Nicol, G.W. (2011). Cultivation of an obligate acidophilic ammonia oxidizer from a nitrifying acid soil. Proceedings of the National Academy of Sciences of USA, 108(38):1589215897.

Lehtovirta-Morley, L. E.; Ge, C.; Ross, J.; Yao, H.; Nicol, G. W.; Prosser, J. I. (2014). Characterisation of terrestrial acidophilic archaeal ammonia oxidisers and their inhibition and stimulation by organic compounds. FEMS Microbiology Ecology, 89:542-552.

Lehours, A. C.; Evans, P.; Bardot, C.; et al. (2007). Phylogenetic diversity of archaea and bacteria in the anoxic zone of a meromictic lake (Lake Pavin, France).Applied and Environmental Microbiology. 73:2016-9.

Leigh, J.A.; Albers, S.J.; Atomi, H. Allers, T. 2011. Model for genetics in the domain Archaea: methanogens, halophiles, Termococcales and Sulfolobales. FEMS Microbiology Reviews, 35:577-608.

Leininger, S.; Urich, T.; Schloter, M.; Schwark, L.; Qi, J.; Nicol, G. W.; Prosser, J. I.; Schuster, S. C.; Schleper, C. (2006). Archaea predominate among ammoniaoxidizing prokaryotes in soils. Nature, 442(7104):806-809.

Lovley, D. R.; Klug, M. J. (1983). Dioxide in the Sediments of a Hydrogen and Carbon and Acetogenesis from Methanol and Methylamines Methanogenesis from Eutrophic Lake. Applied and Environmental Microbiology 45(4):1310-1315.

Luque, R.; González-Domenech, C.M.; Llamas, I.; Quesada, E.; Béjar, V. (2012). Diversity of culturable halophilic archaea isolated from Rambla Salada, Murcia (Spain). Extremophiles, 16(2):205-213.

Lu, S.; Liu, X.; Ma, Z.; Liu, Q.; Wu, Z.; Zeng, X.; Shi, X.; Gu, Z. (2016). Vertical Segregation and Phylogenetic Characterization of Ammonia-Oxidizing Bacteria and Archaea in the Sediment of a Freshwater Aquaculture Pond. Frontiers in Microbiology, 6:1539.

Madigan, M.T.; Martinko, J.M.; Dunlap, P.V.; Clark, D.P. (2010). Microbiologia de Brock. $12^{a}$ Edição - Porto Alegre, Artmed.

Makarova, K. S.; Yutin, N.; Bell, S. D.; Koonin, E. V. (2010). Evolution of diverse cell division and vesicle formation systems in Archaea. Nature reviews. Microbiology, 8(10), 731-41.

Magrum, L. J.; Luehrsen, K. R.; Woese, C. R. (1978). Are extreme halophiles actually "bacteria"? Journal of Molecular Evolution, 11(1):1-8.

Maltseva, O.V.; Tsoi, T.V.; Quesen III, J.F.; Fukuda,M.; Tiedje, J.M. (1999). Degradation of anaerobic reductive dechlorination products of Arochlor 1242 by four aerobic bacteria. Biodegradation 10:363-371.

Melo, A. S. (2008). O que ganhamos ‘confundindo' riqueza de espécies e equabilidade em um índice de diversidade? Biota Neotropica, 8(3):21-27. 
Meng, J.; Xu, J.; Qin, D.; He, Y.; Xiao, X.; Wang, F. (2014). Genetic and functional properties of uncultivated MCG archaea assessed by metagenome and gene expression analyses. The ISME Journal, 8:650-659.

Muller, F.; Brissac, T.; Le Bris, N.; Felbeck, H.; Gros, O. (2010). First description of giant Archaea (Thaumarchaeota) associated with putative bacterial ectosymbionts in a sulfidic marine habitat. Environmental Microbiology, 12(8):23-71-2383.

Myers, N.; Mittermeier, R. A.; Mittermeier, C. G.; Fonseca, G. A. B.; Kent, J. (2000). Biodiversity hotspots for conservation priorities. Nature, 403:853-858.

Nunoura, T.; Takaki, Y.; Kakuta, J.; Nishi, S.; Sugahara, J.; Kazama, H.; Chee, G.J.; Hattori, M.; Kanai, A.; Atomi, H.; Takai, K.; Takami, H. (2011) Insights into the evolution of Archaea and eukaryotic protein modifier systems revealed by the genome of a novel archaeal group. Nucleic Acids Research, 39 (8): 3204-3223.

Nunoura, T.; Hirayama, H.; Takami, H.; Oida, H.; Nishi, S.; Shimamura, S.; Suzuki, Y.; Inagaki, F.; Takai, K.; Nealson, K.H.; Horikoshi, K. (2005) Genetic and functional properties of uncultivated thermophilic crenarchaeotes from a subsurface gold mine as revealed by analysis of genome fragments. Environmental Microbiology, 7(12):1967-1984.

Ng, S.Y.M.; Zolghadr, B.; Driessen, A.J.M.; Albers, S.V.; Jarrell, K.F. (2008). Cell surface structures of Archaea. Journal of Bacteriology., 190:6039-6047.

Offre, C.P.; Spang, A.; Schleper, C. (2013) Archaea in Biogeochemical cycles. Annual Reviews in Microbiology. 2013. 67:437-57

Olsen, G.J.; Lane, D.J.; Giovannoni, S.J.; Pace, N.R. (1986). Microbial ecology and evolution: a ribosomal RNA approach. Annual Reviews in Microbiology. 40:337--65

Oliveira, P.S.; Marquis, R.J. (2002). The cerrados of Brazil : ecology and natural history of a neotropical savanna. New York, Columbia University Press.

Oliveira-Filho, A. T. \& Ratter, J. A. (2002). Vegatation Physiognomies and Woody Flora of the Cerrado Biome. In: The Cerrados of Brazil - ecology and natural history of a neotropical savanna.

Owen, R.J. (2004). Bacterial taxonomics: finding the wood through the phylogenetic trees. Methods of Molecular Biology.;266:353-83.

Pace, N.R. (1997) "A molecular view of microbial diversity and the biosphere". Science, 276(5313): 734-40.

Park, H. D.; Wells, G. F.; Bae, H.; Criddle, C. S.; Francis, C. A. (2006). Occurrence of ammonia-oxidizing archaea in wastewater treatment plant bioreactors. Applied and Environmental Microbiology, 72(8): 5643-5647.

Parkes RJ, Webster G, Cragg BA, Weightman AJ, Newberry CJ, Ferdelman TG et al. (2005). Deep sub-seafloor prokaryotes stimulated at interfaces over geological time. Nature 436: 390-394 
Pester, M.; Schleper, C.; Wagner, M. (2011) The Thaumarchaeota: an emerging view of their phylogeny and ecophysiology. Current Opinion in Microbiology., 14:1-7.

Pester, M*; Rattei, T.; Flechl. S.; Gröngröft, A.; Richter, A.; Overmann, J.; ReinholdHurek, B.; Loy, A.; Wagner, M. (2012) .amoA-based consensus phylogeny of ammonia-oxidizing archaea and deep sequencing of amo $A$ genes from soils of four different geographic regionse. Environmental Microbiology.14(2), 525-539

Peet, R. K. (1974). The measurement of species diversity. Annual Review of Ecology and Systematics, 5:285-307.

Pikuta, E.V.; Marsic, D.; Itoh, T.; Bej, A.K.; Tang, J.; Withman, W.B.; Ng, J.D.; Garriott, O.K.; Hoover, R.B. (2007). Thermococcus thioreducens sp. Nov., a novel hyperthermophilic, obligately súlfur-reducing archaeon from a deep-sea hydrothermal vent. International Journal of Systematic and Evolutionary Microbiology, 57:1612-1618.

Pouliot, J.; Galand, P. E.; Lovejoy, C.; et al. (2009). Vertical structure of archaeal communities and the distribution of ammonia monooxygenase A gene variants in two meromictic High Arctic lakes. Environmental Microbiology. 11 :687-99.

Preston, C.M.; Wu, K.Y Molinski, T.F.; DeLong, E.F. (1996) A psychrophilic crenarchaeon inhabits a marine sponge: Cenarchaeum symbiosum gen. nov., sp. nov. Proc. Natl. Acad. Sci. USA, 93:6241-6246.

Probst, A. J.; Auerbach, A.K.; Moissl-Eichinger, C. (2013) Archaea on human skin. PLoS One.8(6):e65388.

Prosser, J.I. \& Nicol, G. (2008). Relative contributions of archaea and bacteria to aerobic ammonia oxidation in the environment. Environmental Microbiology, 10(11):2931-2941.

Quirino, B. F.; Pappas, G. J.; Tagliaferro, A. C.; Collevatti, R. G.; Neto, E. L.; da Silva, M. R. S. S.; Bustamante, M. M. C.; Krüger, R. H. 2009. Molecular phylogenetic diversity of bacteria associated with soil of the savanna-like Cerrado vegetation. Microbiological Research, 164(1):59-70.

Rappé, M. S.; Giovannoni, S. J. (2003). The uncultured microbial majority. Annual Reviews of Microbiology, 57:369-394.

Riley, P.S.; Weaver R.E. (1975). Recognition of Pseudomonas pickettii in the clinical laboratory: biochemical characterization of 62 strains. Journal of Clinical Microbiology 1(1):61-64.

Rinke, C.; Schwientek, P.; Sczyrba, A.; Ivanova, N. N.; Anderson, I. J.; Cheng, J. F.; Darling, A.; Malfatti, S.; Swan, B. K.; Gies, E. A.; Dodsworth, J. A.; Hedlund, B. P.; Tsiamis, G.; Sievert, S. M.; Liu, W. T.; Eisen, J. A.; Hallam, S. J.; Kyrpides, N. C.; Stepanauskas, R. Rubin, E. M.; Hugenholtz, P.; Woyke, T. (2013). Insights into the phylogeny and coding potential of microbial dark matter. Nature, 499(7459):431-437.

Robertson, C. E.; Harris, J. K.; Spear, J. R.; Pace, N. R. (2005). Phylogenetic diversity and ecology of environmental Archaea. Current Opinion in Microbiology, 8(6):638-642. 
Rodrigues, T.; Catão, E.; Bustamante, M. M.; Quirino, B. F.; Kruger, R. H.; Kyaw, C. M. (2014). Seasonal effects in a lake sediment archaeal community of the Brazilian Savanna. Archaea. Jul 20;2014:957145. doi: 10.1155/2014/957145. eCollection 2014.

Rosselló-Mora, R. \& Amann, R. (2001). The species concept for prokaryotes. FEMS Microbiology Reviews, 25:39-67.

Sauder, L. A.; Engel, K.; Stearns, J. C.; Masella, A. P.; Pawliszyn, R.; Neufeld, J. D. (2011). Aquarium nitrification revisited: Thaumarchaeota are the dominant ammonia oxidizers in freshwater aquarium biofilters. PloS one, 6(8): e23281.

Schleifer, K.H. (2009). "Classification of Bacteria and Archaea: past, present and future." Systematic and Applied Microbiology 32(8): 533-542.

Schleper, C.; Jurgens, G.; Jonuscheit, M. 2005. Genomic studies of uncultivated archaea. Nature Reviews in Microbiolology, 3:479-488.

Schleper, C. (2007). Diversity of uncultivated Archaea: perspectives from microbial ecology and metagenomics. In: Archaea: Evolution, Physiology and Molecular Biology. Blackwell Publishing, 438p.

Schloss, P. D. \& Handelsman, J. (2004). Status of the microbial census. Microbiology and Molecular Biology Reviews, 68(4):686-691.

Schloss, P. D.; Westcott, S. L.; Ryabin, T.; Hall, J. R.; Hartmann, M.; Hollister, E. B.; Lesniewski, R. A.; Oakley, B. B.; Parks, D. H.; Robinson, C. J.; Sahl, J. W.; Stres, B.; Thallinger, G. G.; Van Horn, D. J.; Weber, C. F. (2009). Introducing mothur: Open-source, platform-independent, community-supported software for describing and comparing microbial communities. Applied and Environmental Microbiology, 75(23):7537-7541.

Schopf, S.; Wanner, G.; Reinhard, R.; Reinhard, W. (2008). An archaeal bi-species biofilm formed by Pyrococcus furiosus and Methanopyrus kandleri. Archives in Microbiology. 190:371

Simon, H.M.; Jahn, C.E.; Bergerud, L.T.; Sligerud, K.; Weimer, P.J.; Willis, D.K. (2005) . Cultivation of Mesophilic Soil Crenarchaeotes in Enrichment Cultures from Plant Roots. Applied and Environmental Microbiology, 71(8):4751-4760.

Silva, M. R. S. S. 2012. Diversidade de comunidades bacterianas de solo de Cerrado em resposta a diferentes alterações dos ecossistemas. Tese de doutorado, Departamento de Ecologia do Instituto de Ciências Biológicas, Universidade de Brasília.

Sowers, K.R.; Baron, S.F.; Ferry, J.G. (1984). Methanosarcina Acetivorans Sp. Nov., an Acetotrophic Methane-Producing Bacterium Isolated from Marine Sediments. Applied and Environmental Microbiology 47.5: 971-978.

Sogin, M.L.; Morrison, H.G.; Huber, J.A.; Welch, D.M.; Huse, S.M.; Neal, P.R.; Arrieta, J.M.; Hernd, G.J. (2006). Microbial diversity in the deep sea and the underexplored 'rare biosphere'. Proceedings of the National Academy of Sciences of USA, 103(32): 12115-12120. 
Spang, A.; Hatzenpichler, R.; Brochier-Armanet, C.; Rattei, T.; Tischler, P.; Spieck, E.; Streit, W.; Stahl, D. A.; Wagner, M.; Schleper, C. (2010). Distinct gene set in two different lineages of ammonia-oxidizing archaea supports the phylum Thaumarchaeota. Trends in Microbiology, 18(8):331-340.

Spang, A.; Poehlein, A.; Offre, P.; Zumbrägel, S.; Haider, S.; Rychlik, N.; Nowka, B.; Schmeisser, C.; Lebedeva, E. V.; Rattei, T.; Böhm, C.; Schmid, M.; Galushko, A.; Hatzenpichler, R.; Weinmaier, T.; Daniel, R.; Schleper, C.; Spieck, E.; Streit, W.; Wagner, M. (2012). The genome of the ammonia-oxidizing Candidatus Nitrososphaera gargensis: insights into metabolic versatility and environmental adaptations. Environmental Microbiology, 14(12):3122-3145.

Spang, A.; Martijn, J.; Saw, J. H..;Lind, A. E. ; Guy, L.; Ettema, T. J. (2013). Close encounters of the third domain: the emerging genomic view of archaeal diversity and evolution. Archaea. Volume 2013, Article ID 202358.

Spang, A.; Saw, J. H. ; Jørgensen, S. L.; Zaremba-Niedzwiedzka, K. ; Martijn, J. ; Lind, A. E.; Eijk, R. V.; Schleper, C.; Guy, L.; Ettema, T. J.G. (2015) Complex archaea that bridge the gap between prokaryotes and eukaryotes. Nature. 521(7551): 173179.

Stackebrandt, E. \& Goebel, B. M. (1994). Taxonomic Note: A Place for DNA-DNA Reassociation and 16s rRNA Sequence Analysis in the Present Species Definition in Bacteriology. International Journal of Systematic Bacteriology, 44(4):846849.

Stackebrandt, E.; Frederiksen, W.; Garrity, G. M.; Grimont, A. D.; Ka, P.; Maiden, M. C. J.; Nesme, X.; Swings, J.; Tru, H. G.; Ward, A. C.; Whitman, W. B. 2002. Report of the ad hoc committee for the re-evaluation of the species definition in bacteriology. International Journal of Systematic and Evolutionary Microbiology, 52:1043-1047.

Staley, J.T. \& Konopka, A. (1985). Measurement of in situ activities of nonphotosynthetic microorganisms in aquatic and terrestrial habitats. Annual Reviews of Microbiology, 39:321-346.

Stempfhuber, B.; Engel, M.; Fischer D.; Nesjovic-Prit, G.; Wubet, T.; Schöning, I.; Gubry-Rangin, C.; Kublik, S.; Schloter-Hai, B.; Rattei, T.; Welzl, G.; Nicol, G.W.; Schrumpf, M.; Buscot, F.; Prosser, J.I.; Schloter, M. (2014) "PH as a driver for ammonia-oxidizing archaea in forest soils”. Soil Microbiology.

Stetter, K.O.; Winter, J.: Hartlieb, R. (1980). DNA dependent RNA polymerase of the archaebacterium Methanobacterium thermoautotrophicum. Zbl. Bakt. Hyg., I Abt.Orig.C1:201-21

Streit, W.F. \& Schmitz, R.A. (2004). Metagenomics - the key to the uncultured microbes. Current Opinion in Microbiology, 7(5): 492-498.

Stieglmeier, M.; Klingl, A.; Alves, R. J. E.; Rittmann, S. K. R.; Melcher, M.; Leisch, N.; Schleper, C. (2014). Nitrososphaera viennensis gen. nov., sp. nov., an aerobic and mesophilic, ammonia-oxidizing archaeon from soil and a member of the 
archaeal phylum Thaumarchaeota. International Journal of Systematic and Evolutionary Microbiology, 64:2738-2752.

Sturm, S.; Schönefeld, V.; Zillig, W.; Janekovic, D. Stetter, K.O. (1980). Structure and function of the DNA dependent RNA polymerase of the archaebacterium Thermoplasma acidophilum. Zentralblatt für Bakteriologie 1 Abt Originale B Hygiene, C1:12-25.

Straskraba, M.; Tundisi, J.G. Diretrizes para o gerenciamento de lagos Gerenciamento da qualidade da água de represas - vol 9 pág 280. São CarlosSP.

Swanson, C. A.; Sliwinski, M. K. (2013). One-dimensional TRFLP-SSCP is an effective DNA fingerprinting strategy for soil Archaea that is able to simultaneously differentiate broad taxonomic clades based on terminal fragment length polymorphisms and closely related sequences based on single stranded conformation polymorphisms. Journal of Microbiological Methods, 94(3):317324.

Takai, K.; Moser, D.P.; DeFlaun, M.; Onsott, T.C.; Fredrickson, J.K. (2001).Archaeal Diversity in Waters from Deep South African Gold Mines. Applied and Environmental Microbiology, 67(12): 5750-5760.

Tamura, K.; Peterson, D.; Peterson, N.; Stecher, G.; Nei, M.; Kumar, S. (2011). MEGA5: Molecular evolutionary genetics analyses using maximum likelihood, evolutionary distance and maximum parsimony methods. Molecular Biology and Evolution, 28: 2731-2739

Thomaz, S.M.; Pereira, G.; Pagioro T.A. (2001). Microbial respiration and chemical composition of different sediment fractions in waterbodies of the upper Paraná river floodpain, Brazil. Brazilian Journal of Biology 61(2): 277-286

Torres, I. C., Inglett, K. S., \& Reddy, K. R. (2010). Heterotrophic microbial activity in lake sediments: effects of organic electron donors. Biogeochemistry, 104(1-3), 165-181. doi:10.1007/s10533-010-9494-6

Torsvik, V. \& Øvreas, L. 2002. Microbial diversity and function in soil: from genes to ecosystems. Current Opinion in Microbiology, 5(3):240-245.

Torsvik, V.; Øvreas, L. (2006)ra. Microbial diversity and phylogeny in soil. In: Modern Soil Microbiology. (Elsas, J.D.; Jansson, J.K.; Trevors, J. T., eds) USA: CRC Press, 2a edição. Capítulo 2, p. 23-52.

Tourna, M.; Stieglmeier, M.; Spang, A.; Könneke, M.; Schintlmeister, A.; Urich, T.; Engel, M.; Scloter, M.; Wagner, M.; Richter, A.; Schleper, C. (2011). Nitrososphaera viennensis, an ammonia oxidizing archaeon from soil. Proceedings of the National Academy of Sciences of USA, 108(20):8420-8425.

Tran Van, V.; Berger, O.; Ngo Ke, S.; Balandreau, J.; Heulin, T. (2000). Repeated beneficial effects of rice inoculation with a strain of Burkholderia vietnamiensis on early and late yield components in low fertility sulphate acid soils. Plant Soil 218:273-284. 
Tsao, J.H.; Kaneshiro, S.M.; Yu, S.S.; Clark, D.S. (1994). Continuous culture of Methanococcus jannaschii, an extremely thermophilic methanogen. Biotechnology and Bioengineering, 43: 258-261.

Tuomisto, H. (2010) "A diversity of beta diversities: straightening up a concept gone awry. Part 1. Degining beta diversity as a function of alfa and gamma diversity". Ecography, 22(1): 2-22.

Vetriani C, Jannasch HW, MacGregor BJ, Stahl DA, Reysenbach AL. (1999). Population structure and phylogenetic characterization of marine benthic Archaea in deep-sea sediments. Applied and Environmental Microbiology. 65:43754384.

Viallard, V.; Poirier, I.; Cournoyer, B.; Haurat, J.; Wiebkin, S.; Ophel-Keller, K.; Balandreau, J.(1998). Burkholderia graminis sp. nov., a rhizospheric Burkholderia species, and reassessment of [Pseudomonas] phenazinium, [Pseudomonas] pyrrocinia, [Pseudomonas] glathei as Burkholderia. Int. J. Syst. Bacteriol. 48:549-563

Vial, L.; Groleau, M.C.; Dekimpe, V.; Déziel, E. (2007). Burkholderia diversity and versatility: An inventory of the extracellular products. $\mathbf{J}$ Microbiol Biotechnol.;17:1407-29

Vissers, E. W.; Bodelier, P. L. E.; Muyzer, G.; Laanbroek, H. J. (2009). A nested PCR approach for improved recovery of archaeal 16S rRNA gene fragments from freshwater samples. FEMS Microbiology Letters, 298(2):193-198.

Vissers, E.W.; Blaga, C.I.; Bobelier, P.L.E.; Muyzer, G.; Scheleper, C.; Damste, J.S.S.; Tourna, M.; Laanbroeki, H.J. (2013). Seasonal and vertical distribution of putative ammoniaoxidizing thaumarchaeotal communities in an oligotrophic lake. FEMS Microbiol Ecol 83; 515-526

Walter, B.M.T.; Carvalho, A.M. de; Ribeiro, J.F. O conceito de savana e de seu componente Cerrado, In: Cerrado: ecologia e flora - Volume 1. (SANO, S.M.; ALMEIDA, S.P.; RIBEIRO, J.F.; eds) Embrapa Cerrados, Brasília, DF: Embrapa Informação Tecnológica, (2008), capítulo 1, 21-45.

Watve, M.; Shejval, V.; Sonawane, C.; Rahalkar, M.; Matapurkar, A.; Shouche,; Patole, M.; Phadnis, N.; Champhenkar, A.; Damle, K.; Karandikar, S.; Kshirsagar, V.; Jog, M. (2000). The 'K' selected oligophilic bacteria; a key to uncultured diversity? Current Science, 78:1535:1542.

Weidler, G. W.; Dornmayr-Pfaffenhuemer, M.; Gerbl, F. W.; Heinen, W.; Stan-Lotter, H. 2007. Communities of archaea and bacteria in a subsurface radioactive thermal spring in the Austrian Central Alps, and evidence of ammonia-oxidizing Crenarchaeota. Applied and Environmental Microbiology, 73(1):259-270.

Wetzel, R.G. (2001). Sediments and Microflora. Limnology Lake and River Ecosystems. 3a Edição - Elsevier, San Diego, p. 631-664.

Wintzingerode, F.; Göbel, U.; Stackebrandt, E.; (1997) "Determination of microbial diversity in environmental samples: pitfalls of PCR-based rRNA analysis". FEMS Microbiology Reviews, 21(3): 213-229 
Wheelis,M. L.; Kandler, O.; Woese, C. R (1992). On the nature of global classification. Proceedings of the National Academy of Sciences of USA., Vol. 89, pp. 29302934.

Whittaker, R.H. (1969) New concepts of kingdoms of organisms. Science, 163:150160.

Woese, C. R.; Fox, G. E. (1977). Phylogenetic structure of the prokaryotic domain: the primary kingdoms. Proceedings of the National Academy of Sciences of USA, 74(11):5088-5090.

Woese, C. R.; Magrum, L. J.; Fox, G. E. (1978). Archaebacteria. Journal of Molecular Evolution, 11(3): 245-251.

Woese, C. R.; Kandlert, O.; Wheelis, M. L. (1990). Towards a natural system of organisms: Proposal for the domains. Proceedings of the National Academy of Science of USA, 87:4576-4579.

Wu, Y. \& Conrad, R. (2014). Thaumarchaeota in acidic red soil microcosms. FEMS Microbiology Ecology, 89:127-134.

Wuchter, C.; Abbas, B.; Coolen, M. J. L.; Herfort, L.; van Bleijswijk, J.; Timmers, P.; Strous, M.; Teira, E.; Herndl, G. J.; Middelburg, J. J.; Schouten, S.; Damsté, J. S. S. (2006). Archaeal nitrification in the ocean. Proceedings of the National Academy of Science of USA, 103(33):12317-12322.

Xu, M.; Schnorr, J.; Keibler, B.; Simon, H. M. 2012. Comparative analysis of 16S rRNA and amoA genes from archaea selected with organic and inorganic amendments in enrichment culture. Applied and Environmental Microbiology, 78(7):2137-2146.

Yang, K.; Zhang, L. (2008). Performance comparison between $k$-tuple distance and four model-based distances in phylogenetic tree reconstruction. Nucleic Acids Research, 36(5), e33.

Ying, J. Y.; Zhang, L. M.; He, J. Z. (2010). Putative ammonia-oxidizing bacteria and archaea in an acidic red soil with different land utilization patterns. Environmental Microbiology Reports, 2(2):304-312.

You, J.; Das, A.; Dolan, E. M.; Hu, Z. 2009. Ammonia-oxidizing archaea involved in nitrogen removal. Water research, 43(7):1801-1807.

Zardo, D.C.; Maas, G.C.B.; Baia, S.; Weber, O.L.S. (2011) Característircas físicoquímicas e microbiológicas do sedimento da microbacia Samamnaia - MT, Brasil. Revista Ciências do Ambiente On-Line, 7:2.

Zeikus, J.G. (1977). The biology of methanogenic bacteria. Bacteriol. Rev., 41:514-541

Zengler, K.; Toledo, G.; Rappé, M.; Elkins, J.; Mathur, E. J.; Short, J. M.; Keller, M. (2002). Cultivating the uncultured. Proceedings of the National Academy of Science of USA. 99(24):15681-15686.

Zillig, W., Stetter, K.O.; Janekovic, D. (1979). DNA dependent RNA polymerase from the archaebacterium Sulfolobus acidocaldarius. Eur. J. Biochem., 96:597-604 
Zhalnina, K.; de Quadros, P. D.; Camargo, F. A. O.; Triplett, E. W. (2012). Drivers of archaeal ammonia-oxidizing communities in soil. Frontiers in microbiology, 3(210):1

Zhu, D.-L., Sun, C., \& He, H. (2012). Detection Methanogens in Newly Settled Sediments from Xuanwu Lake in Nanjing, China. Current microbiology

Zuckerkandl, E.; Pauling, L. (1965) Molecules as documents of evolutionary history. Journal of Theoretical Biology, 8(2): 357-366. 